NBER WORKING PAPER SERIES

\title{
WHO IS EXPOSED TO GAS PRICES? HOW GASOLINE PRICES AFFECT AUTOMOBILE MANUFACTURERS AND DEALERSHIPS
}

\author{
Meghan R. Busse \\ Christopher R. Knittel \\ Florian Zettelmeyer \\ Working Paper 18610 \\ http://www.nber.org/papers/w18610
}

\author{
NATIONAL BUREAU OF ECONOMIC RESEARCH \\ 1050 Massachusetts Avenue \\ Cambridge, MA 02138 \\ December 2012
}

Christopher Knittel is currently funded by a Ford Motor Company MIT Alliance grant to run experiments in a variety of Ford dealerships designed to assess whether more information about fuel consumption and fuel costs changes consumer behavior. Meghan Busse and Florian Zettelmeyer gratefully acknowledge the support of NSF grants SES-0550508 and SES-0550911. The views expressed herein are those of the authors and do not necessarily reflect the views of the National Bureau of Economic Research.

NBER working papers are circulated for discussion and comment purposes. They have not been peerreviewed or been subject to the review by the NBER Board of Directors that accompanies official NBER publications.

(C) 2012 by Meghan R. Busse, Christopher R. Knittel, and Florian Zettelmeyer. All rights reserved. Short sections of text, not to exceed two paragraphs, may be quoted without explicit permission provided that full credit, including $\odot$ notice, is given to the source. 
Who is Exposed to Gas Prices? How Gasoline Prices Affect Automobile Manufacturers and Dealerships

Meghan R. Busse, Christopher R. Knittel, and Florian Zettelmeyer

NBER Working Paper No. 18610

December 2012

JEL No. L1,L2,L9,Q4

\section{ABSTRACT}

Many consumers are keenly aware of gasoline prices, and consumer responses to gasoline prices have been well studied. In this paper, by contrast, we investigate how gasoline prices affect the automobile industry: manufacturers and dealerships. We estimate how changes in gasoline prices affect equilibrium prices and sales of both new and used vehicles of different fuel economies. We investigate the implications of these effects for individual auto manufacturers, taking into account differences in manufacturers' vehicle portfolios. We also investigate effects on manufacturers' affiliated dealership networks, including effects implied by the changes in used vehicle market outcomes.

Meghan R. Busse

Northwestern University

Kellogg School of Management

Management \& Strategy, Sixth Floor

2001 Sheridan Road

Evanston, IL 60208

and NBER

m-busse@kellogg.northwestern.edu

Christopher R. Knittel

MIT Sloan School of Management

100 Main Street, E62-513

Cambridge, MA 02142

and NBER

knittel@mit.edu
Florian Zettelmeyer

Northwestern University

Kellogg School of Management

Marketing Department, Fourth Floor

2001 Sheridan Road

Evanston, IL 60208

and NBER

f-zettelmeyer@kellogg.northwestern.edu 
You know what I'd rather have them do-this will make my Republican friends puke-as gas is going to go down here now, we ought to just slap a 50-cent or a dollar tax on a gallon of gas

Dan Akerson, CEO of General Motors, Detroit News, June 7, 2011

\section{Introduction}

On November 19, 2008, the CEOs of Chrysler, Ford, and General Motors appeared before the U.S. Senate to ask for a financial bailout package to prevent their companies from going bankrupt. The event was a dramatic and public admission that the U.S. auto industry was in a very precarious financial position. Although there were presumably a large number of factors that led to these events, two seem particularly likely to have had first order effects.

One is the financial crisis in the U.S., a crisis that had been building throughout the mid-2000s because of risky practices in the subprime mortgage market, but which burst into a full-blown crisis of the financial system in mid-September 2008 with the collapse of Lehman Brothers investment bank and the proposal of a $\$ 700$ billion emergency bailout by Treasury Secretary Henry Paulson and Fed Chariman Ben Bernanke. The threat of a looming recession depressed orders for durable goods such as vehicles almost immediately. ${ }^{1}$

A second factor, which had also been operating over several years, had put U.S. auto manufacturers into a strained position even before the financial crisis. This factor is rising gasoline prices. The average price of gasoline in the U.S. hovered steadily between about $\$ 1$ and $\$ 1.50$ per gallon throughout the late 1990s and early 2000s, as shown in Figure 1. Then, in early 2005, the national average price of gasoline passed $\$ 2$ per gallon, and began to be much more variable, repeatedly increasing or decreasing by $\$ 0.50$ to $\$ 1$ within several months. Throughout this period, the overall trend was increasing, and the national average gasoline price finally reached $\$ 4$ per gallon in mid-2008.

While the auto industry bailout might be the most public evidence that fluctuating gasoline prices create risks for auto manufacturers, there is less well-known, but more directly related, evidence that suggests this even more strongly. Recently, various automobile industry insiders have begun to argue that a minimum gasoline price would benefit the industry by encouraging consumers to buy high-MPG cars more consistently. One supporter is Michael Jackson, the CEO of Autonation, the largest dealership group in the U.S., who called a gasoline price floor of $\$ 4$ per gallon "a good start." 2 Another is Keith Crain, the publisher and editorial director of Automotive

\footnotetext{
${ }^{1}$ Jeff Bater and Brian Blackstone, "Data Indicate Faltering Demand," Wall Street Journal, November 26, 2008; Kelly Evans and Sudeep Reddy, "Capital Spending Continues to Fall," Wall Street Journal, January 30, 2009; Richard Truett, "September was awful, and 2009 looks ugly," Automotive News, October 7, 2008.

2 "Tax My Products, Please," Wall Street Journal, March 17, 2009
} 
News, a leading trade journal, who argued in a 2009 editorial for a tax that would set a minimum price of $\$ 3.50 .^{3}$ Finally, Alan Mulally, the CEO of Ford, has supported such a tax obliquely, suggesting that it would be more effective than CAFE standards, ${ }^{4}$ and arguing for an "integrated energy policy" that would "involve the consumer." 5 These arguments all suggest that the problems created for auto manufacturers by variability in gasoline prices - such as difficulties in long-run vehicle planning - are large enough that manufacturers would actually prefer high gasoline prices to variable gasoline prices. ${ }^{6}$

The aim of this paper is to understand how changes in gasoline prices affect vehicle markets, and in particular to understand the implications of these effect for automobile manufacturers and dealers. We begin by estimating the effect of gasoline prices on the prices and sales of vehicles and find (as did Li, Timmins, and von Haefen (2009) and Busse, Knittel, and Zettelmeyer (forthcoming)) that the effect of gasoline prices varies for vehicles according to the vehicle's fuel economy. In this paper, we add to these previous results by showing how changing gasoline prices affect individual vehicle buyer's choices relative to their past vehicle choices. Second, we show that gasoline prices have very different effects on new vehicle prices and sales and on used vehicle prices and sales. We argue that the most plausible reason for this difference is differences in the market structure of the industry that supplies new vehicles (auto manufacturers) and the industry that supplies used vehicles (individual owners and wholesale auctions). Third, we show that, because manufacturers differ substantially in the mix of vehicles that they offer, manufacturers of different nameplates - and their affiliated dealers - are likely to be affected very differently by changes in gasoline prices.

This paper proceeds as follows. We begin by describing in the next section the data we will use for the analysis in this paper. In Section 3 we delineate the contribution of this paper relative to related papers. In Section 4 we investigate the effect of gasoline price changes on individual consumers' choices of fuel economy relative to their past choices. In Sections 5 and 6 we estimate the effect of gasoline prices on the equilibrium market shares, sales, and prices of new and used vehicles, respectively. Section 7 investigates the implication of our estimated gasoline price effects for the revenues of individual automobile manufacturers and for the net revenues of their associated dealer networks. Section 8 investigates the robustness of our empirical results by allowing the effects to vary by gasoline price levels and trends, and by classifying vehicles according to their segment rather than by their fuel economy. Section 9 offers some concluding remarks.

\footnotetext{
${ }^{3}$ Keith Crain, "After 34 years, CAFE still doesn't work," Automotive News, May 25, 2009

${ }^{4}$ Richard Truett, "Mulally: Higher gas taxes would conserve fuel," Automotive News, August 8, 2007

5 "Tax My Products, Please," Wall Street Journal, March 17, 2009

${ }^{6}$ The 2006-2008 run-up in gasoline prices coincided with the Ford F-150 pickup truck losing its decades-long position as the best-selling vehicle in the U.S. to the Honda Civic, a very different vehicle.
} 


\section{Data}

The analysis in the paper makes use of several different types of data. The primary data contain information on automobile transactions occurring between January 1, 1998 and June 30, 2008 from a sample of about $20 \%$ of all new car dealerships in the U.S. A major market research firm collected the data, which include every new vehicle and used vehicle transaction at the dealers in the sample during the sample period. For each transaction we observe the precise vehicle that is purchased, the price the customer paid for the vehicle, (Census-based) demographic information on the customer, and detailed information on the vehicle that was traded in, if any. We describe the variables used in each specification in more detail later in the paper.

We augment these transaction data with information about gasoline prices and about the fuel economy of different vehicle models. We use data from the Energy Information Administration on weekly regional gasoline prices. The EIA collects its data by telephoning about 900 retail gasoline outlets every Monday. We use data on the price of regular gasoline, which is gasoline with an octane rating of at least 85 but less than 88 . The data are weighted by sales and delivery volume to create average prices for different levels of geographic aggregation. The EIA uses a regional classification that divides the U.S. into seven areas called PADDs (Petroleum Administration for Defense Districts): New England, Central Atlantic, Lower Atlantic, Midwest, Gulf Coast, Rocky Mountain, and West Coast. ${ }^{7}$ In all the specifications we estimate in this paper, gasoline price is measured at either the PADD-week or PADD-month level.

There is fairly substantial intertemporal variation in gasoline prices in our sample period. In Figure 1, we graph the weekly national average gasoline price in our sample. The national average is as low as $\$ 1$ early in the sample, and rises to $\$ 4$ in the later parts of the sample. There is also variation by PADD. In Figure 2 we graph gasoline prices for West Coast (PADD 5, which typically has the highest prices), Gulf Coast (PADD 3, which typically has the lowest prices), and Rocky Mountain (PADD 4, which is an example of a medium-priced area). As can be seen from this graph, the price difference between areas changes over time.

We measure the fuel economy of each vehicle model with the Environmental Protection Agency (EPA)'s "Combined Fuel Economy" which is a weighted geometric average of the EPA Highway (45\%) and City (55\%) Vehicle Mileage. In 2008, the EPA changed the formula that it uses to calculate MPG in order to make the official rating better represent what a typical driver would experience. Using conversion formulas available from the EPA, we are able to translate the MPG

\footnotetext{
${ }^{7}$ Technically, the EIA divides the country into five Petroleum Administration for Defense Districts (PADDs). Price data for the East Coast PADD is reported separately by three subdistricts (New England, Central Atlantic, and Lower Atlantic). These three subdistricts plus the four remaining districts define the geographic granularity of the gasoline price data we use.
} 
Figure 1: Weekly average gasoline prices (national)

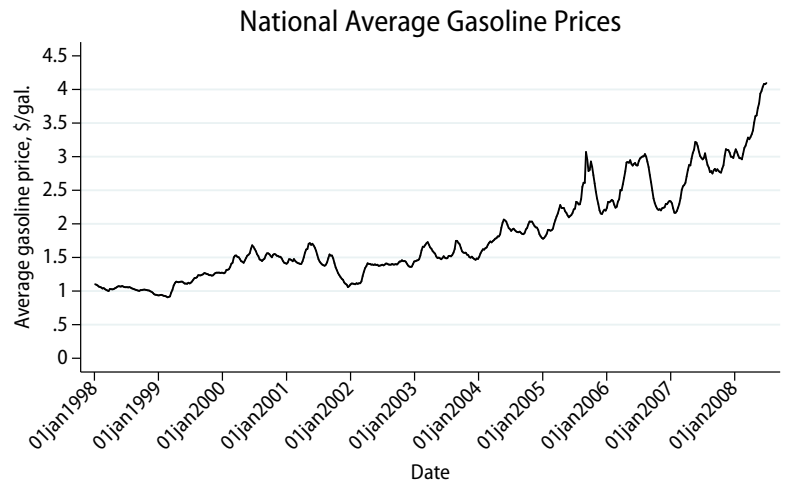

Figure 2: Weekly average gasoline prices (by area)

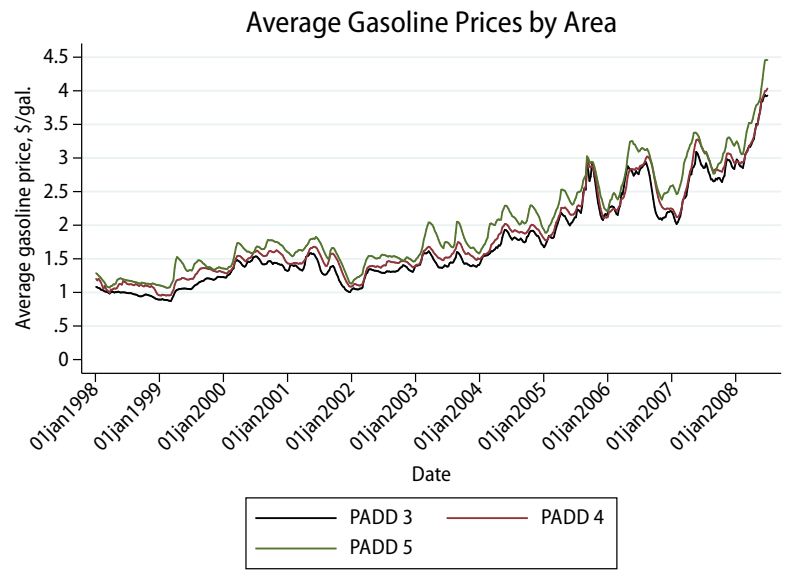


rating for pre-2008 model year cars to a rating in the 2008 system, and it is this version of the ratings we use in this paper.

In most results in the paper, we use a $25 \%$ random sample of all transactions as our final estimation sample. $^{8}$ Our estimation sample, which includes transaction, gasoline price, and MPG information, contains 4,156,663 new vehicle transaction and 2,923,323 used vehicle transactions. Table 16 presents summary statistics separately by new and used vehicle transactions.

\section{Previous literature}

Several recent papers have estimated how responsive vehicle buyers are to changes in gasoline prices. These papers have used various approaches and data from different time periods and countries. They all have found that consumers are responsive to some extent either in the prices they are willing to pay or in the kinds of vehicles they choose to buy, or on both dimensions. Klier and Linn (2010) and Li, Timmins, and von Haefen (2009) estimate the effect of gasoline prices on sales of vehicles of differing fuel economies. Sallee, West, and Fan (2009), and Verboven (2002) find that car buyers come close to fully adjusting their willingness-to-pay in response to gasoline prices. Allcott and Wozny (2011) find that consumers are moderate in their adjustment to gasoline prices, while Kahn (1986) finds the least adjustment, among recent papers on the topic, by consumers to gasoline prices.

The paper most closely related to this paper is Busse, Knittel, and Zettelmeyer (forthcoming), although the focus in this paper is very different. Busse, Knittel, and Zettelmeyer focuses on consumer behavior; specifically how consumers trade off the upfront prices of vehicles against their future gasoline costs. This paper, in contrast, focuses on firms; specifically on market structure and on firm profitability in the face of changes in gasoline prices. While both this paper and Busse, Knittel, and Zettelmeyer estimate how new and used vehicle prices and quantities respond to changes in gasoline prices, Busse, Knittel, and Zettelmeyer use their estimates to estimate the implied discount rates that consumers use when making vehicle purchase decisions. This paper, in contrast, focuses on the effect that changes in gasoline prices have on revenues and firm profitability and on how this effect varies across automobile manufacturers and across their affiliated dealer networks.

To estimate the impact on manufacturer and dealer profitability, we bring in both new data and new empirical results. While Busse, Knittel, and Zettelmeyer focuses only on retail price effects, this paper focuses on gasoline price effects throughout the supply chain. Specifically, here

\footnotetext{
${ }^{8}$ The $25 \%$ sample is necessary to allow for estimation of specifications with multiple sets of high-dimensional fixed effects, including fixed effect interactions, that we use later in the paper.
} 
we also estimate how wholesale prices and dealer margins change when gasoline prices change. In addition, we investigate whether the effect of gasoline prices differs when gasoline price are high or low, or when they have been rising or falling. Finally, we use a much larger estimation sample (approximately 2.5 times larger).

\section{Consumer response to gasoline prices}

In this section, we will exploit one of the unique features of our data (among papers addressing this topic) in order to estimate the effect of gasoline prices on consumer choices. In our data, we observe transactions for individual vehicles, including what vehicle - if any - was traded in as part of the transaction. This means that for the approximately $40 \%$ of new and used vehicle transactions that involve a trade-in, we can see what a customer purchases compared to what that same customer purchased at some point in the past. We can use this information to estimate whether consumers buy higher MPG vehicles relative to their trade-in vehicles when gasoline prices are high than when they are low.

We do this by estimating the following regression.

$$
\mathrm{MPG}_{i r j l t}=\beta_{0}+\beta_{1} \text { GasolinePrice }_{a t}+\beta_{2} \text { Demog }_{i}+\beta_{3} \text { PurchaseTiming }_{j t}+\delta_{l}+\tau_{r T}+\mu_{r t}+\xi_{i j k t}
$$

$M P G_{i r j l t}$ is the MPG of vehicle $j$ bought by customer $i$ in region $r$ at date $t$ using trade-in vehicle $l$. The key coefficient we wish to estimate is $\beta_{1}$, the effect of GasolinePrice in PADD $a$ at date $t$ on the MPG of the vehicle purchased by customer $i$. We include as covariates the demographic characteristics of customer $i$ 's Census block group $\left(\mathbf{D e m o g}_{i}\right)$ from the 2000 Census. $\operatorname{Demog}_{i}$ contains information on the income, house value and ownership, household size, vehicles per household, education, occupation, average travel time to work, English proficiency, and race of buyers. We also include PurchaseTiming ${ }_{i t}$, a vector of indicators for whether the transaction occurred on a weekend (Saturday or Sunday); occurred during the last five days of the month; or occurred during the last five days of the year. These are times in which dealers may have "stair step incentive" targets that make them particularly eager to make sales. In addition, we allow region-specific year $\left(\tau_{r T}\right)$ and region-specific month-of-year $\left(\mu_{r t}\right)$ fixed effects. There are 34 regions in the U.S., defined by the firm that collects the transaction data according to its understanding of regional automobile markets. ${ }^{9}$ Using region-specific time fixed effects allows for secular or seasonal

\footnotetext{
${ }^{9}$ The 34 regions are: Baltimore/Washington, Charlotte, Cincinnati, Cleveland, Colorado, Columbus, Dakotas, Detroit, Georgia, Gulf, Hawaii, Illinois/Indiana, Indianapolis, Kansas City, Miami, Minneapolis, Missouri, Nevada, New England, New York, Norfolk/Virginia Beach, Northern California, Oklahoma, Orlando, Pennsylvania, Phoenix, Pittsburgh, San Antonio, Seattle/Portland, South Texas, Southern California, Tampa, Tennessee, and Texas. Although the regions are sometimes named after cities and sometimes after states, they represent a complete division
} 
differences in preferences for high- vs. low-MPG vehicles, and allows these intertemporal differences to differ by region of the country.

The most important covariate in the specification is $\delta_{l}$, which is a vector of "vehicle type" fixed effects for the trade-in vehicle $(l)$ used by customer $i$ to purchase vehicle $j$. A "vehicle type" in our data is the interaction of make, model, model year, trim level, doors, body type, displacement, cylinders, and transmission. (For example, one "vehicle type" in our data is a 2005 Toyota Camry LE 4-door sedan with a 6-cylinder, 3.0-liter engine and automatic transmission.) The inclusion of the trade-in vehicle type fixed effects $\left(\delta_{l}\right)$ makes this a difference-in-differences regression whose identifying variation is differences among customers who trade in a specific vehicle in the MPGs of the replacement vehicles they buy when gasoline prices are low vs. high. This allows us to perform analysis that is in the spirit of a within customer analysis, in the sense that we are estimating the effect of gasoline prices on MPG choice, conditioning on the prior purchase of a very specific vehicle. ${ }^{10}$

The results of estimating equation 1 are reported in Table 1. We estimate equation 1 separately for transactions in which buyers buy a new vehicle (reported in column 1) and transactions in which buyers buy a used vehicle (reported in column 2). In both columns, we find that higher gasoline prices are associated with consumers choosing a higher level of fuel economy (MPG) for their new vehicle relative to the fuel economy of their trade-in. The estimated coefficient implies that a $\$ 1$ increase in the gasoline price leads customers to increase the fuel economy of their new vehicle by 0.83 miles per gallon relative to their trade-in. ${ }^{11}$ For used vehicles, we find that a $\$ 1$ gasoline price increase increases the fuel economy of the newly purchased used vehicle by 0.41 miles per gallon relative to the trade-in.

We infer from these results is that vehicle buyers do respond to gasoline prices by changing the MPG of the vehicles they buy, as previous research has found, and that this effect is not an artifact of selection or composition effects during high vs. low gasoline price times, but that during high gasoline price periods, individual customers choose to buy higher MPG vehicles relative to their own past purchases than they do when gasoline prices are low.

In the next two sections, we estimate what effect this change in individual behavior has on market outcomes: the equilibrium sales and transaction prices of vehicles of different fuel economies.

of the country. Regions vary in both geographic size and population, but are designed to correspond to regional automobile markets.

${ }^{10}$ We cannot generate a true within-customer estimate because we do not observe multiple new car purchases by the same customer. We also do not know when a trade-in was purchased because a given model year is usually available for well over a year (as long as 18 months is not uncommon). Furthermore, we cannot tell if the trade-in was originally purchased as a new or a used vehicle.

${ }^{11}$ Because of the included year fixed effects, this coefficient does not measure merely changes in market tastes for high- vs. low-MPG vehicles over time. Year-to-year differences in these tastes will be absorbed by the region-specific year fixed effects $\left(\tau_{r T}\right)$. 
Table 1: New and Used Cars: Trade-in results ${ }^{\dagger}$

\begin{tabular}{|c|c|c|}
\hline & $\begin{array}{c}\text { New Cars } \\
\text { MPG }\end{array}$ & $\begin{array}{c}\text { Used Cars } \\
\text { MPG }\end{array}$ \\
\hline GasolinePrice & $\begin{array}{l}83^{* *} \\
(.04)\end{array}$ & $\begin{array}{l}.41^{* *} \\
(.023)\end{array}$ \\
\hline PctLessHighSchool & $\begin{array}{l}-.46^{*} \\
(.17)\end{array}$ & $\begin{array}{l}-.13 \\
(.17)\end{array}$ \\
\hline PctCollege & $\begin{array}{c}.75^{* *} \\
(.2)\end{array}$ & $\begin{array}{l}.58^{* *} \\
(.11)\end{array}$ \\
\hline Income & $\begin{array}{c}-6.6 \mathrm{e}-06^{* *} \\
(1.7 \mathrm{e}-06)\end{array}$ & $\begin{array}{l}-7.7 \mathrm{e}-07 \\
(9.4 \mathrm{e}-07)\end{array}$ \\
\hline MedianHHSize & $\begin{array}{l}-.12^{* *} \\
(.043)\end{array}$ & $\begin{array}{l}-.067^{*} \\
(.032)\end{array}$ \\
\hline MedianHouseValue & $\begin{array}{l}-1.8 \mathrm{e}-07 \\
(6.4 \mathrm{e}-07)\end{array}$ & $\begin{array}{c}-9.3 \mathrm{e}-07^{* *} \\
(2.6 \mathrm{e}-07)\end{array}$ \\
\hline VehiclePerHH & $\begin{array}{l}-.064 \\
(.22)\end{array}$ & $\begin{array}{l}-.18 \\
(.18)\end{array}$ \\
\hline TravelTime & $\begin{array}{l}.0063+ \\
(.0035)\end{array}$ & $\begin{array}{l}.0047^{*} \\
(.0018)\end{array}$ \\
\hline Weekend & $\begin{array}{l}.2^{* *} \\
(.026)\end{array}$ & $\begin{array}{l}.12^{* *} \\
(.01)\end{array}$ \\
\hline EndOfMonth & $\begin{array}{l}.13^{* *} \\
(.0084)\end{array}$ & $\begin{array}{l}-.0077 \\
(.007)\end{array}$ \\
\hline EndOfYear & $\begin{array}{l}.059^{*} \\
(.022)\end{array}$ & $\begin{array}{l}.085^{* *} \\
(.016)\end{array}$ \\
\hline Constant & $\begin{array}{l}17^{* *} \\
(.17)\end{array}$ & $\begin{array}{l}19^{* *} \\
(.11)\end{array}$ \\
\hline $\begin{array}{l}\text { Observations } \\
\text { R-squared }\end{array}$ & $\begin{array}{c}4156663 \\
0.060\end{array}$ & $\begin{array}{c}2923323 \\
0.018\end{array}$ \\
\hline
\end{tabular}

\section{$5 \quad$ New vehicle markets}

In order to understand the effect of gasoline price changes on auto manufacturers and dealers, we begin by estimating the effect of gasoline prices on the sales and price outcomes in the market for new vehicles. We will focus on how the effects of gasoline price changes differ for high vs. low fuel economy vehicles. In Section 7, we will investigate how these effects differentially affect individual auto manufacturers. While most of the major auto manufacturers technically have a full product line, ${ }^{12}$ there are substantial differences across manufacturers in the market segments in which they have attractive, competitive products. As a consequence, the equilibrium effects of gasoline prices on sales and vehicle prices that we estimate can have very different effects on manufacturers, depending on their product mixes.

\footnotetext{
${ }^{12}$ There are, of course, exceptions. BMW does not make a pickup truck, for example.
} 


\subsection{Empirical approach}

In order to estimate how changes in gasoline prices affect the equilibrium market outcomes (prices and sales) in new vehicle markets, we will estimate true reduced forms. In general terms, our approach will be to regress market quantities $(Q)$, measured as either market shares or unit sales, and transaction prices $(P)$ on gasoline prices and other demand and supply covariates $\left(X^{D}\right.$ and $X^{S}$, respectively).

$$
\begin{aligned}
& Q=\gamma_{0}+\gamma_{1} \text { GasolinePrice }+\gamma_{2} X^{D}+\gamma_{3} X^{S}+\nu \\
& P=\lambda_{0}+\lambda_{1} \text { GasolinePrice }+\lambda_{2} X^{D}+\lambda_{3} X^{S}+\epsilon
\end{aligned}
$$

Note that $\gamma_{2}$ and $\gamma_{3}$ in equation 2 and $\lambda_{2}$ and $\lambda_{3}$ in equation 3 will estimate neither parameters of the demand curve nor parameters of the supply curve, but instead will estimate the effect of each covariate on the equilibrium value of either $P$ or $Q$. The main coefficients of interest will be $\gamma_{1}$ and $\lambda_{1}$. These coefficients will estimate the effect of changes in gasoline prices on the equilibrium vehicle quantities and prices, respectively, conditional on the effect of the other included demand and supply covariates.

\subsection{New vehicle quantities}

In this section we investigate the effect of gasoline prices on the equilibrium sales of new vehicles of different fuel economies.

\subsubsection{Quantity specifications}

We will estimate two variants of the quantity specification given in its generic form by Equation 2 . In the first variant, described in more detail below, we will estimate the effect of gasoline prices on the market shares of new vehicles in different MPG categories. The advantage of this approach is that we can use individual transaction data, including controls for the demographic characteristics of the buyer (at the Census block group level) and for the timing of the purchase, which will help to mitigate the role of selection in our results.

In the second variant, also described in more detail below, we will estimate the effect of gasoline prices on the unit sales of new vehicles in different MPG categories. Because we have to aggregate across transactions in order to create a unit sales number, in this approach we cannot use as large a set of covariates as we can in the market share specification, but this approach will capture the effect of gasoline price changes on the overall volume of vehicles sales, an effect that may be obscured in the market share specification. 
Market shares We estimate the effect of gasoline prices on market shares by using the following linear probability model.

$$
\begin{aligned}
I_{i r t}(j \in K)= & \gamma_{0}+\gamma_{1} \text { GasolinePrice }_{a t}+\gamma_{\mathbf{2}} \text { Demog }_{i} \\
& +\gamma_{\mathbf{3}} \text { PurchaseTiming }_{i t}+\tau_{r T}+\mu_{r t}+\epsilon_{i j t} .
\end{aligned}
$$

$I_{\text {irt }}(j \in K)$ is an indicator variable that is equal to 1 if the transaction in which customer $i$ buys new vehicle $j$ in region $r$ at date $t$ is for a vehicle in MPG Bin $K$. We split vehicles into 5 bins on the basis of each vehicle's EPA Combined Fuel Economy rating. ${ }^{13}$ The bins are defined in Table 2. Table 2 also reports the average market share (across all years in our sample) of each bin. (The bins divide the sample into rough quintiles.)

Table 2: MPG Bin Definitions

\begin{tabular}{|c|c|c|c|}
\hline & \multicolumn{2}{|c|}{$\begin{array}{c}\text { Vehicles in bin } \\
\text { have MPG of }\end{array}$} & $\begin{array}{c}\text { Share in } \\
\text { sample }\end{array}$ \\
\hline \hline 1 & 0 & 16 & $18.1 \%$ \\
\hline 2 & 16 & 19 & $22.5 \%$ \\
\hline 3 & 19 & 21 & $16.7 \%$ \\
\hline 4 & 21 & 24 & $21.8 \%$ \\
\hline 5 & 24 & $\infty$ & $20.8 \%$ \\
\hline
\end{tabular}

The main coefficient of interest in Equation 4 is $\gamma_{1}$, which measures the effect of the price of gasoline in PADD $a$ in week $t$ on the probability that a transaction is for a vehicle in MPG Bin $K$, an effect we will interpret as a market share effect. We will estimate Equation 4 five times, once for each bin. The estimated coefficient $\hat{\gamma}_{1}$ from the specification in which the dependent variable is equal to one if the transaction was for a vehicle in Bin 1 estimates the effect of gasoline price on the market share of vehicles in Bin 1 . The estimated coefficient $\hat{\gamma}_{1}$ from the specification in which the dependent variable is equal to one if the transaction was for a vehicle in Bin 2 estimates the effect of gasoline price on the market share of vehicles in Bin 2, and so on.

We include as covariates the same demographic characteristics, purchase timing indicators, and region-specific year $\left(\tau_{r T}\right)$ and region-specific month-of-year $\left(\mu_{r t}\right)$ fixed effects that were used as covariates in Equation 1. These fixed effects allow for secular or seasonal differences in the market shares of vehicles in different bins and allows these difference to vary by region of the country. The inclusion of these fixed effects mean that the variation that identifies our gasoline price effects is variation within a year and region that differs from the average pattern of seasonal variation within

\footnotetext{
${ }^{13}$ Note that the correct units in which to measure the rate at which a vehicle consumes gasoline is gallons per mile, which is the inverse of miles per gallon. Thus, small differences in MPG between vehicles with low MPG can have bigger implications for the number of gallons of fuel consumed per mile of travel than much larger differences in MPG among vehicles with high MPG.
} 
that region.

We do not include explicit supply covariates in Equation 4. Supply covariates that we might control for — such as prices of raw materials, labor, and energy — are unlikely to vary to a significant degree within the region-specific year and region-specific month-of-year fixed effects that are already included in the specification.

Unit sales In order to estimate the effect of gasoline prices on unit sales, we need to aggregate from individual transactions to the number of new vehicles sold in a particular time period. The transaction data that we used to estimate the market share specification in Equation 4 are drawn from a representative sample of car dealerships, which is why they are suitable for the market share estimation. However, we do not know exactly what fraction of dealerships the sample represents in any given year, and the fraction changes year-to-year, according to our data source. As a consequence, we cannot be confident that aggregating our transaction data will give us sales figures that represent the total sales volume in the country.

As a consequence, we take a different approach. We obtain information from Ward's Automotive on national monthly new vehicle sales by model. Using the EPA's fuel economy rating for each model, we collapse the national monthly sales data by model to national monthly sales by the fuel economy bins defined in Table 2. ${ }^{14}$ Next, we calculate from our transaction data the share of transactions for each month and each fuel economy bin that occur in each PADD. We then allocate national monthly unit sales by fuel economy bins to each of the seven PADDs according to these shares. We then regress this measure - monthly PADD-level unit sales in a given MPG bin $\left(Q_{a k t}\right)$ — on monthly PADD-level gasoline prices (GasolinePrice $\left.{ }_{a t}\right)$ and other covariates, as shown below.

$$
Q_{a k t}=\gamma_{0}+\gamma_{1} \text { GasolinePrice }_{a t}+\tau_{a T}+\mu_{a t}+\epsilon_{a k t} .
$$

Because this specification does not use individual transactions, we cannot include the demographic or purchase timing covariates that we used in Equation 4. We do include PADD-specific year and PADD-specific month-of-year fixed effects in Equation 5. We estimate Equation 5 separately for each bin, to allow the year $\left(\tau_{a T}\right)$ and month-of-year $\left(\mu_{a t}\right)$ effects to vary by bin. This allows high-MPG vehicles (such as mid-size sedans) and low-MPG vehicles (such as SUVs) to have both different seasonal sales patterns and different sales trends over time. ${ }^{15}$

\footnotetext{
${ }^{14}$ Vehicle options (such a 4- vs. 6-cylinder engine) can create variation within a model in the MPG of individual vehicles. The Ward's data do not report sales broken down by this more granular, sub-model categorization, so for models that do have such intra-model variation in MPG, we use the share of of the different sub-models sold in our transaction data to impute how many units of the model's sales reported by Ward's are for each sub-model. Note that this imputation will be meaningful only for models whose sub-models have MPGs that fall into different bins.

${ }^{15}$ It also makes the unit sales specification (Equation 5) and the market share specification (Equation 4) comparable, since the linear probability model of Equation 4 has to be estimated in five separate equations, meaning that the
} 
The main coefficients of interest in Equation 5 are the $\gamma_{1}$ 's estimated for each bin. These coefficients measure the effect of a $\$ 1$ increase in gasoline prices on the monthly PADD-level unit sales of vehicles of different fuel economies.

\subsubsection{New vehicle quantity results}

We report the full results from estimating Equations 4 and 5 in new vehicle markets in Tables A-1 and A-2 respectively. We summarize the key coefficients in Tables 3 and 4.

In Table 3, we report the estimated effects of gasoline prices on market shares of new vehicles in the five fuel economy bins. The results imply that when gasoline prices rise, the market shares of low fuel economy vehicles fall and the market shares of high fuel economy vehicles rise. A $\$ 1$ increase in gasoline prices is estimated to decrease market share by 4.2 percentage points for new vehicles whose fuel economy is below $16 \mathrm{MPG}$ (Bin 1) and by 2.9 percentage points for vehicles with fuel economy of at least 16 but less than 19 MPG (Bin 2). Given the average market shares in each of these bins, these are decreases of $22.8 \%$ and $13 \%$ respectively.

At the other end of the spectrum, the results indicate that market shares of high fuel economy vehicles rise when gasoline prices rise. For these vehicles, a $\$ 1$ increase in the price of gasoline would be predicted to increase the market share of vehicles whose fuel economy is at least 24 MPG (Bin 5) by 5.9 percentage points, a $28.7 \%$ increase relative to the average market share in this bin. The same gasoline price increase would be predicted to increase the market share of vehicles with fuel economy of at least 21 MPG but less than 24 MPG (Bin 4) by 1.5 percentage points, a $6.9 \%$ increase.

Taken together, these results suggest that when gasoline prices rise, the equilibrium market shares of new vehicles shift from low-MPG vehicles to high-MPG vehicles in the way that our results on individual consumer responses reported in Section 4 suggested they would.

Because the market share results use data on individual transactions, we can include covariates that capture demographics and purchase timing. However, the market share effects may not translate directly to unit sales effects if changes in gasoline prices change the total market size. In particular, if it is the case that increased gasoline prices are associated with recessions and decreased spending on consumer durables, then the market share results will overstate the extent to which unit sales of high fuel economy vehicles increase and understate the extent to which unit sales of low fuel economy vehicles decrease. ${ }^{16}$

fixed effect estimates are allowed to vary across bins.

${ }^{16}$ Conversely, if increased gasoline prices were associated with expansions instead of recessions and therefore with increased spending on consumer durables, then the market share results would understate the extent to which unit sales of high fuel economy vehicles increase and overstate the extent to which unit sales of low fuel economy vehicles decrease. 
Table 3: Equilibrium market share response to gasoline prices

\begin{tabular}{|c|c|c|c|}
\hline \multirow[t]{2}{*}{ Variable } & \multicolumn{3}{|c|}{ Average } \\
\hline & Coefficient & Share & Effect \\
\hline $\begin{array}{l}\text { GasolinePrice*MPG Bin 1 } \\
\text { (fuel economy }<16 \mathrm{MPG} \text { ) }\end{array}$ & $\begin{array}{c}-.042^{* *} \\
(.004)\end{array}$ & $18.4 \%$ & $-22.8 \%$ \\
\hline $\begin{array}{l}\text { GasolinePrice* MPG Bin } \mathbf{2} \\
(16 \mathrm{MPG} \leq \text { fuel economy }<19 \mathrm{MPG})\end{array}$ & $(.0028)$ & $22.4 \%$ & $-13.0 \%$ \\
\hline $\begin{array}{l}\text { GasolinePrice*M MPG Bin } \mathbf{3} \\
(19 \mathrm{MPG} \leq \text { fuel economy }<21 \mathrm{MPG})\end{array}$ & $(.0016)$ & $16.8 \%$ & $-2.2 \%$ \\
\hline $\begin{array}{l}\text { GasolinePrice } \mathbf{M P G} \text { Bin } \mathbf{4} \\
(21 \mathrm{MPG} \leq \text { fuel economy }<24 \mathrm{MPG})\end{array}$ & $(.003)$ & $21.8 \%$ & $6.9 \%$ \\
\hline $\begin{array}{l}\text { GasolinePrice* } \mathbf{M} \text { PG Bin } \\
\text { (fuel economy } \geq 24 \mathrm{MPG} \text { ) }\end{array}$ & $\begin{array}{l}.059^{* *} \\
(.0029)\end{array}$ & $20.6 \%$ & $28.7 \%$ \\
\hline
\end{tabular}

* significant at $5 \%$; ${ }^{* *}$ significant at $1 \%$; significant at $10 \%$ level. Standard errors in parentheses are robust and clustered at the region level.

The unit sales estimates summarized in Table 4 suggest that this is indeed the case. In these results, a $\$ 1$ increase in gasoline prices is estimated to decrease sales in the lowest MPG bin by 10,084 vehicles per month in the average PADD, a $27.7 \%$ decrease relative to average monthly sales of 36,442 vehicles in this bin. This is a somewhat larger percentage effect than the $22.8 \%$ decrease estimated for market share. The comparison is similar for Bin 2, where an $8.5 \%$ decrease in unit sales is predicted, in comparison to a $13 \%$ decrease in market share. At the other end of the fuel economy distribution, a $\$ 1$ increase in the price of gasoline is predicted to increase sales of vehicles in Bin 5 by 4,974 vehicles per month in the average PADD, a $15.7 \%$ increase compared to average PADD-level sales of 31,602 units in this bin. This is a smaller increase than the increase in market share of $28.7 \%$ estimated for this bin in Table 3. The results in Table 4 indicate that when gasoline prices increase, the total unit sales of vehicles fall, which means that the market share effects estimated in Table 3 would be under-predictions of decreases and over-predictions of increases if they were (mis)interpreted as unit sales effects.

Table 4: Equilibrium sales response to gasoline prices

\begin{tabular}{|c|c|c|c|}
\hline \multirow[t]{2}{*}{ Variable } & \multicolumn{3}{|c|}{ Average } \\
\hline & Coefficient & Sales & Effect \\
\hline $\begin{array}{l}\text { GasolinePrice*MPG Bin 1 } \\
\text { (fuel economy }<16 \mathrm{MPG} \text { ) }\end{array}$ & $\begin{array}{c}-10,084^{* *} \\
(1,076)\end{array}$ & 36,442 & $-27.7 \%$ \\
\hline $\begin{array}{l}\text { GasolinePrice* } \mathbf{M P G} \text { Bin } 2 \\
(16 \mathrm{MPG} \leq \text { fuel economy }<19 \mathrm{MPG})\end{array}$ & $\begin{array}{c}-7,422^{* *} \\
(1,244)\end{array}$ & 40,099 & $-18.5 \%$ \\
\hline $\begin{array}{l}\text { GasolinePrice* MPG Bin 3 } \\
(19 \mathrm{MPG} \leq \text { fuel economy }<21 \mathrm{MPG})\end{array}$ & $\begin{array}{l}-4,705^{* *} \\
(1,228)\end{array}$ & 31,590 & $-14.9 \%$ \\
\hline $\begin{array}{l}\text { GasolinePrice* } \mathbf{M P G} \text { Bin } \mathbf{4} \\
(21 \mathrm{MPG} \leq \text { fuel economy }<24 \mathrm{MPG})\end{array}$ & $(1,275)$ & 39,179 & $-5.5 \%$ \\
\hline $\begin{array}{l}\text { GasolinePrice* } \mathbf{M} \mathbf{P} \text { Bin } \mathbf{5} \\
\text { (fuel economy } \geq 24 \mathrm{MPG} \text { ) }\end{array}$ & $\begin{array}{l}4,974 * * \\
(1,108)\end{array}$ & 31,602 & $15.7 \%$ \\
\hline
\end{tabular}

${ }^{*}$ significant at 5\%; ${ }^{* *}$ significant at $1 \% ;+$ significant at $10 \%$ level. Standard errors in parentheses are robust and clustered at the region level. 
The results so far suggest that when gasoline prices increase, there is a substantial shift in both the equilibrium sales and market shares of new vehicles toward higher fuel economy cars, and that this is a consequence, at least in part, of individual vehicle buyers buying cars with higher fuel economy than they otherwise would have. In order to complete the picture of what effect this has on the automotive industry - manufacturers and dealers - we need to consider the effect on equilibrium prices of new vehicles.

\section{$5.3 \quad$ New vehicle prices}

In this section we investigate the effect of gasoline prices on the equilibrium prices of new vehicles of different fuel economies.

\subsubsection{Price specification}

We estimate the effect of gasoline prices on new vehicle prices by estimating the following specification:

$$
\begin{aligned}
P_{i r j t}= & \lambda_{0}+\lambda_{\mathbf{1}}\left(\text { GasolinePrice }_{a t} \cdot \mathrm{MPG} \operatorname{Bin}_{j}\right)+\lambda_{\mathbf{2}} \text { Demog }_{i}+ \\
& \lambda_{3} \text { PurchaseTiming }_{i t}+\delta_{j}+\tau_{r T}+\mu_{r t}+\epsilon_{i j t} .
\end{aligned}
$$

$P_{\text {irjt }}$, the price that customer $i$ pays for vehicle $j$ purchased in region $r$ at time $t$, is based on the new vehicle transaction price that the dealer and customer agree on. This price includes all factory and dealer-installed options, except for those that our data provider classifies as "not contributing to the resale value of the vehicle," for example, undercoating. We want our price variable to measure the consumer's wealth outlay for the car. As a result, we make two adjustments to the new vehicle transaction price. First, we subtract any cash rebate that a manufacturer offers to pay on behalf of the consumer to the dealer. Second, we subtract from the new vehicle transaction price any profit the customer made on his or her trade-in (or add to the purchase price any loss made on the trade-in). ${ }^{17}$ We can make this adjustment because we separately observe what the dealer pays for the trade-in vehicle and the estimated wholesale value of the vehicle (as booked by the dealer).

In Equation 6 the main coefficients of interest are $\lambda_{\mathbf{1}}$. These coefficients measure the effect of a $\$ 1$ increase in gasoline prices (in PADD $a$ in week $t$ ) on the transaction prices of vehicles of different fuel economies. To allow for the possibility that gasoline prices affect high fuel economy

\footnotetext{
${ }^{17}$ For example, suppose a consumer agrees on a price of $\$ 25,000$ for a new car and her trade-in was worth $\$ 10,000$. If the dealer paid the consumer $\$ 10,000$ for the trade-in, we would code the new vehicle price as $\$ 25,000$. However, if the dealer paid the consumer only $\$ 9,000$ for her trade, we would add $\$ 1,000$ to the new vehicle price, now coding it as $\$ 26,000$. This is because the $\$ 1,000$ loss on the trade-in is an in-kind payment with the trade-in vehicle for the new vehicle and should thus be reflected in the total wealth outlay for the new car. Similarly, if the dealer paid the consumer for the trade-in in excess of the trade-in's value, we would subtract the amount from the new vehicle price.
} 
vehicles differently from low fuel economy vehicles, we interact GasolinePrice with indicators for each of our five fuel economy bins. We will thus estimate a different gasoline price coefficient for each bin.

We account for a variety of demand covariates other than gasoline prices, specifically demographics, purchase timing, "vehicle type" fixed effects, and year, season, and regional controls. $\operatorname{Demog}_{i}$ and PurchaseTiming $i t$ are the same covariate vectors that were included in Equation 1. "Vehicle type" fixed effects $\left(\delta_{j}\right)$ are the same as the "vehicle type" fixed effects for the trade-in used in Equation 1; namely, the interaction of make, model, model year, trim level, doors, body type, displacement, cylinders, and transmission. In Equation 6, these fixed effects apply to the vehicle type of the new vehicle being purchased.

We also want to allow average price levels to differ seasonally and over the years in our sample. Since we don't want to assume that prices evolve equally across the United States, we interact the geographic region (34 throughout the U.S.) in which the vehicle was sold with year $\left(\tau_{r T}\right)$ and month-of-year $\left(\mu_{r t}\right)$ fixed effects. As a result, our results will be identified based on variation within a year and region that differs from the average pattern of seasonal variation within that region. While these fixed effects do not allow directly for changes in taste over time for different types of vehicles (e.g. the increasing popularity of SUVs), the vehicle type fixed effects $\left(\delta_{j}\right)$ already capture changes in tastes implicitly since any particular vehicle type sells as a new car only for one model-year and the model-year is part of the fixed effect. This will mitigate the extent to which our estimated gasoline price effects are driven by secular changes in taste as opposed to gasoline price fluctuations.

\subsubsection{New vehicle price results}

We report on the full results from estimating Equation 6 in Table A-3. We summarize the key coefficients $\left(\lambda_{\mathbf{1}}\right)$ in Table 5 . The reported coefficients estimate by how much equilibrium prices for vehicles with different fuel economies change for a $\$ 1$ increase in gasoline prices.

In the new vehicle market we find that, all else equal, a $\$ 1$ increase in gasoline price is associated with an average price decrease of $\$ 362$ for the lowest fuel economy vehicles (those in Bin 1 , whose fuel economy is less than $16 \mathrm{MPG}$ ). For vehicles in Bin 2, a $\$ 1$ increase in the price of gasoline is associated with a $\$ 159$ decrease in price. For high fuel economy cars, the effect is the opposite. A $\$ 1$ increase in gasoline prices is, on average, associated with a $\$ 295$ vehicle price increase for the highest fuel economy vehicles (Bin 5, whose fuel economy is greater or equal to $24 \mathrm{MPG}$ ) and a $\$ 137$ price increase for vehicles in Bin 4 . These results imply that vehicles in Bin 5 increase in price by $\$ 657$ relative to those in Bin 1. 
Table 5: New cars: Equilibrium price response to gasoline prices

\begin{tabular}{|c|c|}
\hline Variable & Coefficient (SE) \\
\hline $\begin{array}{l}\text { GasolinePrice*MPG Bin } \mathbf{1}^{\dagger} \\
\text { (fuel economy }<16 \mathrm{MPG} \text { ) }\end{array}$ & $\begin{array}{c}-362^{* *} \\
(89)\end{array}$ \\
\hline $\begin{array}{l}\text { GasolinePrice* MPG Bin } 1 \text { MPG } \leq \text { fuel economy }<19 \mathrm{MPG})\end{array}$ & $\begin{array}{c}-159^{* *^{-}-} \\
(31)\end{array}$ \\
\hline $\begin{array}{l}\text { Gasoline } \\
(19 \mathrm{MPG} \leq \text { fuel economy }<21 \mathrm{MPG})\end{array}$ & $\begin{array}{l}-20 \\
(33)\end{array}$ \\
\hline $\begin{array}{l}(21 \mathrm{MPG} \leq \text { fuel economy }<24 \mathrm{MPG})\end{array}$ & $\begin{array}{c}137^{* *}- \\
(36)\end{array}$ \\
\hline $\begin{array}{l}\text { GasolinePrice* MPG Bin } \mathbf{5} \\
\text { (fuel economy } \geq 24 \mathrm{MPG} \text { ) }\end{array}$ & $\begin{array}{c}295^{* *} \\
(32)\end{array}$ \\
\hline Price difference between highest and lowest MPG Bin: & $\$ 657$ \\
\hline
\end{tabular}

Summary Combining the results of this section and the previous section, we conclude that when gasoline prices increase, the market share, unit sales, and equilibrium prices of low fuel economy vehicles fall, and the market share, unit sales, and equilibrium prices of high fuel economy vehicles rise. This is consistent with a decrease in demand for low fuel economy vehicles, and an increase in demand for high fuel economy vehicles. The results also suggest that the market for new cars has neither a vertical supply curve (which would predict that gasoline prices should affect primarily the equilibrium prices of new vehicles with little effect on sales) nor a horizontal supply curve (which would imply that gasoline prices should affect only sales and not prices). The automobile industry is made up of oligopolistic manufacturers who produce differentiated (but substitutable products) which are sold by dealerships that have varying degrees of local market power. Since both manufacturers and dealers have some degree of market power, they have a choice when faced with a change in demand: whether to respond primarily by changing prices, primarily by allowing quantities to change, or having both change. Our results indicate that manufacturers and dealers respond to the demand change by adjusting both prices and quantities, but with bigger percentage changes in quantities than in prices. ${ }^{18}$

\section{$6 \quad$ Used vehicle markets}

In the previous section we estimated the effect of gasoline prices on new vehicle markets, which are the markets on which automobile manufacturers depend. Fluctuations in the new vehicle market could also have large effects on dealers, whose profits arise in part from sales of new vehicles. Dealers also earn significant profits from buying and selling used vehicles. In this section, we estimate the effect of gasoline prices on used vehicle markets. We do so by estimating the

\footnotetext{
${ }^{18}$ The $\$ 657$ relative price change between Bin 1 and Bin 5 is $2.6 \%$ of the average new vehicle price of $\$ 25,592$.
} 
price specification (Equation 6), the market share specification (Equation 4), and the unit sales specification (Equation 5) using data on used vehicle transactions.

\subsection{Used vehicle prices}

In estimating the price specification for used cars, we want to account for the fact that used vehicles depreciate as their mileage increases, independently of vehicle age. We do so by adding a linear spline in odometer with knots at 10,000 mile increments to Equation 6 when we estimate it with used vehicle data. ${ }^{19}$ We interact the odometer spline with indicators for the vehicle's segment and the PADD in which the transaction occurs in order to allow for different depreciation patterns for different kinds of vehicles in different areas of the country. ${ }^{20}$ We also replace the year fixed effects $\left(\tau_{r T}\right)$ in Equation 6 with segment-specific year fixed effects. This is to allow for changing tastes over time for different vehicles segments. ${ }^{21}$ To reduce the number of fixed effects we have to estimate, the used car specification interacts the segment-specific year fixed effects with PADDs instead of regions, as we did for new cars. ${ }^{22}$ The full results from estimating the price specification are reported in Table A-4.

In Table 6 we summarize the gasoline price coefficients from the price specification. The estimated effect of gasoline prices on used vehicle prices is qualitatively similar to the effects on new car prices, but larger in magnitude. Specifically, the estimated effect of a $\$ 1$ increase in gasoline prices is to decrease the average price of the lowest fuel economy vehicles, those with MPG less than 16 (Bin 1), by $\$ 1,474$. For vehicles with MPG of at least 16 but less than 19 (Bin 2), a $\$ 1$ increase in the price of gasoline is estimated to decrease the average vehicle price by $\$ 356$. For high fuel economy vehicles, gasoline prices have the opposite effect. A $\$ 1$ increase in the price of gasoline is estimated to increase the price of the highest fuel economy vehicles, those with MPG of at least 24 (Bin 5), by $\$ 922$, and to increase by $\$ 745$ the price of vehicles with MPG of at least 21 but less than 24 (Bin 4). We can summarize the comparison to the new vehicle price results by noting that the estimates imply that when gasoline prices rise by $\$ 1$ the average transaction prices of the highest fuel economy used vehicles rise by $\$ 2,396$ relative to the average transaction prices of the lowest fuel economy used vehicles. This relative price effect is almost four times the $\$ 657$ relative price effect estimated for new vehicles.

In the next subsection, we report the quantity effect for used vehicle markets, and then we

\footnotetext{
${ }^{19}$ We drop from the sample vehicles with odometer readings of 150,000 miles or more; such vehicles make up $1.14 \%$ of our sample.

${ }^{20}$ There are seven vehicle segments: Compact, Midsize, Luxury, Sporty, SUV, Pickup, and Van.

${ }^{21}$ The new car price specification did not require segment-specific year fixed effects to control for changing tastes: For new cars the car type fixed effects captured taste changes since each car type only sells during one model-year.

${ }^{22}$ In unreported results we find that using PADDs instead of regions in this interaction does not materially change the estimates.
} 
Table 6: Used cars: Equilibrium price response to gasoline prices

\begin{tabular}{|c|c|}
\hline Variable & Coefficient (SE) \\
\hline $\begin{array}{l}\text { GasolinePrice*MPG Bin } \mathbf{1}^{\dagger} \\
\text { (fuel economy }<16 \mathrm{MPG} \text { ) }\end{array}$ & $\begin{array}{c}-1474^{* *} \\
(40)\end{array}$ \\
\hline $\begin{array}{l}\text { GasolinePrice* MPG Bin } \\
(16 \mathrm{MPG} \leq \text { fuel economy }<19 \mathrm{MPG})\end{array}$ & $\begin{array}{c}-356^{* *^{-}-} \\
(48)\end{array}$ \\
\hline $\begin{array}{l}\text { Gasoline } \\
(19 \mathrm{MPG} \leq \text { fuel economy }<21 \mathrm{MPG})\end{array}$ & $\begin{array}{c}313^{* *-} \\
(21)\end{array}$ \\
\hline $\begin{array}{l}(21 \mathrm{MPG} \leq \text { fuel economy }<24 \mathrm{MPG})\end{array}$ & $\begin{array}{c}745^{* *} \\
(24)\end{array}$ \\
\hline $\begin{array}{l}\text { GasolinePrice* MPG Bin } \mathbf{5} \\
\text { (fuel economy } \geq 24 \mathrm{MPG} \text { ) }\end{array}$ & $\begin{array}{l}922^{* *} \\
(24)\end{array}$ \\
\hline Price difference between highest and lowest MPG Bin: & $\$ 2396$ \\
\hline
\end{tabular}

discuss explanations for the differences in the results between the two markets.

\subsection{Used vehicle quantities}

In this subsection, we present the effect of gasoline prices on shares and sales of used vehicles. We make a careful distinction between market shares of new vehicles and transaction shares of used vehicles. This is because changes in the proportions of new vehicles of different fuel economies that are sold are changes in market shares, in the sense that these changes will show up as changes in the fleet of vehicles on the road relative to what would be observed under a counter-factual gasoline price. Changes in the "market shares" of used vehicles sold at new car dealerships will not actually change the stock of vehicles on the road. As such, it is more appropriate to think of these changes as changes in "transaction shares," a measure of the change in the sales activity occurring at new vehicle dealerships, rather than true changes in market share.

In Table 7, we report the gasoline price coefficients obtained by estimating the market/transaction share specification (Equation 4) on data from used vehicle transactions. (Full estimates are reported in Table A-5.) The estimates indicate that when gasoline prices rise by $\$ 1$, the share of used vehicle transactions at new vehicle dealerships that is for used vehicles in the lowest MPG bin (MPG of less than 16), falls by -0.96 percentage points, a $4.8 \%$ decrease relative to an average transaction share of $20.2 \%$. At the same time, the share of used vehicle transactions that is for vehicles in the top MPG bin (MPG of 24 or more) rises by $2.5 \%$. The effects are statistically significant, but only a fraction of the size of the market share effects for new cars in the same two bins $(-22.8 \%$ and $28.7 \%$ respectively).

We also estimate the effect of gasoline prices on used vehicle unit sales at new vehicle dealerships. For new vehicles, we used data from Ward's Automotive to scale our unit sales measures up to a national level. Ward's does not record a national used vehicle sales analog to its new vehicle sales 
Table 7: Used Cars: Transaction share response to gasoline prices

\begin{tabular}{|c|c|c|c|}
\hline \multirow[t]{2}{*}{ Variable } & \multicolumn{3}{|c|}{ Average } \\
\hline & Coefficient & Share & Effect \\
\hline $\begin{array}{l}\text { GasolinePrice*MPG Bin } 1 \\
\text { (fuel economy }<16 \mathrm{MPG} \text { ) }\end{array}$ & $\begin{array}{c}-.0096^{* *} \\
(.0015)\end{array}$ & $20.2 \%$ & $-4.8 \%$ \\
\hline $\begin{array}{l}\text { GasolinePrice* } \mathbf{M} \mathbf{P} G \text { Bin } \mathbf{2} \\
(16 \mathrm{MPG} \leq \text { fuel economy }<19 \mathrm{MPG})\end{array}$ & $\begin{array}{l}.0023+ \\
(.0012)\end{array}$ & $23.4 \%$ & $1.0 \%$ \\
\hline $\begin{array}{l}\text { GasolinePrice* } \mathbf{M} \mathbf{P} \mathbf{G} \text { Bin } \mathbf{3} \\
(19 \mathrm{MPG} \leq \text { fuel economy }<21 \mathrm{MPG})\end{array}$ & $(.0015)$ & $18.0 \%$ & $-0 . \overline{4} \%$ \\
\hline $\begin{array}{l}\text { GasolinePrice* } \mathbf{M} \mathbf{P} \mathbf{G} \text { Bin } \mathbf{4} \\
(21 \mathrm{MPG} \leq \text { fuel economy }<24 \mathrm{MPG})\end{array}$ & $.0041^{* *}$ & $23.5 \%$ & $1.7 \%$ \\
\hline $\begin{array}{l}\text { GasolinePrice* } \mathbf{M} \mathbf{P} \mathbf{G} \text { Bin } \\
\text { (fuel economy } \geq 24 \mathrm{MPG} \text { ) }\end{array}$ & $(.00092)$ & $\overline{15.0 \%}$ & $2.5 \%$ \\
\hline
\end{tabular}

${ }^{*}$ significant at $5 \% ;{ }^{* *}$ significant at $1 \%$; + significant at $10 \%$ level. Standard errors in parentheses are robust and clustered at the region level.

figures, so we can't use Ward's directly to scale our used vehicle transaction data up to total used vehicle sales. Instead, we collapse our used vehicle transaction data to sales by MPG bin, PADD, and month. In order to scale these numbers up to reflect sales at the full set of dealers in the country - not just those in our sample - we multiply the sales in each "MPG bin-PADD-month" by a scaling factor equal to the ratio of the national new vehicle sales recorded by Ward's to the total number of new vehicle sold in our transaction data. This approach implicitly assumes that the share of all new vehicles sold in a month that are sold by dealers in our transaction sample is the same as the share of all used vehicles sold at new vehicle dealerships in a month that are sold by dealers in our transaction sample.

We estimate the unit sales specification (Equation 5) using this measure of unit sales of used vehicles as $Q_{a k t}$. The full results of this specification are reported in Table A-6; the gasoline price coefficients are summarized in Table 8.

Table 8: Used Cars: Equilibrium sales response to gasoline prices

\begin{tabular}{|c|c|c|c|}
\hline \multirow[t]{2}{*}{ Variable } & \multicolumn{3}{|c|}{ Average } \\
\hline & Coefficient & Sales & Effect \\
\hline $\begin{array}{l}\text { GasolinePrice*MPG Bin 1 } \\
\text { (fuel economy }<16 \mathrm{MPG} \text { ) }\end{array}$ & $\begin{array}{c}-3,857^{* *} \\
(597)\end{array}$ & 26,520 & $-14.5 \%$ \\
\hline $\begin{array}{l}\text { GasolinePrice* } \mathbf{M P G} \text { Bin } \mathbf{2} \\
(16 \mathrm{MPG} \leq \text { fuel economy }<19 \mathrm{MPG})\end{array}$ & $\begin{array}{c}-2,406^{* *} \\
(627)\end{array}$ & 28,898 & $-8.3 \%$ \\
\hline $\begin{array}{l}\text { GasolinePrice* } \mathbf{M P G} \mathbf{B i n} \mathbf{3} \\
(19 \mathrm{MPG} \leq \text { fuel economy }<21 \mathrm{MPG})\end{array}$ & $(605)$ & 23,055 & $-3.4 \%$ \\
\hline $\begin{array}{l}\text { GasolinePrice* MPG Bin 4 } \\
(21 \mathrm{MPG} \leq \text { fuel economy }<24 \mathrm{MPG})\end{array}$ & $\begin{array}{c}134 \\
(743)\end{array}$ & 29,687 & $0.5 \%$ \\
\hline $\begin{array}{l}\text { GasolinePrice* } \mathbf{M P G} \text { Bin 5 } \\
\text { (fuel economy } \geq 24 \mathrm{MPG} \text { ) }\end{array}$ & $\begin{array}{c}375 \\
(598)\end{array}$ & 17,673 & $2.1 \%$ \\
\hline
\end{tabular}

* significant at 5\%; ${ }^{* *}$ significant at 1\%; + significant at $10 \%$ level. Standard errors in parentheses are robust and clustered at the region level. 
The relationship between the transaction share and unit sales results for used vehicles is similar to the relationship between the market share and unit sales results for new vehicles, in that the unit sales effects are more negative than the market share effects, suggesting that total sales of used vehicles falls when gasoline prices increase. For used vehicles, however, this effect is more concentrated in the low fuel economy bins. In particular, the used vehicle transaction shares of the lowest two fuel economy bins are estimated to fall by $4.8 \%$ in MPG Bin 1 and be close to unchanged (a statistically weak estimate of a $1 \%$ increase) in MPG Bin 2 when gasoline price increases by $\$ 1$. However, unit sales are estimated to decrease by $14.5 \%$ and $8.3 \%$ respectively in these two bins. At the other end of the fuel economy spectrum, the transaction shares of the two highest fuel economy bins are estimated to increase by $2.5 \%$ (Bin 5 ) and $1.7 \%$ (Bin 4) when gasoline prices increase by $\$ 1$, while the point estimates imply unit sales effects that are not much smaller, $2.1 \%$ and $0.5 \%$ respectively, although the point estimates are statistically indistinguishable from zero.

As a last point of comparison, we note that the predicted unit sales effects for used vehicles (measured in percentage terms in the last column of Table 8) are distinctly smaller in magnitude than the analogous effects for new vehicles, reported in the last column of Table 4.

Inventories We can see the differences between new and used markets in the effects of gasoline prices on market/transaction shares and on unit sales echoed in the effect of gasoline prices on dealership inventories of new and used vehicles of different fuel economies. In our data, we observe an inventory-related measure, called "days to turn." Days to turn counts the number of days that a specific vehicle was on a dealer's lot before it sold. Higher average days to turn for vehicles in a particular MPG bin indicates that the dealer is carrying higher inventory levels of those vehicles. In order to investigate inventory effects, we estimate the effect of gasoline prices on days to turn by MPG bin. (The specification and results are reported in Table A-7.) We find much larger changes in days to turn in response to gasoline price changes for new than for used vehicles. For new vehicles, the estimated coefficients imply that a $\$ 1$ increase in gasoline price is associated with a 10-day increase in days to turn for cars in the lowest fuel economy bin, a $15.2 \%$ increase relative to mean of 65.7 days to turn in this bin. Conversely, we find that the same gasoline price increase reduces by 10 days the time that a car in the highest fuel economy bin remains on the lot, a $20.8 \%$ decrease relative to an average of 48.1 days. In contrast, for used cars, a $\$ 1$ higher gasoline price is estimated to increase the days to turn for vehicles in Bin 1 by $7.0 \%$ (2.9 days relative to a mean of 41.7 days), and reduced days to turn in Bin 5 by $4.2 \%$ (1.7 days compared to a mean of 40.5 days). 


\subsection{Comparing new vs. used vehicle markets}

It is somewhat surprising that gasoline prices would have such different effects in new vs. used vehicle markets. While new vehicles and used vehicles are distinctly different goods, the selection of used vehicles that are sold at new car dealerships - which is what we observe in our transaction data - are the used vehicles that are most similar to new vehicles. They are typically a few years old and in very good condition (almost half of the used vehicles in our sample are three years old or less; nearly $80 \%$ are five years old or less); the median mileage at the time of sale is 35,971 . The average transaction price of used vehicles in our data is $\$ 15,317$, compared to a price of $\$ 25,592$ for new vehicles. Furthermore, used vehicles are sold at the same dealerships by the same salespeople as new vehicles. Finally, the customers who buy new vehicles and used vehicles are similar. The average new vehicle buyer in our data comes from a Census block group with average income of $\$ 58,211$ while the average used vehicle buyer comes from a Census block group with average income of $\$ 51,018 .^{23}$

We argue that the differences in the estimated effects of gasoline prices on new and used vehicle markets arise instead from differences in the supply side of each market, and specifically, differences in what lies upstream of the dealership for new and used vehicles. For new vehicles, what is upstream of the dealership are the auto manufacturers, an oligopolistic set of suppliers who produce differentiated products. This, combined with the local market power that at least some dealerships have due to franchise boundaries, means that there is market power in the pricing of new vehicles. When demand for a particular vehicle increases, manufacturers and dealers must choose how to use that increase in demand to increase profits the most: by increasing the price of the vehicle; by keeping the price of the vehicle about the same, but letting unit sales increase instead; or by a mix of increasing price and quantity. (Similarly, when demand decreases, manufacturers and dealers must choose whether to absorb the decrease by lowering prices, by allowing unit sales to fall, or by some of each.) Which choice is better for profits depends on the shape of the demand curve and the marginal cost curve, and on the nature of competition. As described in Busse (2012), an increase in demand will lead to larger increases in equilibrium prices relative to equilibrium quantities the more inelastic demand is, the steeper the marginal cost curve is, and the greater the market power of the suppliers in the market. ${ }^{24}$ The results reported in Section 5 suggest that manufacturers and dealers generally respond to gasoline price induced changes in demand by making relatively small adjustments to prices, and allowing unit sales to change instead. ${ }^{25}$ This

\footnotetext{
${ }^{23}$ See Table 16 for comparisons of other demographic characteristics between new vehicle and used vehicle buyers.

${ }^{24}$ Conversely, and in the extreme, an increase in demand will increase only equilibrium quantities, with no change in the price, if demand increases in a perfectly competitive market with constant marginal costs.

${ }^{25}$ In Section 8, we investigate whether gasoline price effects differ when gasoline prices are high or low, when they are increasing or decreasing, etc. In general, we find that the estimated effects don't vary much across these
} 
result indicates some combination of demand being somewhat elastic, marginal costs not being too steep, and automobile manufacturers not having too much market power.

For used vehicle markets, what is upstream of the dealership are wholesale automobile auctions. According to a 2010 report of the National Auto Auction Association, there are 316 auto auctions in North America. According to the same report, in most years in our sample between 9 and 10 million vehicles a year are sold at auction, and new vehicle dealerships acquire about a third of their used vehicles at auction. ${ }^{26}$ An auto auction site typically holds weekly auctions, with the averagesized facility running eight simultaneous auction lanes. The sellers at auto auctions include not only dealers who are selling trade-ins they don't want to sell at their own dealerships, but also financial institutions (such as banks or manufacturer-affiliated lessors) who need to sell off lease returns and fleet companies (such as car rental agencies) that wish to cycle cars out of service after a year or two on the road. Buyers are primarily dealerships, both franchised new vehicle dealerships and stand-alone used vehicle dealerships. New vehicle dealerships would typically attend the auction every week, often acting as both a buyer and a seller on the same day. Because of this, auctions have tremendous potential to transmit market price information quickly throughout a local market. An auction also provides a way for dealerships to convert vehicles to cash and vice versa within a short time frame at fairly low transaction cost.

A second difference between new and used markets is that in used vehicle markets, gasoline prices are relevant to the reservation price that both a buyer and a seller have for a vehicle. The cost of driving for the owner of a low-MPG vehicle is going to increase with gasoline prices by approximately the same amount as a potential buyer's cost of driving that vehicle, assuming the two drive approximately the same distance each year. If it is the case that the reservation price of the potential buyers for vehicles in a given MPG bin change by about the same amount as the reservation prices of the potential sellers of vehicles in that MPG bin, then it is not surprising that the equilibrium prices would change by that same amount. In a simple supply and demand model, if the reservation prices of buyers and sellers all fell by the same amount, the supply curve and the demand curve would both shift down by the same amount, and the new equilibrium price would be lower by the same amount as the reservation prices had fallen, leaving equilibrium quantities the same. While this is almost certainly too simple a model for the used car market, it is not implausible that the marginal buyers and sellers of particular vehicles might have similar driving habits, meaning that at the margin, reservation prices for buyers and sellers would change similarly, leading to a potentially large effect on equilibrium prices.

The fact that gasoline prices have very different effects in new and used markets is relevant

conditions.

${ }^{26}$ The biggest source of used vehicles for dealerships is trade-ins, which supply $50-60 \%$ of used vehicles. 
for understanding how manufacturers and especially dealers are affected by changes in gasoline prices, as we will describe more fully in the next section. However, these results also illustrate a more general point, which is that the effect on market outcomes of events such as a change in the price of a complementary good depends on the structure of the market itself. One area in which this is particularly relevant is environmental economics. In recent years, environmental policy has increasingly relied on price-based instruments (such as tradable permits) to accomplish environmental objectives by influencing market outcomes, rather than by using direct commandand-control mechanisms to determine those outcomes. Several recent papers have shown that the effect of such environmental instruments depends on the structure of the target markets (Mansur (2007), Busse and Keohane (2007), Fowlie (2010)). This paper suggests that the effect of a gasoline tax or carbon tax, which would operate in vehicle markets by affecting the price of gasoline, would depend on the structure of vehicle markets.

\section{$7 \quad$ Winners and losers}

Manufacturers differ considerably in the composition of their product mix. For example, Subaru's product line focuses on all-wheel-drive wagons, sedans, and crossovers. BMW's product line focuses on sports sedans. Even for the large American and Asian manufacturers, who offer a full product line of compact cars, mid-size cars, luxury cars, sports cars, SUVs, pickups, and vans, manufacturers differ in the vehicle segments in which they offer market-leading products, and therefore in which segments they are most dependent upon for revenues and profitability.

As a result, manufacturers will differ in their exposure to gasoline prices. A manufacturer (or dealer) that typically makes a large share of its sales in SUVs and pickups is likely to be hurt by gasoline price increases. A manufacturer (and its associated dealers) that sell market leading compact and mid-size cars may be helped by a gasoline price increase. In this section we investigate the implications of our estimates for different car companies, assessing who will be the biggest winners and losers when gasoline prices change.

Table 9 shows the breakdown of 11 major manufacturers' sales by fuel economy bins. ${ }^{27}$ Stark differences are apparent. During our sample period, at least $25 \%$ of the sales of Chrysler, Ford, and GM were Bin 1 vehicles (MPG less than 16). Meanwhile BMW, Honda, Hyundai, Mazda, and VW had no more than a few percentage points of sales of vehicles in this MPG range. On the other end of the spectrum, for Honda, Hyundai, Mazda, and Toyota at least 30\% of their sales were of Bin 5 vehicles (at least $24 \mathrm{MPG}$ ). But this category of vehicles represented no more than $15 \%$ of

\footnotetext{
${ }^{27}$ For manufacturers with multiple nameplates, Table 9 aggregates the sales across nameplates. For example, Honda contains sales of Honda and Acura vehicles; GM contains sales of Chevrolet, Buick, GMC, and Cadillac.
} 
the sales of BMW, Chrysler, Ford, GM, and Mercedes during our sample period.

The distributions are even more lopsided if one compares sales shares in the bottom two bins to those in the top two bins of fuel economy. More than half the vehicles sold by four manufacturers have MPG of less than 19: Chrysler (70\%), Ford (61\%), GM (52\%) and Mercedes (51\%). At the same time, for five manufacturers at least half their sales are of vehicles with MPG of more than 21: Mazda (63\%), Hyundai (65\%), Toyota (64\%), Honda (75\%), and VW (80\%).

While these differences are inter-company differences, there are some striking similarities across companies who are headquartered on the same continent. The second panel of Table 9 shows the breakdown of sales across fuel economy bins after aggregating to region-of-origin for Asian (Honda, Hyundai, Mazda, Nissan, Toyota), European (BMW, Mercedes, VW), and U.S. (Chrysler, Ford, GM) manufacturers. Asian manufacturers as a whole sell mostly cars in the top two bins, U.S. manufacturers in the bottom two bins, and European manufacturers in the middle three bins.

Table 9: New Cars: Distribution of manufacturers' sales across fuel economy bins

\begin{tabular}{|l||c|c|c|c|c|}
\hline & $\begin{array}{c}\text { MPG Bin 1 } \\
{[0,16) \text { MPG }}\end{array}$ & $\begin{array}{c}\text { MPG Bin 2 } \\
{[16-19) \text { MPG }}\end{array}$ & $\begin{array}{c}\text { MPG Bin 3 } \\
{[19-21) \text { MPG }}\end{array}$ & $\begin{array}{c}\text { MPG Bin 4 } \\
{[21-24) \text { MPG }}\end{array}$ & $\begin{array}{c}\text { MPG Bin 5 } \\
{[24-\infty) \text { MPG }}\end{array}$ \\
\hline \hline BMW & $2.4 \%$ & $21 \%$ & $47 \%$ & $15 \%$ & $15 \%$ \\
Chrysler & $32 \%$ & $38 \%$ & $15 \%$ & $8.4 \%$ & $6.4 \%$ \\
Ford & $34 \%$ & $27 \%$ & $15 \%$ & $11 \%$ & $13 \%$ \\
GM & $26 \%$ & $26 \%$ & $16 \%$ & $18 \%$ & $14 \%$ \\
Honda & $.0047 \%$ & $12 \%$ & $13 \%$ & $31 \%$ & $44 \%$ \\
Hyundai & $1.6 \%$ & $14 \%$ & $19 \%$ & $19 \%$ & $46 \%$ \\
Mazda & $.36 \%$ & $22 \%$ & $15 \%$ & $27 \%$ & $36 \%$ \\
Mercedes & $13 \%$ & $38 \%$ & $30 \%$ & $19 \%$ & $.59 \%$ \\
Nissan & $12 \%$ & $17 \%$ & $22 \%$ & $25 \%$ & $25 \%$ \\
Toyota & $7.8 \%$ & $14 \%$ & $14 \%$ & $21 \%$ & $43 \%$ \\
VW & $1.6 \%$ & $7.3 \%$ & $11 \%$ & $49 \%$ & $31 \%$ \\
\hline \hline Asia & $5.3 \%$ & $14 \%$ & $16 \%$ & $25 \%$ & $40 \%$ \\
Europe & $4.5 \%$ & $19 \%$ & $26 \%$ & $32 \%$ & $19 \%$ \\
U.S. & $30 \%$ & $29 \%$ & $16 \%$ & $13 \%$ & $12 \%$ \\
\hline
\end{tabular}

Using the information in Table 9 on the sales mix of different manufacturers' vehicles, we can construct back-of-the-envelope estimates of who wins and loses, and by how much, when gasoline prices change. In particular, our transaction data record the negotiated retail prices that customers pay dealers for individual vehicles and also the wholesale prices that dealers pay manufacturers for those same vehicles. Meanwhile, the transaction data and the Ward's data on total industry sales allows us to construct measures of market shares and unit sales, as described in previous sections. Putting these pieces of information together, we can construct measures of retail sales (retail price $\times$ quantity), manufacturer revenue (wholesale price $\times$ quantity), and dealer net revenues ([retail price - wholesale price] $\times$ quantity). (We cannot calculate manufacturer net revenues because we 
do not have a marginal cost measure for manufacturing vehicles.)

Our aim in this section will not be to re-create what happened to industry, manufacturer, and dealer revenues over time; many of these figures could simply be looked up in industry statistical sources or in manufacturer annual reports. Rather, our aim is to extrapolate, based on our estimates, how much a $\$ 1$ increase in the price of gasoline would be predicted to change, all else equal, manufacturer revenues and dealer net revenues in this industry. This could be loosely interpreted as an attempt to form a rough estimate of what portion of the changes in manufacturer and dealer revenues during the recent period of gasoline price increases was attributable to changes in gasoline prices.

We will begin by constructing a "benchmark" measure of manufacturer revenue, based on sample averages, using elements reported in Table 10. This benchmark measure begins with the average (across all years in the sample) share of each manufacturer's sales in each of the five fuel economy bins. For example, Table 10 shows that, over all years in the sample, $2.4 \%$ of the new BMW vehicles sold in the U.S. were in fuel economy Bin 1, 21\% were in Bin 2, and so on. Next, we multiply these bin-shares by the manufacturer's average (across all years in the sample) total unit sales to obtain the manufacturer's benchmark sales volume in each bin. As Table 10 indicates, over all years in the sample, there were an average of 252,576 new BMW vehicles sold per year in the U.S.; the bin-shares imply that 6,050 (or 2.4\%) of those vehicles were in Bin 1, 53,328 vehicles per year $(21 \%)$ were in Bin 2, and so on. Next, we obtain a benchmark price, which is the average retail price (across all years in the sample) of each manufacturer's vehicles in each bin. As Table 10 reports, the average price of new BMW vehicles in Bin 1, over all years in the sample, was $\$ 73,452$; the average price of new BMW vehicles in Bin 2 was $\$ 58,797$, and so on. Multiplying the benchmark retail price in each bin by the benchmark unit sales in each bin gives us the benchmark retail revenue generated by the sales of each manufacturer's vehicles in each bin. For example, according to Table 10, the benchmark annual retail sales value of new BMW vehicles in Bin 1 was $\$ 444$ million $(6,050 \times \$ 73,452)$. Summing across bins yields a benchmark total annual retail revenue generated by sales of each manufacturer's vehicles. For BMW, this is $\$ 11.275$ billion.

In the bottom panel of Table 10, we aggregate to the region-of-origin level. For example, the table indicates that on average across years in the sample, $5.3 \%$ of the new vehicles sold by Asian manufacturers (Honda, Hyundai, Mazda, and Nissan) were vehicles in Bin 1. This corresponds to a benchmark of 263,466 vehicles per year in this bin, given an average annual total sales by these manufacturers across all bins of 4,954,461 vehicles per year. Vehicles in Bin 1 made by Asian manufacturers have an average price of $\$ 33,149$. Taken together, these elements yield a benchmark annual retail sales of $\$ 8.734$ billion dollars for vehicles in Bin 1 made by Asian manufacturers.

We can construct a measure of benchmark manufacturer revenues (as opposed to retail revenues) 
by using wholesale prices in place of retail prices. We can also construct a measure of benchmark dealer net revenues by using dealer margins in place of retail prices. (Note that dealer net revenues should be interpreted as net revenues accruing to dealers in aggregate from sales of a particular manufacturer's vehicles.) Table A-12 reports the average wholesale prices and dealer margins by manufacturer and bin that are inputs to these two calculations.

Our next step is to construct a back-of-the-envelope "counter-factual" measures of retail revenues, manufacturer revenues, and dealer net revenues based on estimates of the changes in prices and quantities in each fuel economy bin implied by a $\$ 1$ increase in gasoline prices. ${ }^{28}$ In doing so, we could use the coefficients we estimated in Section 5 in order to estimate the implied changes in retail prices and sales in each bin for each manufacturer when gasoline prices rise by $\$ 1$. However, we note that Table 9 shows strong region-of-origin differences among manufacturers in the kinds of vehicles they produce, and we wish to allow for there to be corresponding differences in the effect of gasoline prices by manufacturer region-of-origin. We accommodate this by estimating Equations 5 and 6 separately by manufacturer region-of-origin (U.S., Asia, and Europe). In addition, we estimate the effect of gasoline prices on wholesale prices and on dealer margins by estimating Equation 6 first with wholesale prices, and then with with dealer margins, in place of retail prices. ${ }^{29}$

The results of these regressions are reported in Tables A-8, A-9, A-10, and A-11. Summarizing briefly, these results suggest that when gasoline prices increase, the unit sales of high fuel economy Asian and European vehicles rise, while sales of their low fuel economy vehicles fall by roughly equal proportions. For U.S. manufacturers, however, sales of low fuel economy vehicles fall, with only a very small gain in sales of high fuel economy vehicles. This reflects a widely-held opinion that U.S. manufacturers did not offer appealing small cars during our sample period.

The results also suggest that gasoline prices have somewhat different effects on retail prices, wholesale prices, and dealer margins for manufacturers of different regions-of-origin. The results in Table A-9 indicate that when gasoline prices increase, the prices of high fuel economy vehicles (Bin 5) increase by about twice as much relative to those with low fuel economy (Bin 1) for European manufacturers as they do for Asian and U.S. manufacturers. Table A-10 suggests that the wholesale prices of high fuel economy vehicles relative to low fuel economy vehicles increase with gasoline prices by the most for U.S. manufacturers, followed by European and then Asian manufacturers.

\footnotetext{
${ }^{28}$ Note that this should not be interpreted as a full-blown counter-factual simulation such as one could obtain from a structural estimate of primitive parameters and a fully specified equilibrium model.

${ }^{29}$ We would like our measure of wholesale price to capture the incremental revenue the manufacturer received when it sold the vehicle to the manufacturer. In order to accomplish this we define wholesale price as the invoice price for the vehicle minus the "dealer holdback" (a profit margin that the manufacturer tries to guarantee the dealer by leaving it out of the invoice price) minus any direct-to-dealer or direct-to-customer rebates the manufacturer pays when the car is sold. The dealer margin is equal to the retail price minus the wholesale price, which in turn is equal to the price the dealer negotiates with the customer minus the invoice price the dealer pays for the vehicle, plus the dealer holdback and any direct-to-dealer rebates.
} 
Table 10: New Cars: Benchmark shares, sales units, retail prices, and retail revenues by MPG bin ${ }^{\dagger}$

\begin{tabular}{|c|c|c|c|c|c|c|c|}
\hline & Variable & MPG Bin 1 & MPG Bin 2 & MPG Bin 3 & MPG Bin 4 & MPG Bin 5 & Total/Average \\
\hline \multirow[t]{4}{*}{ BMW } & Bin Share & $2.4 \%$ & $21 \%$ & $47 \%$ & $15 \%$ & $15 \%$ & $100 \%$ \\
\hline & Sales units & 6,050 & 53,328 & 118,460 & 37,489 & 37,249 & 252,576 \\
\hline & Retail prices & $\$ 73,452$ & $\$ 58,797$ & $\$ 43,347$ & $\$ 42,032$ & $\$ 26,437$ & $\$ 44,641$ \\
\hline & Retail revenues & $\$ 444 \mathrm{M}$ & $\$ 3,136 \mathrm{M}$ & $\$ 5,135 \mathrm{M}$ & $\$ 1,576 \mathrm{M}$ & $\$ 985 \mathrm{M}$ & $\$ 11,275 \mathrm{M}$ \\
\hline \multirow{4}{*}{ Chrysler } & Bin Share & $\overline{3} \overline{2} \overline{\%}^{-}$ & $38 \%$ & $15 \%$ & $8.4 \%$ & $6.4 \%$ & $100 \%$ \\
\hline & Sales units & 701,014 & 848,992 & 344,477 & 186,462 & 141,881 & $2,222,825$ \\
\hline & Retail prices & $\$ 26,735$ & $\$ 25,323$ & $\$ 23,323$ & $\$ 19,321$ & $\$ 15,718$ & $\$ 24,342$ \\
\hline & Retail revenues & $\$ 18,742 \mathrm{M}$ & $\$ 21,499 \mathrm{M}$ & $\$ 8,034 \mathrm{M}$ & $\$ 3,603 \mathrm{M}$ & $\$ 2,230 \mathrm{M}$ & $\$ 54,107 \mathrm{M}$ \\
\hline \multirow{4}{*}{ Ford } & Bin Share & $3 \overline{4} \%^{-}$ & $27 \%$ & $15 \%$ & $11 \%$ & $13 \%$ & $100 \%$ \\
\hline & Sales units & 1068268 & 852,668 & 484,253 & 356,481 & 408,328 & $3,169,998$ \\
\hline & Retail prices & $\$ 28,925$ & $\$ 25,346$ & $\$ 23,259$ & $\$ 21,712$ & $\$ 16,521$ & $\$ 24,688$ \\
\hline & Retail revenues & $\$ 30,899 \mathrm{M}$ & $\$ 21,612 \mathrm{M}$ & $\$ 11,263 \mathrm{M}$ & $\$ 7,740 \mathrm{M}$ & $\$ 6,746 \mathrm{M}$ & $\$ 78,260 \mathrm{M}$ \\
\hline \multirow[t]{4}{*}{$\overline{\mathrm{GM}}$} & Bin Share & $2 \overline{6} \overline{\%}$ & $26 \%$ & $16 \%$ & $1 \overline{8} \%$ & $14 \%$ & $100 \%$ \\
\hline & Sales units & 1155911 & 1122793 & 719,061 & 788,493 & 608,757 & $4,395,015$ \\
\hline & Retail prices & $\$ 32,946$ & $\$ 28,561$ & $\$ 29,113$ & $\$ 20,299$ & $\$ 16,198$ & $\$ 26,610$ \\
\hline & Retail revenues & $\$ 38,083 \mathrm{M}$ & $\$ 32,068 \mathrm{M}$ & $\$ 20,934 \mathrm{M}$ & $\$ 16,006 \mathrm{M}$ & $\$ 9,861 \mathrm{M}$ & $\$ 116,952 \mathrm{M}$ \\
\hline \multirow[t]{4}{*}{ Hondà } & Bin Share & $.0047 \%$ & $12 \%$ & $13 \%$ & $3 \overline{1} \%$ & $44 \%$ & $100 \%$ \\
\hline & Sales units & 62 & 158,256 & 164,768 & 410,448 & 575,304 & $1,308,837$ \\
\hline & Retail prices & $\$ 30,966$ & $\$ 32,912$ & $\$ 29,447$ & $\$ 23,927$ & $\$ 19,061$ & $\$ 23,570$ \\
\hline & Retail revenues & $\$ 1.9 \mathrm{M}$ & $\$ 5,208 \mathrm{M}$ & $\$ 4,852 \mathrm{M}$ & $\$ 9,821 \mathrm{M}$ & $\$ 10,966 \mathrm{M}$ & $\$ 30,849 \mathrm{M}$ \\
\hline \multirow[t]{4}{*}{ Hyundai } & Bin Share & $1 . \overline{6} \%$ & $14 \%$ & $19 \%$ & $1 \overline{9} \%$ & $46 \%$ & $100 \%$ \\
\hline & Sales units & 9,277 & 81,023 & 111,405 & 106,385 & 265,908 & 573,998 \\
\hline & Retail prices & $\$ 23,176$ & $\$ 21,223$ & $\$ 20,843$ & $\$ 17,366$ & $\$ 15,141$ & $\$ 17,648$ \\
\hline & Retail revenues & $\$ 215 \mathrm{M}$ & $\$ 1,720 \mathrm{M}$ & $\$ 2,322 \mathrm{M}$ & $\$ 1,848 \mathrm{M}$ & $\$ 4,026 \mathrm{M}$ & $\$ 10,130 \mathrm{M}$ \\
\hline \multirow[t]{4}{*}{ Mazda } & Bin Share &.$\overline{3} \overline{6} \overline{\%}^{-}$ & $22 \%$ & $15 \%$ & $2 \overline{7} \%$ & $36 \%$ & $100 \%$ \\
\hline & Sales units & 950 & 58,336 & 38,918 & 70,373 & 93,017 & 261,593 \\
\hline & Retail prices & $\$ 21,113$ & $\$ 24,963$ & $\$ 22,553$ & $\$ 19,934$ & $\$ 17,603$ & $\$ 20,621$ \\
\hline & Retail revenues & $\$ 20 \mathrm{M}$ & $\$ 1,456 \mathrm{M}$ & $\$ 878 \mathrm{M}$ & $\$ 1,403 \mathrm{M}$ & $\$ 1,637 \mathrm{M}$ & $\$ 5,394 \mathrm{M}$ \\
\hline \multirow[t]{4}{*}{ Mercedes } & Bin Share & $13 \%$ & $38 \%$ & $30 \%$ & $1 \overline{9} \%$ & $.59 \%$ & $100 \%$ \\
\hline & Sales units & 27,484 & 83,601 & 64,906 & 40,857 & 1,297 & 218,145 \\
\hline & Reta & $\$ 67,526$ & $\$ 60,833$ & $\$ 47,185$ & $\$ 39,914$ & $\$ 51,988$ & $\$ 53,645$ \\
\hline & Retail revenues & $\$ 1,856 \mathrm{M}$ & $\$ 5,086 \mathrm{M}$ & $\$ 3,063 \mathrm{M}$ & $\$ 1,631 \mathrm{M}$ & $\$ 67 \mathrm{M}$ & $\$ 11,702 \mathrm{M}$ \\
\hline \multirow[t]{4}{*}{ Nissan } & Bin Share & $1 \overline{2} \overline{\%}^{-}$ & $17 \%$ & $2 \overline{2} \%$ & $2 \overline{5} \%$ & $25 \%$ & $100 \%$ \\
\hline & Sales units & 105,367 & 142,740 & 184,379 & 211,326 & 209,791 & 853,603 \\
\hline & Reta & $\$ 30,051$ & $\$ 27,829$ & $\$ 29,889$ & $\$ 23,045$ & $\$ 18,320$ & $\$ 25,027$ \\
\hline & Retail revenues & $\$ 3,166 \mathrm{M}$ & $\$ 3,972 \mathrm{M}$ & $\$ 5,511 \mathrm{M}$ & $\$ 4,870 \mathrm{M}$ & $\$ 3,843 \mathrm{M}$ & $\$ 21,363 \mathrm{M}$ \\
\hline \multirow[t]{4}{*}{ Toyota } & Bin Share & $\overline{7} . \overline{8} \overline{\%}^{-}$ & $14 \%$ & $14 \%$ & $2 \overline{1} \%$ & $43 \%$ & $100 \%$ \\
\hline & Sales units & 153,391 & 276,794 & 275,712 & 413,964 & 836,568 & $1,956,429$ \\
\hline & Retail prices & $\$ 36,389$ & $\$ 29,258$ & $\$ 31,845$ & $\$ 28,064$ & $\$ 19,808$ & $\$ 25,888$ \\
\hline & Retail revenues & $\$ 5,582 \mathrm{M}$ & $\$ 8,099 \mathrm{M}$ & $\$ 8,780 \mathrm{M}$ & $\$ 11,618 \mathrm{M}$ & $\$ 16,571 \mathrm{M}$ & $\$ 50,649 \mathrm{M}$ \\
\hline \multirow[t]{4}{*}{$\bar{V} \bar{W}^{-}$} & Bin Share & $\overline{1} . \overline{6} \overline{\%}^{-}$ & $7.3 \%$ & $11 \%$ & $\overline{4} \overline{9} \overline{\%}$ & $31 \%$ & $100 \%$ \\
\hline & Sales units & 5,748 & 26,123 & 39,840 & 174,878 & 111,409 & 357,997 \\
\hline & Retail prices & $\$ 52,356$ & $\$ 43,228$ & $\$ 33,938$ & $\$ 24,266$ & $\$ 23,815$ & $\$ 27,036$ \\
\hline & Retail revenues & $\$ 301 \mathrm{M}$ & $\$ 1,129 \mathrm{M}$ & $\$ 1,352 \mathrm{M}$ & $\$ 4,244 \mathrm{M}$ & $\$ 2,653 \mathrm{M}$ & $\$ 9,679 \mathrm{M}$ \\
\hline \multirow[t]{4}{*}{ Asia } & Bin Share & $5.3 \%$ & $14 \%$ & $16 \%$ & $25 \%$ & $40 \%$ & $100 \%$ \\
\hline & Sales units & 263,466 & 714,861 & 776,699 & $1,229,854$ & $1,969,581$ & $4,954,461$ \\
\hline & Retail prices & $\$ 33,149$ & $\$ 28,649$ & $\$ 28,832$ & $\$ 24,274$ & $\$ 18,695$ & $\$ 23,874$ \\
\hline & Retail revenues & $\$ 8,734 \mathrm{M}$ & $\$ 20,480 \mathrm{M}$ & $\$ 22,394 \mathrm{M}$ & $\$ 29,853 \mathrm{M}$ & $\$ 36,822 \mathrm{M}$ & $\$ 118,282 \mathrm{M}$ \\
\hline \multirow[t]{4}{*}{ Europe } & Bin Share & $4 . \overline{\%} \overline{\%}^{-}$ & $19 \%$ & $26 \%$ & $\overline{3} \overline{2} \%$ & $19 \%$ & $100 \%$ \\
\hline & Sales units & 37,247 & 155,126 & 213,267 & 264,801 & 158,277 & 828,718 \\
\hline & Retail prices & $\$ 65,840$ & $\$ 56,922$ & $\$ 42,489$ & $\$ 28,818$ & $\$ 24,598$ & $\$ 38,455$ \\
\hline & Retail revenues & $\$ 2,452 \mathrm{M}$ & $\$ 8,830 \mathrm{M}$ & $\$ 9,061 \mathrm{M}$ & $\$ 7,631 \mathrm{M}$ & $\$ 3,893 \mathrm{M}$ & $\$ 31,868 \mathrm{M}$ \\
\hline \multirow[t]{4}{*}{ U.'. } & Bin Share & $30 \overline{\%}^{-}$ & $29 \%$ & $16 \%$ & $1 \overline{3} \%$ & $12 \%$ & $100 \%$ \\
\hline & Sales units & $2,929,684$ & $2,859,802$ & $1,546,850$ & $1,313,154$ & $1,138,347$ & $9,787,837$ \\
\hline & Retail prices & $\$ 29,865$ & $\$ 26,558$ & $\$ 25,905$ & $\$ 20,507$ & $\$ 16,241$ & $\$ 25,433$ \\
\hline & Retail revenues & $\$ 87,494 \mathrm{M}$ & $\$ 75,952 \mathrm{M}$ & $\$ 40,072 \mathrm{M}$ & $26,929 \mathrm{M}$ & $\$ 18,488 \mathrm{M}$ & $248,934 \mathrm{M}$ \\
\hline
\end{tabular}

${ }^{\dagger}$ All calculations based on sample averages 
Finally, according to Table A-11, when gasoline prices increase, the dealer margins for high fuel economy vehicles increase by more than $\$ 500$ relative to the dealer margins for low fuel economy vehicles for European manufacturers; by $\$ 136$ for Asian manufacturers; and that dealer margins for high fuel economy vehicles fall relative to the margins for low fuel economy vehicles for U.S. manufacturers.

In Table 11, we report the changes in retail revenues implied by our estimates in Tables A-8 and A-9 for a $\$ 1$ increase in gasoline prices. The top line of each row reports the implied change in retail revenue arising from sales of an individual manufacturer's vehicles in that fuel economy bin. For example, the first entry indicates that when gasoline prices go up by $\$ 1$, the retail revenue generated by sales of BMW vehicles in Bin 1 is implied to fall by $\$ 203$ million. (This number is the outcome of the benchmark retail price of $\$ 73,452$ for Bin 1 BMW vehicles (Table 10, column 1, row 3) falling by $\$ 802$ (Table A-9, column 2, row 1) and the average sales volume of 6,050 (Table 10, column 1, row 2) falling by $45 \%$ (Table A-8, panel 2, row 1).) A fall of $\$ 203$ million is a $46 \%$ decrease compared to a benchmark retail revenue of $\$ 444$ million (Table 10, column 1, row 4) generated by BMW sales of vehicles in this bin.

In the last column of Table 11, we add up the implied revenue changes for each bin to obtain the total retail revenue change implied for the sales of an individual manufacturer's vehicles when gasoline prices rise by $\$ 1$. The second entry for each manufacturer in this column calculates the percentage change relative to the benchmark retail revenue reported in the last column of Table 10 (row 4 of each manufacturer's entry). These implied revenue changes differ across manufacturers for two reasons. First, manufacturers differ in the distribution of their sales across fuel economy bin. Second, our estimates allow gasoline prices to have different effects by manufacturer regionof-origin. Table 11 indicates that the retail sales of U.S. manufacturers (Chrysler, Ford, and GM) decrease the most when gasoline prices increase by $\$ 1$, both in absolute levels (\$11-19 billion), and in percentage terms (16-20\%). Retail sales of Mercedes and Nissan vehicles also decrease substantially (by 9.3 and $11 \%$ respectively), while the retail revenues generated by sales of most other manufacturers' vehicles fall by less than $5 \%$. The one exception is VW; the retail revenue generated by sales of VW vehicles actually rise when gasoline prices increase by $\$ 1$, by about $\$ 1.3$ billion, or $13 \%$. (This arises because $80 \%$ of VW's benchmark sales are vehicles in the two highest fuel economy bins.)

In the lower panel of Table 11, we calculate the implied retail revenue effects of a $\$ 1$ gasoline price increase if we aggregate to manufacturer region-of-origin. The retail revenues arising from sales of U.S. manufacturers' vehicles are implied to decrease by $\$ 44.5$ billion (18\%) when gasoline prices increase by $\$ 1$, while the retail revenues from the sale of Asian manufacturers' vehicles are implied to fall by $\$ 5.9$ billion $(5 \%)$. Retail revenues from the sale of European manufacturers' 
Table 11: New Cars: Retail revenue changes implied by $\$ 1$ increase in gasoline prices ${ }^{\dagger}$

\begin{tabular}{|c|c|c|c|c|c|c|c|}
\hline & Implied & MPG Bin 1 & MPG Bin 2 & MPG Bin 3 & MPG Bin 4 & MPG Bin 5 & Total \\
\hline BMW & $\begin{array}{l}\Delta \text { Retail revenues } \\
\% \text { change }\end{array}$ & $\begin{array}{r}\$-203 \mathrm{M} \\
-46 \%\end{array}$ & $\begin{array}{r}\$ 90 \mathrm{M} \\
2.9 \%\end{array}$ & $\begin{array}{r}\$-662 \mathrm{M} \\
-13 \%\end{array}$ & $\begin{array}{r}\$ 85 \mathrm{M} \\
5.4 \%\end{array}$ & $\begin{array}{r}\$ 493 \mathrm{M} \\
50 \%\end{array}$ & $\begin{array}{r}\$-197 \mathrm{M} \\
-1.7 \%\end{array}$ \\
\hline Chrysler & $\begin{array}{l}\Delta \text { Retail revenues } \\
\% \text { change }\end{array}$ & $\begin{array}{r}\$-5,482 \mathrm{M} \\
-29 \%\end{array}$ & $\begin{array}{r}\$-5,072 \mathrm{M} \\
-24 \%\end{array}$ & $\begin{array}{r}\$-649 \mathrm{M} \\
-8.1 \%\end{array}$ & $\begin{array}{r}\$ 227 \mathrm{M}^{-} \\
6.3 \%\end{array}$ & $\begin{array}{r}\$ 66 \mathrm{M} \\
3 \%\end{array}$ & $\begin{array}{r}\$-10,910 \mathrm{M} \\
-20 \%\end{array}$ \\
\hline Ford & $\begin{array}{l}\Delta \text { Retail revenues } \\
\% \text { change }\end{array}$ & $\begin{array}{r}\$-9,019 \mathrm{M} \\
-29 \%\end{array}$ & $\begin{array}{r}\$-5,098 \mathrm{M} \\
-24 \%\end{array}$ & $\begin{array}{r}\$-909 \mathrm{M} \\
-8.1 \%\end{array}$ & $\begin{array}{r}\$ 45 \mathrm{M}^{-} \\
6.1 \%\end{array}$ & $\begin{array}{r}\$ 194 \mathrm{M} \\
2.9 \%\end{array}$ & $\begin{array}{r}\$-14,357 \mathrm{M} \\
-18 \%\end{array}$ \\
\hline$\overline{G M}$ & $\begin{array}{l}\Delta \text { Retail revenues } \\
\% \text { change }\end{array}$ & $\begin{array}{r}\$-11,079 \bar{M} \\
-29 \%\end{array}$ & $\begin{array}{r}\$-7,562 \mathrm{M} \\
-24 \%\end{array}$ & $\begin{array}{r}\$-1,717 \mathrm{M} \\
-8.2 \%\end{array}$ & $\begin{array}{r}\$ 996 \overline{\mathrm{M}} \\
6.2 \%\end{array}$ & $\begin{array}{r}\$ 288 \mathrm{M} \\
2.9 \%\end{array}$ & $\begin{array}{r}S-19,074 \mathrm{M} \\
-16 \%\end{array}$ \\
\hline Honda & $\begin{array}{l}\Delta \text { Retail revenues } \\
\% \text { change }\end{array}$ & $\begin{array}{r}\$-.44 \mathrm{M} \\
-23 \%\end{array}$ & $\begin{array}{r}\$-669 \mathrm{M} \\
-13 \%\end{array}$ & $\begin{array}{r}\$-1,105 \mathrm{M} \\
-23 \%\end{array}$ & $\begin{array}{r}\$-1,566 \mathrm{M} \\
-16 \%\end{array}$ & $\begin{array}{r}\$ 2,570 \mathrm{M} \\
23 \%\end{array}$ & $\begin{array}{r}\$-770 \mathrm{M} \\
-2.5 \%\end{array}$ \\
\hline Hyundai & $\begin{array}{l}\Delta \text { Retail revenues } \\
\% \text { change }\end{array}$ & $\begin{array}{r}-51 \mathrm{M}^{-} \\
-24 \%\end{array}$ & $\begin{array}{r}\$-226 \mathrm{M}^{-13 \%} \\
-13\end{array}$ & $\begin{array}{r}\$-530 \mathrm{M} \\
-23 \%\end{array}$ & $\begin{array}{r}\$-291 \mathrm{M} \\
-16 \%\end{array}$ & $\begin{array}{r}\$ 962 \mathrm{M} \\
24 \%\end{array}$ & $\begin{array}{r}\$-136 \mathrm{M} \\
-1.3 \%\end{array}$ \\
\hline Mazda & $\begin{array}{l}\Delta \text { Retail revenues } \\
\% \text { change }\end{array}$ & $\begin{array}{r}\$-4.8 \mathrm{M} \\
-24 \%\end{array}$ & $\begin{array}{r}-190 \mathrm{M} \\
-13 \%\end{array}$ & $\begin{array}{r}\$-200 \mathrm{M} \\
-23 \%\end{array}$ & $\begin{array}{r}\$-222 \mathrm{M} \\
-16 \%\end{array}$ & $\begin{array}{r}\$ 386 \mathrm{M} \\
24 \%\end{array}$ & $\begin{array}{r}\$-231 \mathrm{M} \\
-4.3 \%\end{array}$ \\
\hline Mercedes & $\begin{array}{l}\Delta \text { Retail revenues } \\
\% \text { change }\end{array}$ & $\begin{array}{r}\$-847 \mathrm{M} \\
-46 \%\end{array}$ & $\begin{array}{r}\$ 149 \mathrm{M} \\
2.9 \%\end{array}$ & $\begin{array}{r}\$-394 \mathrm{M} \\
-13 \%\end{array}$ & $\begin{array}{r}\$ 88 \bar{M}^{-} \\
5.4 \%\end{array}$ & $\begin{array}{r}\$ 33 \mathrm{M} \\
49 \%\end{array}$ & $\begin{array}{r}\$-972 \mathrm{M} \\
-8.3 \%\end{array}$ \\
\hline Nissan & $\begin{array}{l}\Delta \text { Retail revenues } \\
\% \text { change }\end{array}$ & $\begin{array}{r}\overline{\$}-739 \mathrm{M} \\
-23 \%\end{array}$ & $\begin{array}{r}\$-515 \mathrm{M} \\
-13 \%\end{array}$ & $\begin{array}{r}\$-1,255 \mathrm{M} \\
-23 \%\end{array}$ & $\begin{array}{r}\$-776 \mathrm{M} \\
-16 \%\end{array}$ & $\begin{array}{r}\$ 903 \mathrm{M} \\
24 \%\end{array}$ & $\begin{array}{r}\$-2,380 \mathrm{M} \\
-11 \%\end{array}$ \\
\hline Toyota & $\begin{array}{l}\Delta \text { Retail revenues } \\
\% \text { change }\end{array}$ & $\begin{array}{r}\$-1,294 \bar{M} \\
-23 \%\end{array}$ & $\begin{array}{r}\$-1,046 \mathrm{M}^{\top} \\
-13 \%\end{array}$ & $\begin{array}{r}\$-1,998 \mathrm{M} \\
-23 \%\end{array}$ & $\begin{array}{r}\$-1,862 \bar{M} \\
-16 \%\end{array}$ & $\begin{array}{r}\$ 3,873 \mathrm{M} \\
23 \%\end{array}$ & $\begin{array}{r}\$-2,327 \bar{M} \\
-4.6 \%\end{array}$ \\
\hline $\mathrm{VW}$ & $\begin{array}{l}\Delta \text { Retail revenues } \\
\% \text { change }\end{array}$ & $\begin{array}{r}\$-138 \mathrm{M} \\
-46 \%\end{array}$ & $\begin{array}{r}\$ 27 \mathrm{M} \\
2.4 \%\end{array}$ & $\begin{array}{r}\$-176 \mathrm{M} \\
-13 \%\end{array}$ & $\begin{array}{r}\$ 238 \mathrm{M} \\
5.6 \%\end{array}$ & $\begin{array}{r}\$ 1,336 \mathrm{M} \\
50 \%\end{array}$ & $\begin{array}{r}\$ 1,287 \mathrm{M} \\
13 \%\end{array}$ \\
\hline Asia & $\begin{array}{l}\Delta \text { retail revenues } \\
\% \text { change }\end{array}$ & $\begin{array}{r}\$-2,031 \mathrm{M} \\
-23 \%\end{array}$ & $\begin{array}{r}\$-2,649 \mathrm{M} \\
-13 \%\end{array}$ & $\begin{array}{r}\$-5,100 \mathrm{M} \\
-23 \%\end{array}$ & $\begin{array}{r}\$-4,762 \mathrm{M} \\
-16 \%\end{array}$ & $\begin{array}{r}\$ 8,642 \mathrm{M} \\
23 \%\end{array}$ & $\begin{array}{r}\$-5,900 \mathrm{M} \\
-5 \%\end{array}$ \\
\hline Europe & $\begin{array}{l}\Delta \text { Retail revenues } \\
\% \text { change }\end{array}$ & $\begin{array}{r}\$-1,120 \mathrm{M} \\
-46 \%\end{array}$ & $\begin{array}{r}\$ 250 \mathrm{M} \\
2.8 \%\end{array}$ & $\begin{array}{r}\$-1,170 \mathrm{M} \\
-13 \%\end{array}$ & $\begin{array}{r}\$ 422 \mathrm{M}^{-} \\
5.5 \%\end{array}$ & $\begin{array}{r}\$ 1,956 \mathrm{M} \\
50 \%\end{array}$ & $\begin{array}{r}\$ 3 \bar{M} \overline{\mathrm{M}} \\
1.1 \%\end{array}$ \\
\hline U.S. & $\begin{array}{l}\Delta \text { Retail revenues } \\
\% \text { change }\end{array}$ & $\begin{array}{r}\$-25,515 \bar{M} \\
-29 \%\end{array}$ & $\begin{array}{r}\$-17,914 \mathrm{M} \\
-24 \%\end{array}$ & $\begin{array}{r}\$-3,261 \mathrm{M} \\
-8.1 \%\end{array}$ & $\begin{array}{r}\$ 1,672 \mathrm{M}^{-} \\
6.2 \%\end{array}$ & $\begin{array}{r}\$ 538 \mathrm{M} \\
2.9 \%\end{array}$ & $\begin{array}{r}S-44,481 \mathrm{M} \\
-18 \%\end{array}$ \\
\hline
\end{tabular}

$\dagger$ All calculations based on sample averages

vehicles are implied to rise by $\$ 339$ million (1.1\%), driven mostly by VW.

In order to calculate the implied effect of gasoline price increases on manufacturer revenues and on dealer net revenues from the sale of new cars, we can repeat the analysis we carried out in Table 11, with two changes. To calculate the implied effect on manufacturer revenue, we replace benchmark retail prices with benchmark wholesale prices (Table A-12, row 2 for each manufacturer), and replace estimated effects of gasoline prices on retail prices with estimated effects of gasoline prices on wholesale prices (Table A-10). (The unit sales benchmark and unit sales effects are the same as we used to calculate the implied retail revenue effects.) To calculate the implied effect on dealer net revenue, we redo the analysis with benchmark dealer margins (Table A-12, row 3 for each manufacturer) and estimated effects of gasoline prices on dealer margins (Table A-11).

These implied effects are reported in Table 12. The first panel of Table 12 repeats the implied changes for retail revenues that were reported in the last column of Table 11; the next two panels report the analogous results for the implied changes in manufacturer revenues and dealer net revenues. 
The results show some interesting patterns across manufacturers. The first is that the changes in manufacturer revenues are closely proportional to the changes in retail revenues. In every case, the percentage change in manufacturer revenue is within 1 percentage point of the implied change in retail revenue. This is not entirely surprising, given that the unit sales of new vehicles change much more in response to changes in gasoline prices than prices do, and that changes in unit sales are part of both retail and manufacturer revenues. However, the relationship between manufacturer revenues and dealer net revenues is much less consistent across manufacturers. The starkest contrast is between the Big Three U.S. manufacturers and all other manufacturers. For each of the U.S. manufacturers, when gasoline prices increase, dealer net revenues are implied to fall by less (as a percentage) than do manufacturer revenues. Since manufacturers and dealers are equally exposed to changes in sales, this suggests that manufacturers are to some extent insulating their dealers from the effect of gasoline price increases by some means such as increasing directto-dealer rebates or dealer holdback. The results indicate that Chrysler's revenues are implied to decrease by $20 \%$ when gasoline prices increase, while the figure is $19 \%$ for Ford and $17 \%$ for GM. The net revenues from sales of new vehicles for their respective dealership networks fall by $15 \%$, $13 \%$ and $11 \%$ respectively.

For Asian and European manufacturers, however, dealer net revenues fall by more relative to their benchmark than do manufacturer revenues when gasoline prices increase. (For VW, whose revenues rise when gasoline prices rise, the net revenues of dealers rise by less in percentage terms than do VW's revenues.) For most of the manufacturers, the difference is about 4 to 5 percentage points. The biggest difference is for Mercedes. When gasoline prices rise by $\$ 1$, the revenues of Mercedes are implied to fall by $7.6 \%$ relative to benchmark revenues, but the net revenues accruing to dealers from the sales of new Mercedes vehicles is implied to fall by $27 \%$ relative to benchmark net revenues. This suggests that Asian and European manufacturers are doing much less than their U.S. counterparts to adjust pricing instruments between themselves and their dealers so as to insulate dealers from the effect of higher gasoline prices.

In order to understand the effect of gasoline prices on dealers as well as manufacturers, we need to understand the effect of gasoline prices on the used car market, and particularly the effect of gasoline prices on dealer net revenues arising from the sale of used vehicles. We can redo the analysis that underlies Table 12 using data on the unit sales, retail prices, wholesale prices, and dealer margins of used vehicles. Table A-13 presents the benchmark values of unit sales, retail prices and retail revenues for used vehicles by MPG bin. Table A-14 reports wholesale prices and dealer margins by bin. (Note that for used vehicles, wholesale price is not revenue for auto manufacturers; instead it is either the price at which the dealership acquired the vehicle at auction, or the dealer's estimate of the market value of the car made at the point that it was accepted as a trade-in.) In 
Table 12: New Cars: Revenue changes implied by a $\$ 1$ gasoline price increase

\begin{tabular}{|l||rr||rr||rr|}
\hline & $\begin{array}{r}\text { Implied } \\
\Delta \text { Retail }\end{array}$ & $\begin{array}{r}\text { Implied } \\
\text { Revenues }\end{array}$ & $\begin{array}{r}\Delta \text { Manuf. } \\
\text { Change }\end{array}$ & $\begin{array}{r}\text { Implied } \\
\Delta \text { Revenues }\end{array}$ & $\begin{array}{r}\Delta \text { Dealer } \\
\text { Change }\end{array}$ & $\%$ \\
& Net Revenues & Change \\
\hline \hline BMW & $\$-197 \mathrm{M}$ & $-1.7 \%$ & $\$-146 \mathrm{M}$ & $-1.4 \%$ & $\$-52 \mathrm{M}$ & $-9.8 \%$ \\
Chrysler & $\$-10,910 \mathrm{M}$ & $-20 \%$ & $\$-10,574 \mathrm{M}$ & $-20 \%$ & $\$-334 \mathrm{M}$ & $-15 \%$ \\
Ford & $\$-14,357 \mathrm{M}$ & $-18 \%$ & $\$-13,887 \mathrm{M}$ & $-19 \%$ & $\$-469 \mathrm{M}$ & $-13 \%$ \\
GM & $\$-19,074 \mathrm{M}$ & $-16 \%$ & $\$-18,440 \mathrm{M}$ & $-17 \%$ & $\$-631 \mathrm{M}$ & $-11 \%$ \\
Honda & $\$-770 \mathrm{M}$ & $-2.5 \%$ & $\$-665 \mathrm{M}$ & $-2.3 \%$ & $\$-106 \mathrm{M}$ & $-7.1 \%$ \\
Hyundai & $\$-136 \mathrm{M}$ & $-1.3 \%$ & $\$-116 \mathrm{M}$ & $-1.2 \%$ & $\$-20 \mathrm{M}$ & $-5.9 \%$ \\
Mazda & $\$-231 \mathrm{M}$ & $-4.3 \%$ & $\$-211 \mathrm{M}$ & $-4.1 \%$ & $\$-19 \mathrm{M}$ & $-10 \%$ \\
Mercedes & $\$-972 \mathrm{M}$ & $-8.3 \%$ & $\$-860 \mathrm{M}$ & $-7.6 \%$ & $\$-112 \mathrm{M}$ & $-27 \%$ \\
Nissan & $\$-2,380 \mathrm{M}$ & $-11 \%$ & $\$-2,217 \mathrm{M}$ & $-11 \%$ & $\$-163 \mathrm{M}$ & $-18 \%$ \\
Toyota & $\$-2,327 \mathrm{M}$ & $-4.6 \%$ & $\$-2,147 \mathrm{M}$ & $-4.4 \%$ & $\$-180 \mathrm{M}$ & $-8.1 \%$ \\
VW & $\$ 1,287 \mathrm{M}$ & $13 \%$ & $\$ 1,269 \mathrm{M}$ & $14 \%$ & $\$ 18 \mathrm{M}$ & $4.4 \%$ \\
\hline \hline Asia & $\$-5,900 \mathrm{M}$ & $-5 \%$ & $\$-5,404 \mathrm{M}$ & $-4.8 \%$ & $\$-495 \mathrm{M}$ & $-9.6 \%$ \\
Europe & $\$ 339 \mathrm{M}$ & $1.1 \%$ & $\$ 470 \mathrm{M}$ & $1.5 \%$ & $\$-131 \mathrm{M}$ & $-9.9 \%$ \\
U.S. & $\$-44,481 \mathrm{M}$ & $-18 \%$ & $\$-43,040 \mathrm{M}$ & $-18 \%$ & $\$-1,435 \mathrm{M}$ & $-12 \%$ \\
\hline
\end{tabular}

$\dagger$ All calculations based on sample averages

Table A-15 we show the implied effect by fuel economy bin of a $\$ 1$ gasoline price increase on retail revenues arising from the sale of used vehicles. Finally, in Table 13, we show the implied effect of a $\$ 1$ gasoline price increase on all three revenue measures: retail revenue, wholesale revenue, and dealer net revenue. ${ }^{30}$

The retail revenues from sales of used vehicles echo, to some extent, the patterns for new vehicle sales. For new vehicles, the changes implied by a $\$ 1$ increase in gasoline prices for retail revenues were small to moderate decreases for Asian and European manufacturers, and large decreases for U.S. manufacturers. For used vehicles, the implied effects are decreases of 6.3 to $8.5 \%$ for vehicles made by U.S. manufacturers and smaller decreases (for BMW, Mercedes, and Nissan) or increases of 1.4 to $6.1 \%$ for the other manufacturers, with Honda vehicles experiencing the biggest implied retail revenue increases. These effects are mirrored fairly closely in the wholesale revenues, indicating that auction prices (or dealers' assessments of market values) track retail prices fairly closely.

The most interesting comparison is between the implied change in dealer net revenues arising from sales of used vehicles (Panel 3 of Table 13) and the implied change in dealer net revenues arising from sales of new vehicles (Panel 3 of Table 12). This comparison shows that dealer net revenues from the sale of used vehicles made by U.S. manufacturers are implied to fall by almost as much in percentage terms (and for Ford and GM vehicles, by more in dollar terms) when gasoline prices increase as do dealer net revenues from sales of new vehicles by the same manufacturer.

\footnotetext{
${ }^{30}$ The estimates of the effect of gasoline prices on used vehicle unit sales, retail prices, wholesale prices, and dealer margin by manufacturer region-of-origin, which are inputs to the results in Table 13, are contained in Tables A-16, A-17, A-18, and A-19.
} 
The same is not true for used and new vehicles made by Asian and European manufacturers. The difference is particularly stark for vehicles made by Honda, Hyundai, Mazda, and Toyota. While the dealer net revenues from sales of new vehicles made by these manufacturers are implied to fall by 5.9 to $10 \%$ relative to benchmark dealer net revenues when gasoline prices rise by $\$ 1$, the dealer net revenues from sales of used vehicles made by these manufacturers are implied to increase by 4.7 to $8.8 \%$ when gasoline prices rise. Because used vehicles can be sold by a dealer of any nameplate (e.g. a Ford dealer could sell a used Honda), the change in dealer net revenues from the sale of used Honda vehicles does not correspond directly to the change in dealer net revenues at Honda dealerships. Still, a dealership sells a fairly high proportion of used vehicles that are the nameplate of its dealership compared to other nameplates. So these results suggest, very loosely, that some dealerships are able to compensate for reduced new vehicle net revenues with larger used vehicle net revenues when gasoline prices increase.

Table 13: Used Cars: Revenue changes implied by a $\$ 1$ gasoline price increase

\begin{tabular}{|l||rr||rr||rr|}
\hline & $\begin{array}{r}\text { Implied } \\
\Delta \text { Retail }\end{array}$ & $\begin{array}{r}\text { Implied } \\
\text { Revenues }\end{array}$ & $\begin{array}{r}\text { Imange } \\
\text { Cholesale }\end{array}$ & $\begin{array}{r}\text { Implied } \\
\text { Revenues }\end{array}$ & $\begin{array}{r}\Delta \text { Dealer } \\
\text { Change }\end{array}$ & $\%$ \\
& Net Revenues & Change \\
\hline \hline BMW & $\$-162 \mathrm{M}$ & $-3.8 \%$ & $\$-170 \mathrm{M}$ & $-4.3 \%$ & $\$ 7.5 \mathrm{M}$ & 2.3 \\
Chrysler & $\$-2,200 \mathrm{M}$ & $-8.1 \%$ & $\$-1,877 \mathrm{M}$ & $-7.9 \%$ & $\$-323 \mathrm{M}$ & -10 \\
Ford & $\$-3,795 \mathrm{M}$ & $-8.5 \%$ & $\$-3,260 \mathrm{M}$ & $-8.3 \%$ & $\$-535 \mathrm{M}$ & -10 \\
GM & $\$-3,818 \mathrm{M}$ & $-6.3 \%$ & $\$-3,123 \mathrm{M}$ & $-5.9 \%$ & $\$-695 \mathrm{M}$ & -9.9 \\
Honda & $\$ 490 \mathrm{M}$ & $6.1 \%$ & $\$ 422 \mathrm{M}$ & $5.8 \%$ & $\$ 69 \mathrm{M}$ & 8.8 \\
Hyundai & $\$ 147 \mathrm{M}$ & $5.5 \%$ & $\$ 123 \mathrm{M}$ & $5.4 \%$ & $\$ 23 \mathrm{M}$ & 6.3 \\
Mazda & $\$ 87 \mathrm{M}$ & $4.3 \%$ & $\$ 74 \mathrm{M}$ & $4.2 \%$ & $\$ 13 \mathrm{M}$ & 5.7 \\
Mercedes & $\$-220 \mathrm{M}$ & $-5.4 \%$ & $\$-222 \mathrm{M}$ & $-5.9 \%$ & $\$ 2 \mathrm{M}$ & .64 \\
Nissan & $\$-132 \mathrm{M}$ & $-1.7 \%$ & $\$-142 \mathrm{M}$ & $-2 \%$ & $\$ 9.6 \mathrm{M}$ & 1.2 \\
Toyota & $\$ 218 \mathrm{M}$ & $1.4 \%$ & $\$ 150 \mathrm{M}$ & $1.1 \%$ & $\$ 68 \mathrm{M}$ & 4.7 \\
VW & $\$ 169 \mathrm{M}$ & $5.5 \%$ & $\$ 132 \mathrm{M}$ & $4.8 \%$ & $\$ 37 \mathrm{M}$ & 12 \\
\hline \hline Asia & $\$ 852 \mathrm{M}$ & $2.4 \%$ & $\$ 665 \mathrm{M}$ & $2 \%$ & $\$ 186 \mathrm{M}$ & 5.2 \\
Europe & $\$-177 \mathrm{M}$ & $-1.6 \%$ & $\$-226 \mathrm{M}$ & $-2.2 \%$ & $\$ 49 \mathrm{M}$ & 5.3 \\
U.S. & $\$-9,836 \mathrm{M}$ & $-7.5 \%$ & $\$-8,283 \mathrm{M}$ & $-7.1 \%$ & $\$-1,553 \mathrm{M}$ & -10 \\
\hline
\end{tabular}

$\dagger$ All calculations based on sample averages

The above calculations estimate the revenue effects taking the average distribution of sales across bins - averaged over our entire sample. We push these results in two directions. First, we calculate what these imply for changes in profitability, under a variety of assumptions regarding own-price elasticities. Second, we calculate the implied changes in revenues and profits at different points in time. We stress throughout that these represent back-of-the-envelope calculations and therefore come with a number of caveats. A comprehensive estimation of the impact of changes of gasoline prices on revenues and profitability would require a structural model of three primitives of the industry: the demand for vehicles, the marginal costs of production, and costs associated with changing the product mix of vehicles offered by a manufacturer. These are beyond the scope 
of this paper, but our reduced form estimates allow us to approximate these relationships.

Abstracting away from the multi-product nature of the firms, given assumptions on the ownprice elasticities of vehicles, we can calculate what the changes in manufacturer prices and sales imply for changes in profitability. To implement this, we use assumptions on own-price elasticities, consistent with the demand estimation literature, to "identify" vehicle marginal costs. Given the new set of prices and quantities from our reduced form impacts, we can calculate the change in profits. ${ }^{31}$ As with the revenue impacts we do this by firm and also across regions-of-origin.

Figures 3, 4, and 5 illustrate that the distribution of sales across bins changed considerably over our sample. We can see evidence in the raw data of a shift towards higher fuel economy cars that started in 2006 and that for European and U.S. manufacturers seems to have accelerated after the beginning of the economic crisis. During the first half of our sample - from 1998 to 2004 - the share of sales of Asian manufacturers' vehicles that were in Bin 5 of the fuel economy distribution averaged 29\%. By 2010, Asian manufacturers increased the share of Bin 5 sales to over 57\%, while Bin 1 and 2 sales fell to levels below their 1998 levels. The sales mix of European and U.S. manufacturers changed even more drastically. During the first half of the sample the percentage of Bin 5 vehicles sold by European manufacturers average only $7.2 \%$. By 2010, this increased to $38.6 \%$. The bulk of this increase came from a reduction in the sales of Bin 4 vehicles (falling from $20.1 \%$ to $11.1 \%$ ), but both Bin 2 and 3 vehicles sales also fell.

The pattern of U.S. manufacturers is slightly different. The share of vehicles in Bins 5 and 4 increased dramatically, with the share in Bin 5 increasing from an average of $8.0 \%$ during the first half of the sample to $19.5 \%$ in 2010. Unlike Asian and European sales, this increase came predominantly from a reduction in Bin 1 sales; the average share of Bin 1 sales was $36.1 \%$ during the first half of the sample, while it was only $10.7 \%$ in 2010.

The observed changes in the distribution of sales is a result of changes in both consumer preferences and shifts in the products offered by manufacturers as a response to these changes in preferences. Figures A-1, A-2, and A-3, in the appendix, provide similar graphs based on the cars offered by manufacturer, rather than the sales-weighted graphs above. These figures suggest that manufacturers did indeed change the mix of vehicles that they offered over this time period. ${ }^{32}$ If we believe that the changes in distributions represent, at least in part, conscious decisions by manufacturer to change the mix of vehicles they offer, then comparing the different affects of

\footnotetext{
${ }^{31}$ We assume that marginal costs do not change over time. This may not be true in reality for two countervailing reasons. On the one hand, technological progress is driving down the cost of offering more fuel-efficient vehicles. On the other hand, firms may have increased the amount of costly technology embedded in vehicles over this time period.

${ }^{32}$ Given that we have fixed the cut-offs for each bin, technological progress will tend to push manufacturers to higher bins independent of changes in gasoline prices, but the observed rate is much faster than that would be predicted by the results in Knittel (2011).
} 
Figure 3: Annual share of new vehicles sold by bin, Asian manufacturers

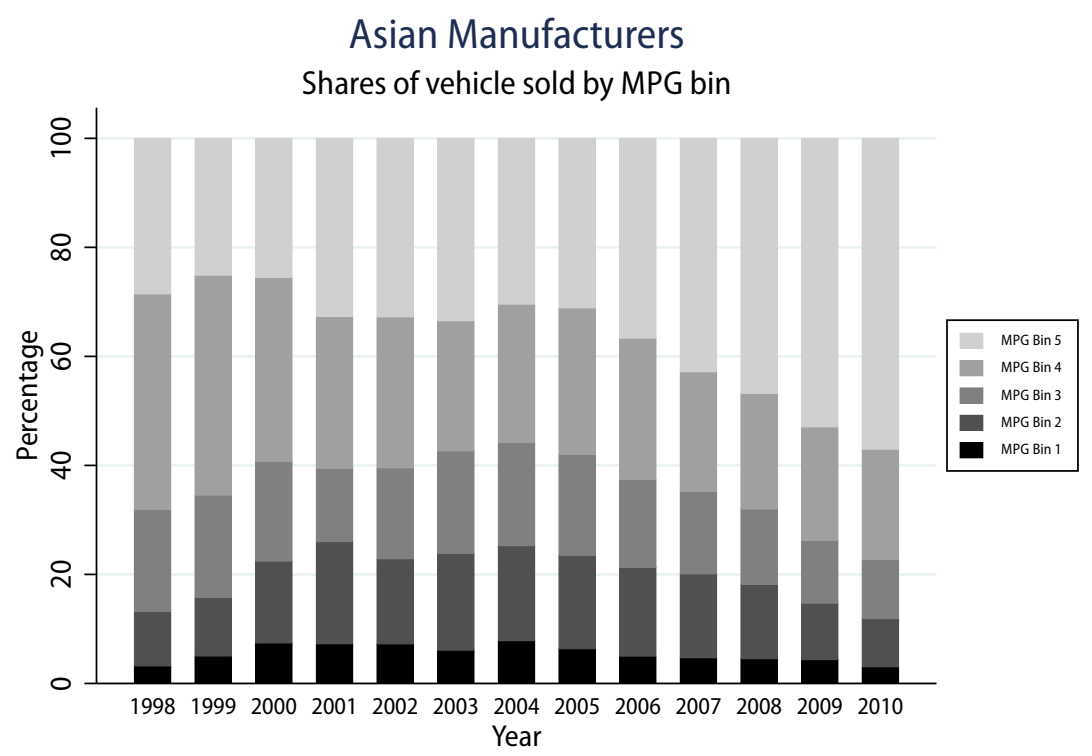

Figure 4: Annual share of new vehicles sold by bin, European manufacturers

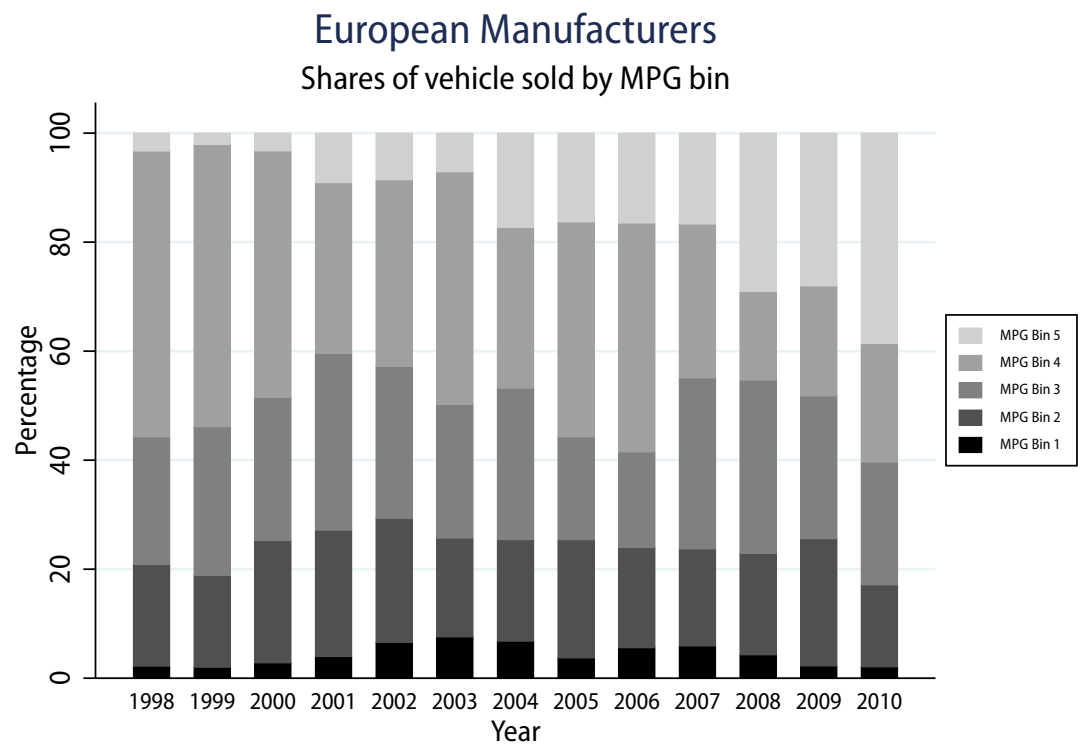

gasoline prices at points in time gives some indication of the differences in the degree to which manufacturers insulated themselves from additional increases in gasoline prices. Alternatively, if we observe one manufacturer shifting its distribution considerably more than another, this may 
Figure 5: Annual share of new vehicles sold by bin, U.S. manufacturers

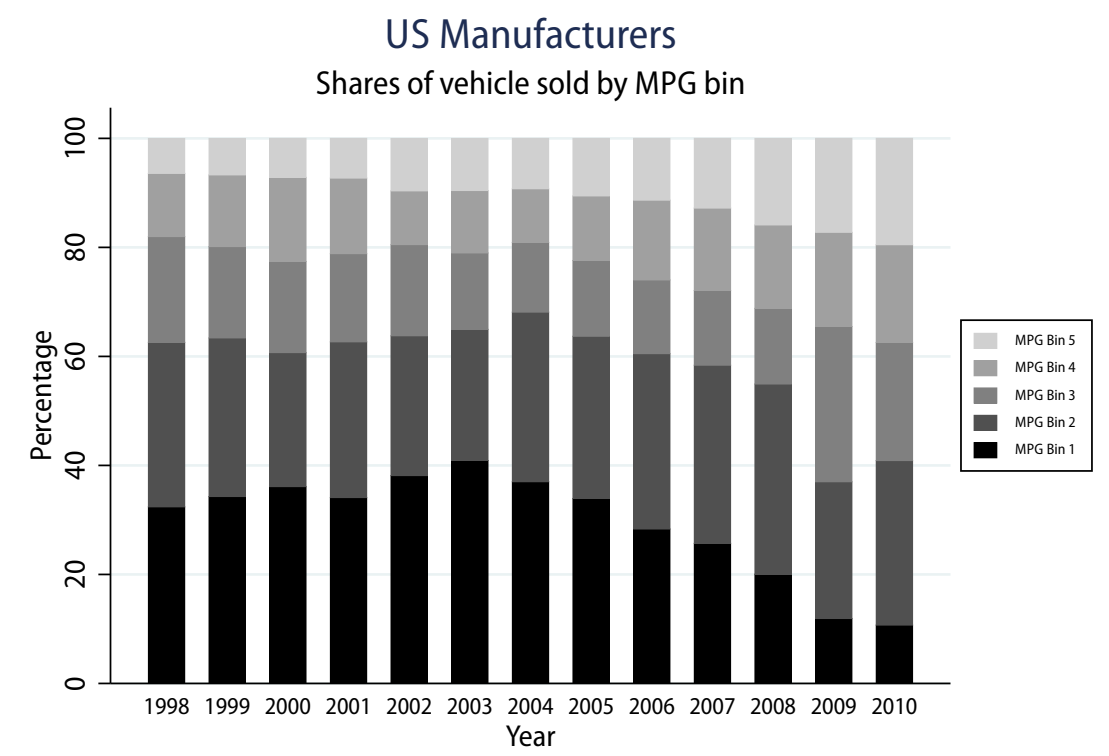

indicate that manufacturers vary in their ability to increase offerings of higher fuel economy vehicles.

To understand the implications of these distributional shifts, we calculate the change in revenues for the observed distribution of bin sales for 2002 - the year just prior to gasoline prices beginning their rise - and 2010 - the last full year of data in our sample - by manufacturer and origin. We also calculate the implied change in profits under a variety of assumptions on the own-price elasticity. Given that the manufacturers are making product offering decisions, we focus on the effects on manufacturers. To calculate the change in profits, we calculate the implied markup prior to a $\$ 1$ increase in gasoline prices:

$$
\frac{P-m c}{P}=\frac{1}{\eta}
$$

where $\eta$ is the assumed own-price elasticity. We then reduce this markup by our set estimated price impact and combine this with our estimates on the sales effect to calculate the implied change in profits. For example, if we estimate that the effect of a $\$ 1$ change in gasoline prices on the price of a given vehicle is to reduce its price by $X$, the new markup is estimated to be the mark up given by equation (7) minus $X$. We report the estimated profit impacts for own-price elasticities of -4 , -5 , and -6 . These are consistent with those estimates, for example, in Berry, Levinsohn, and Pakes (1995).

Table 14 reports manufacturer-specific changes in revenues using the distribution of sales in 2002, while Table 15 reports manufacturer-specific changes in revenues using the distribution of 
sales in 2010.

Table 14: New Cars: Revenue and profit changes implied by a $\$ 1$ gasoline price increase in 2002

\begin{tabular}{|c|c|c|c|c|c|c|c|c|}
\hline & $\begin{array}{r}\text { Implied } \\
\Delta \text { Manuf. } \\
\text { Revenues }\end{array}$ & $\begin{array}{r}\% \\
\text { Change }\end{array}$ & $\begin{array}{r}\text { Implied } \\
\Delta \text { Manuf. } \\
\text { Profits }\end{array}$ & $\begin{array}{r}\% \\
\text { Change }\end{array}$ & $\begin{array}{r}\text { Implied } \\
\Delta \text { Manuf. } \\
\text { Profits }\end{array}$ & $\begin{array}{r}\% \\
\text { Change }\end{array}$ & $\begin{array}{r}\text { Implied } \\
\Delta \text { Manuf. } \\
\text { Profits }\end{array}$ & $\begin{array}{r}\% \\
\text { Change }\end{array}$ \\
\hline & & & \multicolumn{2}{|c|}{ Elasticity of 4} & \multicolumn{2}{|c|}{ Elasticity of 5} & \multicolumn{2}{|c|}{ Elasticity of 6} \\
\hline BMW & $\$-995 \mathrm{M}$ & $-8.9 \%$ & $\$-207 \mathrm{M}$ & $-7.9 \%$ & $\$-163 \mathrm{M}$ & $-7.7 \%$ & $\$-133 \mathrm{M}$ & $-7.6 \%$ \\
\hline Chrysler & $\$-11,178 \mathrm{M}$ & $-22 \%$ & $\$-2,877 \mathrm{M}$ & $-23 \%$ & $\$-2,348 \mathrm{M}$ & $-24 \%$ & $\$-1,995 \mathrm{M}$ & $-24 \%$ \\
\hline Ford & $\$-16,752 \mathrm{M}$ & $-21 \%$ & $\$-4,219 \mathrm{M}$ & $-22 \%$ & $\$-3,424 \mathrm{M}$ & $-23 \%$ & $\$-2,895 \mathrm{M}$ & $-23 \%$ \\
\hline GM & $\$-22,574 \mathrm{M}$ & $-18 \%$ & $\$-5,616 \mathrm{M}$ & $-19 \%$ & $\$-4,545 \mathrm{M}$ & $-19 \%$ & $\$-3,831 \mathrm{M}$ & $-20 \%$ \\
\hline Honda & $\$-1,743 \mathrm{M}$ & $-6.1 \%$ & $\$-200 \mathrm{M}$ & $-3 \%$ & $\$-115 \mathrm{M}$ & $-2.2 \%$ & $\$-59 \mathrm{M}$ & $-1.3 \%$ \\
\hline Hyundai & $\$-452 \mathrm{M}$ & $-4.7 \%$ & $\$-34 \mathrm{M}$ & $-1.5 \%$ & $\$-9.2 \mathrm{M}$ & $-.51 \%$ & $\$ 7.2 \mathrm{M}$ & $.48 \%$ \\
\hline Mazda & $\$-269 \mathrm{M}$ & $-5.3 \%$ & $\$-43 \mathrm{M}$ & $-3.5 \%$ & $\$-29 \mathrm{M}$ & $-3 \%$ & $\$-20 \mathrm{M}$ & $-2.4 \%$ \\
\hline Mercedes & $\$-973 \mathrm{M}$ & $-9 \%$ & $\$-224 \mathrm{M}$ & $-8.7 \%$ & $\$-182 \mathrm{M}$ & $-8.8 \%$ & $\$-155 \mathrm{M}$ & $-9 \%$ \\
\hline Nissan & $\$-2,906 \mathrm{M}$ & $-17 \%$ & $\$-624 \mathrm{M}$ & $-15 \%$ & $\$-486 \mathrm{M}$ & $-15 \%$ & $\$-394 \mathrm{M}$ & $-15 \%$ \\
\hline Toyota & $\$-2,166 \mathrm{M}$ & $-5.1 \%$ & $\$-374 \mathrm{M}$ & $-3.7 \%$ & $\$-265 \mathrm{M}$ & $-3.3 \%$ & $\$-193 \mathrm{M}$ & $-2.8 \%$ \\
\hline VW & $\$ 752 \mathrm{M}$ & $7.1 \%$ & $\$ 261 \mathrm{M}$ & $10 \%$ & $\$ 227 \mathrm{M}$ & $11 \%$ & $\$ 205 \mathrm{M}$ & $12 \%$ \\
\hline Asia & $\$-7,822 \mathrm{M}$ & $-7.6 \%$ & $\$-1,320 \mathrm{M}$ & $-5.4 \%$ & $\$-937 \mathrm{M}$ & $-4.8 \%$ & $\$-681 \mathrm{M}$ & $-4.2 \%$ \\
\hline Europe & $\$-1,113 \mathrm{M}$ & $-3.4 \%$ & $\$-145 \mathrm{M}$ & $-1.9 \%$ & $\$-98 \mathrm{M}$ & $-1.6 \%$ & $\$-66 \mathrm{M}$ & $-1.3 \%$ \\
\hline U.S. & $\$-50,524 \mathrm{M}$ & $-20 \%$ & $\$-12,719 \mathrm{M}$ & $-21 \%$ & $\$-10,323 \mathrm{M}$ & $-21 \%$ & $\$-8,726 \mathrm{M}$ & $-22 \%$ \\
\hline
\end{tabular}

${ }^{\dagger}$ All calculations based on sales mix in 2002

Table 15: New Cars: Revenue and profit changes implied by a $\$ 1$ gasoline price increase in 2010

\begin{tabular}{|c|c|c|c|c|c|c|c|c|}
\hline & $\begin{array}{r}\text { Implied } \\
\Delta \text { Manuf. } \\
\text { Revenues }\end{array}$ & $\begin{array}{r}\% \\
\text { Change }\end{array}$ & $\begin{array}{r}\text { Implied } \\
\Delta \text { Manuf. } \\
\text { Profits }\end{array}$ & $\begin{array}{r}\% \\
\text { Change }\end{array}$ & $\begin{array}{r}\text { Implied } \\
\Delta \text { Manuf. } \\
\text { Profits }\end{array}$ & $\begin{array}{r}\% \\
\text { Change }\end{array}$ & $\begin{array}{r}\text { Implied } \\
\Delta \text { Manuf. } \\
\text { Profits }\end{array}$ & $\begin{array}{r}\% \\
\text { Change }\end{array}$ \\
\hline & & & \multicolumn{2}{|c|}{ Elasticity of 4} & \multicolumn{2}{|c|}{ Elasticity of 5} & \multicolumn{2}{|c|}{ Elasticity of 6} \\
\hline BMW & $\$ 337 \mathrm{M}$ & $2.7 \%$ & $\$ 122 \mathrm{M}$ & $4 \%$ & $\$ 107 \mathrm{M}$ & $4.3 \%$ & $\$ 97 \mathrm{M}$ & $4.7 \%$ \\
\hline Chrysler & $\$-4,656 \mathrm{M}$ & $-17 \%$ & $\$-1,149 \mathrm{M}$ & $-17 \%$ & \$ -919 M & $-17 \%$ & $\$-765 \mathrm{M}$ & $-17 \%$ \\
\hline Ford & $\$-6,348 \mathrm{M}$ & $-12 \%$ & $\$-1,508 \mathrm{M}$ & $-11 \%$ & $\$-1,192 \mathrm{M}$ & $-11 \%$ & $\$-982 \mathrm{M}$ & $-11 \%$ \\
\hline GM & $\$-7,527 \mathrm{M}$ & $-11 \%$ & $\$-1,737 \mathrm{M}$ & $-11 \%$ & $\$-1,360 \mathrm{M}$ & $-10 \%$ & $\$-1,108 \mathrm{M}$ & $-10 \%$ \\
\hline Honda & $\$ 592 \mathrm{M}$ & $1.9 \%$ & $\$ 309 \mathrm{M}$ & $4 \%$ & $\$ 289 \mathrm{M}$ & $4.7 \%$ & $\$ 276 \mathrm{M}$ & $5.4 \%$ \\
\hline Hyundai & $\$ 1,896 \mathrm{M}$ & $10 \%$ & $\$ 597 \mathrm{M}$ & $13 \%$ & $\$ 516 \mathrm{M}$ & $14 \%$ & $\$ 462 \mathrm{M}$ & $15 \%$ \\
\hline Mazda & $\$ 130 \mathrm{M}$ & $2.6 \%$ & $\$ 61 \mathrm{M}$ & $4.9 \%$ & $\$ 57 \mathrm{M}$ & $5.7 \%$ & $\$ 54 \mathrm{M}$ & $6.6 \%$ \\
\hline Mercedes & $\$-757 \mathrm{M}$ & $-6.1 \%$ & $\$-162 \mathrm{M}$ & $-5.3 \%$ & $\$-129 \mathrm{M}$ & $-5.2 \%$ & $\$-107 \mathrm{M}$ & $-5.2 \%$ \\
\hline Nissan & $\$-360 \mathrm{M}$ & $-1.6 \%$ & $\$ 24 \mathrm{M}$ & $.43 \%$ & $\$ 48 \mathrm{M}$ & $1.1 \%$ & $\$ 64 \mathrm{M}$ & $1.7 \%$ \\
\hline Toyota & $\$-566 \mathrm{M}$ & $-1.2 \%$ & $\$ 104 \mathrm{M}$ & $.88 \%$ & $\$ 142 \mathrm{M}$ & $1.5 \%$ & $\$ 167 \mathrm{M}$ & $2.1 \%$ \\
\hline VW & $\$ 3,024 \mathrm{M}$ & $28 \%$ & $\$ 842 \mathrm{M}$ & $31 \%$ & $\$ 702 \mathrm{M}$ & $33 \%$ & $\$ 609 \mathrm{M}$ & $34 \%$ \\
\hline Asia & $\$ 1,281 \mathrm{M}$ & $1 \%$ & $\$ \$ 992 \mathrm{M}$ & $3.2 \%$ & $\$ 968 \mathrm{M}$ & $3.9 \%$ & \$952 M & $4.6 \%$ \\
\hline Europe & $\$ 3,154 \mathrm{M}$ & $9 \%$ & $\$ 946 \mathrm{M}$ & $11 \%$ & $\$ 799 \mathrm{M}$ & $12 \%$ & $\$ 701 \mathrm{M}$ & $12 \%$ \\
\hline U.S. & $\$-18,467 \mathrm{M}$ & $-12 \%$ & $\$-4,382 \mathrm{M}$ & $-12 \%$ & $\$-3,463 \mathrm{M}$ & $-12 \%$ & $\$-2,850 \mathrm{M}$ & $-12 \%$ \\
\hline
\end{tabular}

${ }^{\dagger}$ All calculations based on sales mix in 2011

Across all manufacturers, the estimated impacts on revenues and profits are larger in 2002 compared to 2010. However, the degree to which this is true varies considerably. Focusing first on origin, we see that using the distribution of sales in 2002, we estimate that Asian manufacturers' revenues fell $7.6 \%$ for every $\$ 1$ increase in gasoline prices. In contrast, they gain $1 \%$ in revenues using the 2010 distribution of sales. The implied change in profits under the three different assumptions on the own-price elasticity mirrors the changes in revenues, with the profits increases 
being larger in 2010, compared to revenue increases. Comparing Asian manufacturers suggests that Hyundai saw the largest shift in their sales mix over this time period. ${ }^{33}$ Honda and Mazda had similar shifts. In 2002, the two manufacturers are estimated to have lost roughly $5 \%$ in revenues and had an even smaller loss in profits. By the end of our sample, both Honda and Mazda benefit from increases in gasoline prices, with profits increasing by between 4 and $6.6 \%$.

Nissan stands out among the Asian manufacturers. The sales mix for Nissan is similar to that of the U.S. manufacturers in 2002; a $\$ 1$ increase in gasoline prices reduced Nissan revenues by $17 \%$ and profits by $15 \%$ across all three assumptions on the own-price elasticity. Nissan's sale mix shifted drastically by 2010, and in 2010 a $\$ 1$ increase in gasoline prices is predicted to lead to slight decreases in revenues and increases in profits. Toyota did not shift its sales mix as drastically as the other Asian manufacturers. Using the 2010 sales mix, Toyota is estimated to continue to be harmed on the revenue side from increases in gasoline prices with profits effectively unchanged.

This shift from losses in 2002 to gains in 2010 is even more stark for European manufacturers. The large shift in the sales distribution from 2002 to 2010 , implies that the effect of a $\$ 1$ change in gasoline prices goes from reducing revenues of European manufacturers by over $3 \%$ and profits by roughly $1.5 \%$ in 2002 to increasing revenues by $9 \%$ and profits by over $10 \%$ in 2010 . These gains come predominantly from Volkswagen and BMW.

In terms of absolute impacts, the change between 2002 and 2010 for U.S. manufacturers swamps that of Asian and European manufacturers. In 2002, we estimate that a $\$ 1$ increase gasoline prices reduced U.S. revenues by over $\$ 50$ billion; the drop in profits ranges from nearly $\$ 9$ billion to nearly $\$ 13$ billion. By 2010, the revenue effects fell to $\$ 18.5$ billion, while the impact on profits ranges from $\$ 2.8$ to $\$ 4.4$ billion.

There are also large differences in how the U.S. manufacturers responded to the increase in gasoline prices over this time. While all three manufacturers had similar sales mixes in 2002, leading to reductions in revenues and profits of roughly 18-22\%, Ford and GM changed their sales mix considerable over this time period. In contrast, Chrysler changed very little. Using the 2010 mix, the effect on revenues and profits fall by 50\% compared to 2002 for Ford and GM. The impact of increases in gasoline prices on Chrysler remained largely unchanged.

To summarize, we find large differences across manufacturers in how their sales mixes changed during our sample. We again stress that the shifts in the distribution of sales is a mixture of both a supply and demand response. However, regardless of the cause for the shift, these calculations illustrate how the estimated impact changes over our sample. If the observed shifts are due more to demand response, then these calculations suggest which manufacturers are poised to gain from

\footnotetext{
${ }^{33}$ This consistent with Hyundai's recent ad campaign touting the fact that they are now the most fuel efficient auto company in the U.S.
} 
these shifts in demand. If they instead are due more to a supply response, then these calculations suggest which manufacturers are more capable of changing their product mix in response to a run up in gasoline prices. ${ }^{34}$ We would argue that both of these causes - and likely a mixture of the two-help us better understand the automobile industry.

\section{Heterogeneity in gasoline price response}

The specifications reported so far in the paper estimate a single coefficient for the effect of GasolinePrice on prices, market shares, or sales for each MPG bin. The implicit assumption is that the effect of gasoline prices is the same whether gasoline prices are high or low and whether gasoline prices have been rising or falling recently. One might wonder whether this is true. For example, suppose drivers experience an adjustment cost to changing vehicle types. (For example, switching away from a pickup means that a driver can't carry material for home improvement projects or pull a boat; switching away from a large SUV means a parent can't drive a carpool of kids.) If this is the case, then drivers might not respond to increases in gasoline prices until the price crosses a threshold at which it becomes worthwhile to make the necessary lifestyle switch to drive a smaller, higher fuel economy car. ${ }^{35}$

Effect sizes might differ depending on whether gasoline prices have been recently rising or falling if the direction of the recent trend affects customers' expectations of future gasoline prices, and therefore of what car they wish to own in the future. Anderson, Kellogg, and Sallee (2011) present evidence that, on average, customers expect the real price of gasoline in the future to be the current price of gasoline, which suggests that most consumers either believe that real gasoline prices are a random walk, or that they are not forming sophisticated gasoline price expectations. ${ }^{36}$ Our results below are one way to examine whether that is true.

\subsection{Heterogeneity by gasoline price levels}

In order to investigate whether customers respond differently to changes in gasoline prices when gasoline prices are high vs. low, we re-estimate the effects of gasoline prices on the prices and

\footnotetext{
${ }^{34}$ For example, comparing the U.S. firms, in $201035 \%$ and $30 \%$ of Ford and GM's offered cars, respectively, were in either Bins 1 or 2 . Only $21 \%$ of Chrysler's offerings were in Bins 1 or 2 . At the other end of the spectrum, $26.8 \%$ of Chrysler's cars were in Bin 1 in 2010, compared to $15 \%$ for Ford and $15.3 \%$ for GM.

${ }^{35}$ The automotive industry participants believe such effects exist. In an article in Automotive News on May 22 , 2008 entitled "Ford: $\$ 3.50$ gasoline was tipping point for sales shift" states: "The segment shifts [away from SUVs and pickups] 'really started to move' when gasoline prices hit $\$ 3.50$ a gallon, [Ford CEO Alan] Mulally said. 'It seemed to us that we reached a tipping point where customers began shifting away from these vehicles at an accelerated rate,'...."

${ }^{36}$ Busse, Knittel, and Zettelmeyer (forthcoming) discuss the implications of using current gasoline prices, rather than an expectations measure such as future prices, in regressions such as those estimated in this paper.
} 
market shares of new and used vehicles (Tables 3, 5, 6, and 7) using GasolinePrice interacted with indicators for whether GasolinePrice is below $\$ 2$, between $\$ 2$ and $\$ 3$, or above $\$ 3$. The purpose is to see whether there is an inflection point of gasoline prices at which the effects suddenly kick in, or at which they grow much larger.

Table A-20 reports the estimated effect of gasoline prices on the relative prices of cars of different fuel economies, both new and used, separately by the three price regions. For new vehicles, a $\$ 1$ increase in the price of gasoline has approximately the same effect on the relative price of a vehicle in Bin 5 relative to a vehicle in Bin 1 when GasolinePrice is between $\$ 2$ and $\$ 3$, and when it is above $\$ 3$. The effect is a third smaller when gasoline prices are below $\$ 2$. For used cars, the effect of GasolinePrice is also similar whether GasolinePrice is between $\$ 2$ and $\$ 3$ or above $\$ 3$, and about $17 \%$ smaller when price is less than $\$ 2$.

The estimated effects of gasoline prices on market share are reported separately by ranges of gasoline price in Table A-21. The effects for both new and used cars are quite similar in any fuel economy bin across the gasoline price ranges. The effects on market share are larger in magnitude at higher gasoline prices for most of the bins in which the estimated effects are statistically significant (new Bins 2 and 5, used Bins 1, 4, and 5) but this is not true for all such bins (new Bins 1 and 4). Generally, the estimated effects sizes differ only by several tenths of a percentage point.

Overall, we conclude that there is some evidence of larger effects of gasoline prices on vehicle prices and market shares when the price of gasoline is higher, but the appropriate characterization is that the effects are somewhat smaller at low prices (below $\$ 2$ ), not that the effects suddenly kick in strongly at high prices (above $\$ 3$ ).

\subsection{Heterogeneity by gasoline price trends}

In order to investigate whether the effect of gasoline prices on vehicle prices and market shares differs by whether gasoline prices have been trending up or down, we first need to identify periods of upward- vs. downward-trending gasoline prices. As Figure 1 shows, gasoline prices do have periods of generally upward or downward trends, but within these trends, movements are often non-monotonic. We defined periods of upward vs. downward trend by first fitting a cubic spline of weekly gasoline prices with knots at 4 month intervals, as shown in Figure 6 . We then split our sample period into spells in which the fitted spline is monotonically increasing or decreasing. A monotonic spell in which the spline rises by at least 10 cents is defined as a period of upward trending prices, denoted with dark grey shading in Figure 6. A monotonic spell in which the spline falls by at least 10 cents is defined as a period of downward trending prices, the light grey regions in Figure 6. A monotonic spell in which the price changes by less than 10 cents is defined as a period in which prices "hold," and is indicated by the white regions in Figure 6. 
Figure 6: Gasoline price trend periods

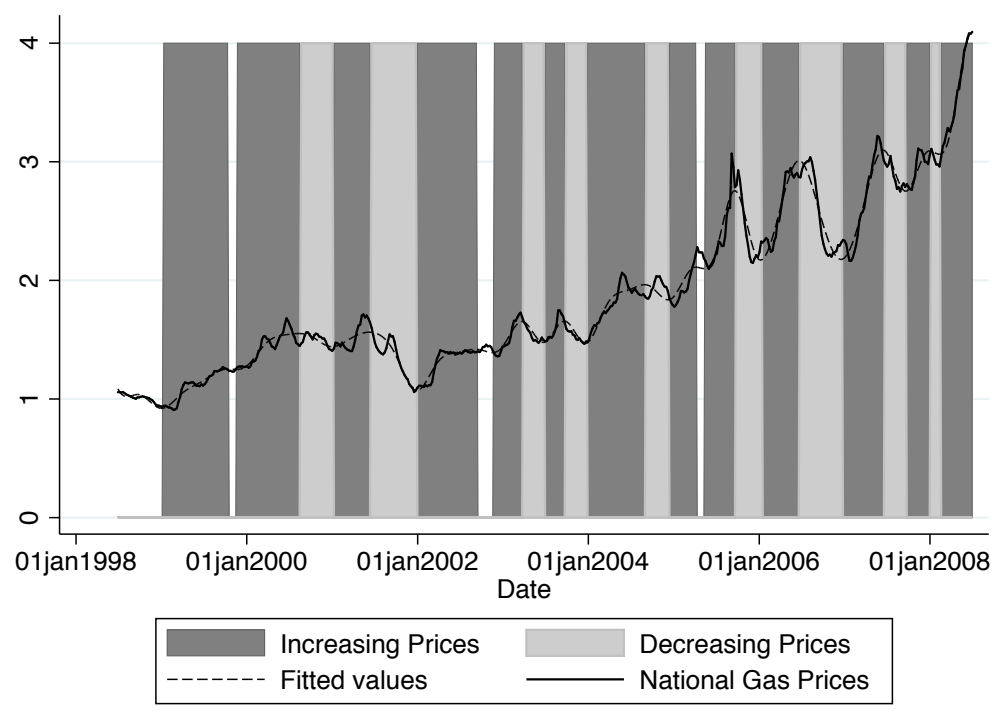

We then estimate the effect of gasoline prices on vehicle prices and market shares interacting GasolinePrice with an indicator variable for whether the observation occurred during a spell of increasing, decreasing, or "holding" gasoline prices.

In Table A-22, we report the effect of gasoline prices on vehicle prices, and in Table A-23 we report the effect of gasoline prices on market shares. In Table A-22, we find that in both new and used markets vehicle prices respond more to gasoline prices when prices have been recently increasing or decreasing than when they have been "holding," although the differences are not large. The most noteworthy result in the table, however, is that there is little difference in the estimated effects between periods of increasing and decreasing gasoline prices. We draw a similar conclusion about the effect of gasoline prices on market shares. There are differences (usually tenths of a percentage point) in the market share results across price trend regimes, but it is difficult to find a coherent way to characterize the differences.

\subsection{Heterogeneity by vehicle segment}

In the results so far, we have categorized vehicles by fuel economy bins. While this categorization sorts vehicles rigidly by fuel economy, it groups different kinds of vehicles within a single bin. An alternative would be to sort vehicles by segment. This would group together vehicles that are similar on a variety of characteristics, although with potentially greater heterogeneity among vehicles in fuel economy.

Our data source sorts vehicles into seven different segments (Compact, Midsize, Luxury, Sporty, 
SUV, Pickup, and Van). Each segment is divided into two to four subsegments. For example, Compact cars are divided into Entry Compact (such as the Hyundai Accent) and Premium Compact (such as the Honda Civic); SUVs are divided into Entry SUV (Ford Escape), Midsize SUV (Toyota 4Runner), Fullsize SUV (GMC Yukon), and Luxury SUV (Cadillac Escalade). Table A-24 lists each segment and subsegment, reporting average MPG within the segment or subsegment, and representative vehicles in each subsegment.

We repeat the base regressions that estimate the effect of gasoline prices on new vehicle prices, used vehicle prices, new vehicle sales, and used vehicle sales, but interacting GasolinePrice with indicators for vehicle segment or subsegment instead of with MPG Bin indicators. The results are reported in Tables A-25, A-26, A-27, and A-28. The most interesting results are the results for subsegments, reported in the second column of each table. In many cases, we see the same pattern we saw across MPG bins repeated within a particular segment. For example, in Tables A-25 and A-26, an increase in gasoline prices is associated with an increase in the price of Entry SUVs, but with decreases in the price of Midsize SUVs, and even larger decreases for Fullsize and Luxury SUVs. A similar effect occurs within the pickup segment: the price of Compact Pickups increases or stays unchanged when gasoline prices increase, but the price of Fullsize Pickups decreases. The sales estimates in Tables A-27 and A-28 show complementary effects: when gasoline prices increase, sales of Fullsize SUVs decrease by more than sales of Midsize SUVs, which decrease more than sales of Entry SUVs.

While it would be far from correct to claim that the pattern of larger effects for lower fuel economy vehicles holds within each segment, there are patterns that are consistent with substitution within segments; for example, that buyers substitute from larger SUVs to smaller SUVs, or from Fullsize Pickups to Compact Pickups.

\section{Concluding remarks}

In this paper we have investigated the effect of gasoline prices on market shares, unit sales, and prices of vehicles of different fuel economies in both the used and new vehicle markets. We have found statistically and economically significant effects in both markets. In new vehicle markets, gasoline prices have a large effect on market shares, and more modest effects on prices. We estimate the market share of vehicles with at least 24 MPG increases by $28.7 \%$ when gasoline prices increase by $\$ 1$, and the market share of the vehicles with less than 16 MPG falls by $22.8 \%$. Transaction prices for the highest fuel economy vehicles increase by $\$ 657$ relative to the lowest fuel economy vehicles.

In used vehicle markets, the transactions prices of the lowest fuel economy vehicles are estimated 
to fall by $\$ 1,474$ when gasoline prices rise by $\$ 1$, while the prices of the highest fuel economy used vehicles are estimated to rise by $\$ 922$, a difference of almost $\$ 2400$, an effect that is almost four times the effect estimated for new vehicles. We also estimate the effect of gasoline prices on the share of transactions at new vehicle dealerships which are for used vehicles of different fuel economies. We find changes of several percentage points, much smaller effects than the market share effects estimated for new vehicles.

We believe that there are several things we learn from these results. First, these results help us understand at least part of what happened in the U.S. auto industry over the last decade to bring it to the brink of bankruptcy in 2008. One might argue that the auto industry has experienced a "perfect storm" that included a credit crunch and a major recession as well as historically large increases in gasoline prices. While this paper cannot address all of these contributing factors, we believe we have learned something about the role of gasoline prices. In particular, we have shown that the big differences in sales mixes across manufacturers imply that gasoline price changes will have very different effects on the revenues of different manufacturers and on the net revenues of their affiliated dealer networks. In particular, increasing gasoline prices in the mid-2000's would have hit U.S. manufacturers (with their strong reliance on SUVs and pickups) particularly hard. The dealer networks affiliated with U.S. manufacturers would also have seen their net revenues fall because of increasing gasoline prices, despite evidence that manufacturers made some efforts to insulate their dealerships from these effects. Asian manufacturers, with stronger portfolios of high fuel economy cars than their U.S. competitors, still experience revenue decreases when gasoline prices increase, but this is the result primarily of overall unit sales declines, partially mitigated by shifts in market share that favor their high-fuel economy vehicles. Finally, we find that used vehicle sales help to counteract for dealerships some of the negative effects of gasoline price increases, but only if the dealerships sell high fuel economy used vehicles. The net revenues of a dealership whose used vehicle sales were concentrated in sales of one of the U.S. manufacturers' vehicles would be predicted to see the net revenues from sales of those vehicles fall if gasoline prices increased, compounding rather than mitigating the new vehicle effects.

The second lesson to learn from these results is that gasoline prices have very different effects in new and for used vehicle markets. We argue that the dramatic difference in how usage cost affects new and used automobile markets can be explained by differences in the supply of new and used cars. The auto manufacturers (and affiliated dealer networks) who supply new cars have some choice in determining how to respond to a change in demand: by changing prices, allowing quantities to change, or a mix of the two. The optimal response will depend on the shape of the demand and marginal cost curves, and on the extent of market power the suppliers have. In used vehicle markets, the ultimate buyers and sellers of used vehicles are drivers, whose valuations of the 
car will both change (and may change similarly) when gasoline prices change. This characteristic of the market - combined with an efficient wholesale market for used cars-appears to lead to rapid price adjustment for used cars, while new car manufacturers choose not to change prices, and experience market share changes instead. In this paper, we have investigated the implication of these effects for the revenues of auto manufacturers and net revenues of dealerships. However, these results have broader implications as well. One implication is for understanding the effect of environmental policy instruments in markets with different market structures, as discussed in Section 6.3. Another implication is for macroeconomists who are interested in the question of how oil prices affect the economy broadly (Kilian (2008), Barsky and Kilian (2004)). These results suggest that the effect of energy prices on markets for one of the major durable goods in the economy depends on the market structure of the market. 


\section{References}

Allcott, H., And N. Wozny (2011): "Gasoline Prices, Fuel Economy, and the Energy Paradox," Discussion paper, New York University.

Anderson, S. T., R. Kellogg, and J. M. Sallee (2011): "What Do Consumers Believe about Future Gasoline Prices?," Discussion Paper 16974, National Bureau of Economic Research.

Barsky, R. B., And L. Kilian (2004): "Oil and the Macroeconomy since the 1970s," Journal of Economic Perspectives, 18(4), 115-134.

Berry, S., J. Levinsohn, And A. Pakes (1995): "Automobile Prices in Market Equilibrium," Econometrica, 63(4), 841-890.

Busse, M. R. (2012): "When Supply and Demand Just Won't Do: Using the Equilibrium Locus to Think about Comparative Statics," Discussion paper, Northwestern University.

Busse, M. R., And N. O. Keohane (2007): "Market Effects of Environmental Regulation: Coal, Railroads, and the 1990 Clean Air Act," RAND Journal of Economics, 38(4), 1159-1179.

Busse, M. R., C. R. Knittel, and F. Zettelmeyer (forthcoming): "Are Consumers Myopic? Evidence from New and Used Car Purchases," American Economic Review.

Fowlie, M. (2010): "Emissions Trading, Electricity Restructuring, and Investment in Pollution Abatement," American Economic Review, 100, 837-869.

Kahn, J. (1986): "Gasoline Prices and the Used Automobile Market: A Rational Expectations Asset Price Approach," Quarterly Journal of Economics, 101(2), 323-340.

KiLIAn, L. (2008): "The Economic Effects of Energy Price Shocks," Journal of Economic Literature, 46(4), 871-909.

Klier, T., And J. Linn (2010): "The Price of Gasoline and New Vehicle Fuel Economy: Evidence from Monthly Sales Data," American Economic Journal: Economic Policy, 2(3), 134-153.

Knittel, C. R. (2011): "Automobiles on Steroids: Product Attribute Trade-offs and Technological Progress in the Automobile Sector," American Economic Review, 101(7), 3368-3399.

Li, S., C. Timmins, and R. von Haefen (2009): "How Do Gasoline Prices Affect Fleet Fuel Economy?," American Economic Journal: Economic Policy, 1(2), 113-137.

Mansur, E. T. (2007): "Do Oligopolists Pollute Less? Evidence from a Restructured Electricity Market," Journal of Industrial Economics, 55(4), 661-689.

Sallee, J. M., S. E. West, and W. FAn (2009): "Consumer Valuation of Fuel Economy: A Microdata Approach," Discussion paper, National Tax Association Conference Proceedings.

Verboven, F. (2002): "Quality-based Price Discrimination and Tax Incidence - The Market for Gasoline and Diesel Cars in Europe," RAND Journal of Economics, 33(2), 275-297. 


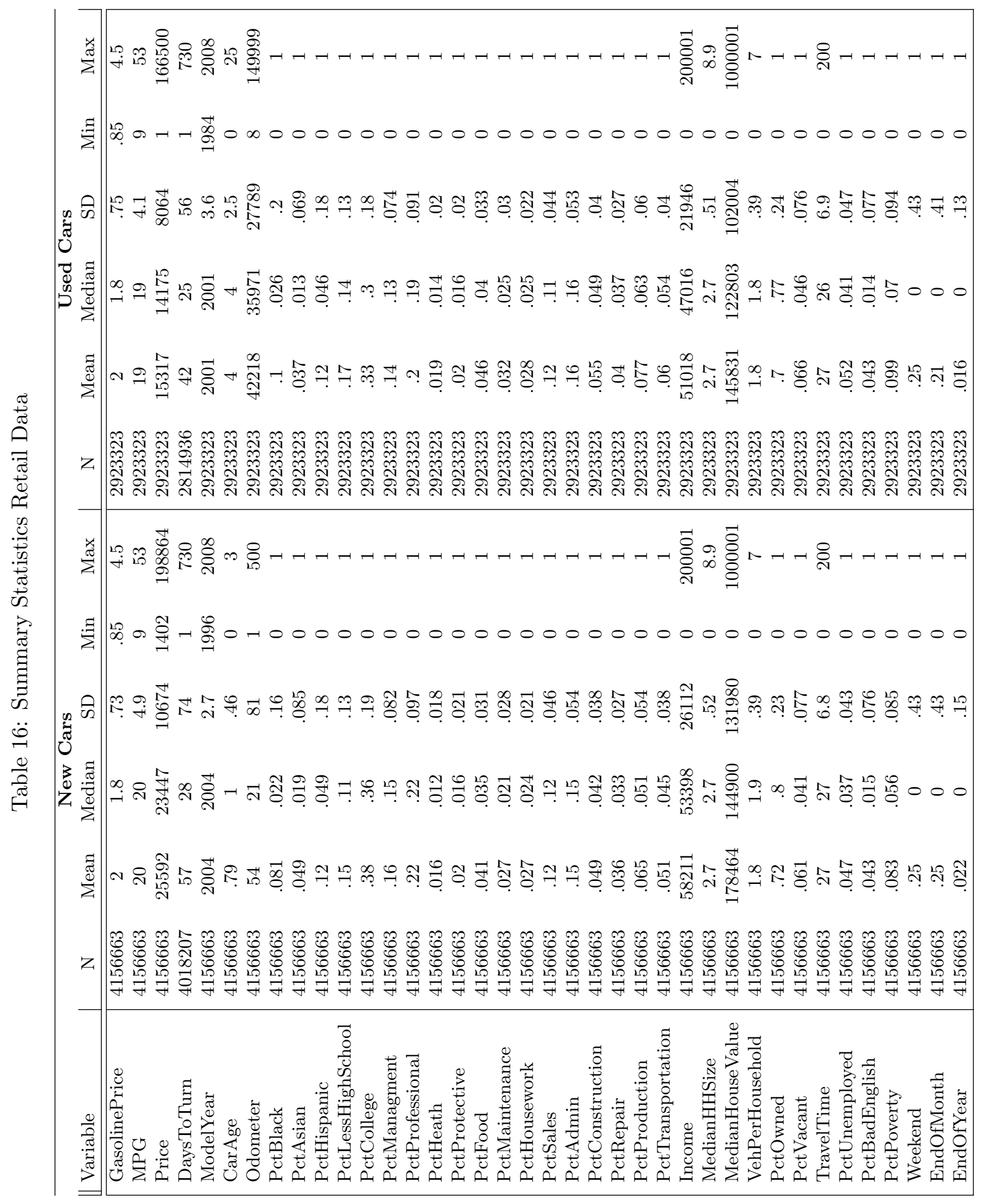


Table A-1: New Cars: Market share results, fuel economy bins ${ }^{\dagger}$

\begin{tabular}{|l||c|c|c|c|c|}
\hline & MPG Bin 1 & MPG Bin 2 & MPG Bin 3 & MPG Bin 4 & MPG Bin 5 \\
\hline \hline FuelPrice & $-.042^{* *}$ & $-.029^{* *}$ & $-.0037^{*}$ & $.015^{* *}$ & $.059^{* *}$ \\
& $(.004)$ & $(.0028)$ & $(.0016)$ & $(.003)$ & $(.0029)$ \\
\hline PctLessHighSchool & .022 & $.029^{* *}$ & .0037 & -.0075 & $-.047^{*}$ \\
& $(.016)$ & $(.0091)$ & $(.0081)$ & $(.01)$ & $(.019)$ \\
\hline PctCollege & $-.064^{* *}$ & -.0062 & $.027^{* *}$ & $.037^{* *}$ & .0067 \\
& $(.014)$ & $(.0089)$ & $(.0076)$ & $(.012)$ & $(.016)$ \\
\hline Income & $9.4 \mathrm{e}-09$ & $2.7 \mathrm{e}-07^{*}$ & $2.9 \mathrm{e}-07^{* *}$ & $-1.2 \mathrm{e}-07$ & $-4.4 \mathrm{e}-07^{* *}$ \\
& $(9.3 \mathrm{e}-08)$ & $(1.0 \mathrm{e}-07)$ & $(6.5 \mathrm{e}-08)$ & $(8.5 \mathrm{e}-08)$ & $(1.3 \mathrm{e}-07)$ \\
\hline MedianHHSize & $.01^{* *}$ & .0019 & -.004 & $-.0088^{*}$ & .00045 \\
& $(.0021)$ & $(.002)$ & $(.0031)$ & $(.0033)$ & $(.0052)$ \\
\hline MedianHouseValue & $2.5 \mathrm{e}-08$ & $6.7 \mathrm{e}-08^{* *}$ & $3.2 \mathrm{e}-08^{* *}$ & $-6.4 \mathrm{e}-08^{* *}$ & $-6.0 \mathrm{e}-08$ \\
& $(3.3 \mathrm{e}-08)$ & $(2.3 \mathrm{e}-08)$ & $(5.7 \mathrm{e}-09)$ & $(1.5 \mathrm{e}-08)$ & $(4.1 \mathrm{e}-08)$ \\
\hline VehiclePerHH & -.0031 & .021 & -.013 & -.014 & .0094 \\
& $(.021)$ & $(.017)$ & $(.014)$ & $(.016)$ & $(.018)$ \\
\hline TravelTime & -.000038 & $-.00029+$ & $-.00023^{*}$ & -.000012 & $.00057^{*}$ \\
& $(.00017)$ & $(.00016)$ & $(.000087)$ & $(.00011)$ & $(.00026)$ \\
\hline Weekend & $-.018^{* *}$ & $-.0045^{* *}$ & -.00023 & $.0063^{* *}$ & $.017^{* *}$ \\
& $(.0014)$ & $(.0015)$ & $(.00093)$ & $(.0016)$ & $(.002)$ \\
\hline EndOfMonth & $.0051^{* *}$ & $.0034^{* *}$ & $.0028^{* *}$ & -.00067 & $-.011^{* *}$ \\
& $(.00059)$ & $(.00088)$ & $(.00059)$ & $(.00057)$ & $(.0008)$ \\
\hline EndOfYear & $-.004^{*}$ & $-.0045^{*}$ & $-.0029^{*}$ & $.0066^{* *}$ & $.0047^{*}$ \\
& $(.0016)$ & $(.0017)$ & $(.0011)$ & $(.0017)$ & $(.002)$ \\
\hline Constant & $.32^{* *}$ & $.29^{* *}$ & $.21^{* *}$ & $.18^{* *}$ & -.0012 \\
& $(.021)$ & $(.013)$ & $(.0072)$ & $(.007)$ & $(.0098)$ \\
\hline Observations & 4156663 & 4156663 & 4156663 & 4156663 & 4156663 \\
\hline R-squared & 0.023 & 0.006 & 0.007 & 0.008 & 0.036 \\
\hline
\end{tabular}

${ }^{*}$ significant at 5\%; ** significant at 1\%; + significant at $10 \%$ level. Standard errors (robust and clustered at the region level) in parentheses.

Not reported: Region $\times$ month-of-year and region $\times$ year fixed effects. We also don't report house ownership, occupation, English proficiency, and race of buyers. 
Table A-2: New Cars: Equilibrium sales response to gasoline prices

\begin{tabular}{|l||c|c|c|c|c|}
\hline Dep. Var: Sales & MPG Bin 1 & MPG Bin 2 & MPG Bin 3 & MPG Bin 4 & MPG Bin 5 \\
\hline \hline FuelPrice & $-10084^{* *}$ & $-7422^{* *}$ & $-4705^{* *}$ & $-2155+$ & $4974^{* *}$ \\
& $(1076)$ & $(1244)$ & $(1228)$ & $(1275)$ & $(1108)$ \\
\hline Constant & $25067^{* *}$ & $19902^{* *}$ & $17954^{* *}$ & $26738^{* *}$ & $4291^{* *}$ \\
& $(1385)$ & $(1456)$ & $(1821)$ & $(2801)$ & $(1499)$ \\
\hline Observations & 882 & 882 & 882 & 882 & 882 \\
\hline R-squared & 0.953 & 0.961 & 0.962 & 0.963 & 0.973 \\
\hline
\end{tabular}

${ }^{*}$ significant at $5 \% ;{ }^{* *}$ significant at $1 \%$; significant at $10 \%$ level. Standard errors in parentheses are robust.

Not reported: PADD $\times$ year fixed effects and PADD $\times$ month-of-year fixed effects. 
Table A-3: New Cars: Equilibrium price response to gasoline prices

\begin{tabular}{|c|c|}
\hline Variable & Coefficient (SE) \\
\hline "GasolinePrice*MPG Bin 1 & $\begin{array}{c}-362^{* *} \\
(89)\end{array}$ \\
\hline GasolinePrice*MPG Bin 2 & $\begin{array}{c}-159^{* *} \\
(31)\end{array}$ \\
\hline GasolinePrice*MPG Bin 3 & $\begin{array}{l}-20 \\
(33)\end{array}$ \\
\hline GasolinePrice*MPG Bin 4 & $\begin{array}{c}137^{* *} \\
(36)\end{array}$ \\
\hline GasolinePrice*MPG Bin 5 & $\begin{array}{c}295^{* *} \\
(32)\end{array}$ \\
\hline PctLessHighSchool & $\begin{array}{l}171^{*} \\
(79)\end{array}$ \\
\hline PctCollege & $\begin{array}{c}81 \\
(56)\end{array}$ \\
\hline Income & $\begin{array}{l}.0015^{* *} \\
(.00032)\end{array}$ \\
\hline MedianHHSize & $\begin{array}{l}61^{* *} \\
(15)\end{array}$ \\
\hline MedianHouseValue & $\begin{array}{c}.000083 \\
(.000091)\end{array}$ \\
\hline VehiclePerHH & $\begin{array}{l}220+ \\
(109)\end{array}$ \\
\hline TravelTime & $\begin{array}{l}.033 \\
(.84)\end{array}$ \\
\hline Weekend & $\begin{array}{l}4.9 \\
(6)\end{array}$ \\
\hline EndOfMonth & $\begin{array}{c}-122^{* *} \\
(2.8)\end{array}$ \\
\hline EndOfYear & $\begin{array}{c}-61^{* *} \\
(7.4)\end{array}$ \\
\hline Constant & $\begin{array}{c}32853^{* *} \\
(117)\end{array}$ \\
\hline Observations & 4156663 \\
\hline R-squared & 0.046 \\
\hline \multicolumn{2}{|c|}{$\begin{array}{l}\text { * significant at } 5 \% ; * * \text { significant at } 1 \% \text {; }+ \\
\text { significant at } 10 \% \text { level. Standard errors in } \\
\text { parentheses are robust and clustered at the re- } \\
\text { gion level. } \\
\text { Not reported: Region } \times \text { month-of-year, region } \\
\times \text { year, and vehicle type fixed effects. We also } \\
\text { don't report house ownership, occupation, En- } \\
\text { glish proficiency, and race of buyers. }\end{array}$} \\
\hline
\end{tabular}


Table A-4: Used Cars: Retail and wholesale prices ${ }^{\dagger}$

\begin{tabular}{|c|c|c|}
\hline & Retail & Wholesale \\
\hline FuelPrice*MPG Bin 1 & $\begin{array}{c}-1474^{* *} \\
(40)\end{array}$ & $\begin{array}{c}-1444^{* *} \\
(37)\end{array}$ \\
\hline FuelPrice*MPG Bin 2 & $\begin{array}{c}-356^{* *} \\
(48)\end{array}$ & $\begin{array}{c}-318^{* *} \\
(43)\end{array}$ \\
\hline FuelPrice*MPG Bin 3 & $\begin{array}{c}313^{* *} \\
(21)\end{array}$ & $\begin{array}{c}323^{* *} \\
(24)\end{array}$ \\
\hline FuelPrice*MPG Bin 4 & $\begin{array}{c}745^{* *} \\
(24)\end{array}$ & $\begin{array}{c}720^{* *} \\
(26)\end{array}$ \\
\hline FuelPrice*MPG Bin 5 & $\begin{array}{c}922^{* *} \\
(24)\end{array}$ & $\begin{array}{c}849^{* *} \\
(22)\end{array}$ \\
\hline PctLessHighSchool & $\begin{array}{c}239^{* *} \\
(56)\end{array}$ & $\begin{array}{c}233^{* *} \\
(68)\end{array}$ \\
\hline PctCollege & $\begin{array}{c}57 \\
(44)\end{array}$ & $\begin{array}{l}95^{*} \\
(39)\end{array}$ \\
\hline Income & $\begin{array}{l}.0011+ \\
(.0006) \\
\end{array}$ & $\begin{array}{c}.0014^{*} \\
(.00062) \\
\end{array}$ \\
\hline MedianHHSize & $\begin{array}{l}41+ \\
(21)\end{array}$ & $\begin{array}{l}-4.6 \\
(24)\end{array}$ \\
\hline MedianHouseValue & $\begin{array}{c}.00012 \\
(.00017) \\
\end{array}$ & $\begin{array}{c}.00011 \\
(.00013) \\
\end{array}$ \\
\hline VehiclePerHH & $\begin{array}{c}23 \\
(94)\end{array}$ & $\begin{array}{l}-78 \\
(77)\end{array}$ \\
\hline TravelTime & $\begin{array}{l}.74 \\
(.66)\end{array}$ & $\begin{array}{l}-.18 \\
(.88)\end{array}$ \\
\hline Weekend & $\begin{array}{c}105^{* *} \\
(11)\end{array}$ & $\begin{array}{l}41^{* *} \\
(9.7)\end{array}$ \\
\hline EndOfMonth & $\begin{array}{c}-71^{* *} \\
(3.7)\end{array}$ & $\begin{array}{c}-36^{* *} \\
(2.9)\end{array}$ \\
\hline EndOfYear & $\begin{array}{c}20 \\
(13)\end{array}$ & $\begin{array}{c}8.2 \\
(12)\end{array}$ \\
\hline Constant & $\begin{array}{c}26234^{* *} \\
(258)\end{array}$ & $\begin{array}{c}24881^{* *} \\
(200)\end{array}$ \\
\hline Observations & 2923323 & 2923323 \\
\hline R-squared & 0.728 & 0.739 \\
\hline Relative price difference b/w MPG bin 5 and 1 : & $\$ 2396$ & $\$ 2293$ \\
\hline
\end{tabular}

${ }^{*}$ significant at $5 \%$; ${ }^{*}$ significant at $1 \%$; significant at $10 \%$ level. Standard errors (robust and clustered at the region level) in parentheses.

Not reported: Region $\times$ mont-of-year fixed effects, PADD $\times$ segment $\times$ year fixed effects, vehicle type fixed effects, and odometer spline. We also don't report house ownership, occupation, English proficiency, and race of buyers. 
Table A-5: Used Cars: Market share results, fuel economy bins ${ }^{\dagger}$

\begin{tabular}{|l||c|c|c|c|c|}
\hline & MPG Bin 1 & MPG Bin 2 & MPG Bin 3 & MPG Bin 4 & MPG Bin 5 \\
\hline \hline FuelPrice & $-.01^{* *}$ & $.0021+$ & -.00025 & $.0043^{* *}$ & $.0039^{* *}$ \\
& $(.0015)$ & $(.0012)$ & $(.0015)$ & $(.0011)$ & $(.00089)$ \\
\hline PctLessHighSchool & .0027 & -.0067 & -.00021 & .0052 & -.00096 \\
& $(.0069)$ & $(.0068)$ & $(.0074)$ & $(.0058)$ & $(.0067)$ \\
\hline PctCollege & $-.014^{*}$ & $-.05^{* *}$ & .0032 & $.043^{* *}$ & $.017^{* *}$ \\
& $(.0062)$ & $(.0052)$ & $(.0049)$ & $(.0066)$ & $(.0047)$ \\
\hline Income & $-1.1 \mathrm{e}-09$ & $1.8 \mathrm{e}-07^{* *}$ & $3.5 \mathrm{e}-08$ & $-1.8 \mathrm{e}-07^{* *}$ & $-3.3 \mathrm{e}-08$ \\
& $(4.6 \mathrm{e}-08)$ & $(3.4 \mathrm{e}-08)$ & $(3.8 \mathrm{e}-08)$ & $(3.2 \mathrm{e}-08)$ & $(2.8 \mathrm{e}-08)$ \\
\hline MedianHHSize & $.0061^{* *}$ & $-.0048^{* *}$ & $-.0018+$ & -.00017 & .00062 \\
& $(.0011)$ & $(.00085)$ & $(.0009)$ & $(.0012)$ & $(.00075)$ \\
\hline MedianHouseValue & $2.6 \mathrm{e}-08+$ & $1.2 \mathrm{e}-08+$ & $-3.6 \mathrm{e}-08^{* *}$ & $4.0 \mathrm{e}-09$ & $-6.8 \mathrm{e}-09$ \\
& $(1.4 \mathrm{e}-08)$ & $(7.4 \mathrm{e}-09)$ & $(6.4 \mathrm{e}-09)$ & $(6.7 \mathrm{e}-09)$ & $(4.6 \mathrm{e}-09)$ \\
\hline VehiclePerHH & -.017 & .00068 & .021 & -.009 & .0047 \\
& $(.018)$ & $(.017)$ & $(.016)$ & $(.011)$ & $(.0095)$ \\
\hline TravelTime & $-.00013+$ & -.000043 & -.000032 & $.00015^{*}$ & .000056 \\
& $(.000076)$ & $(.000057)$ & $(.000051)$ & $(.00006)$ & $(.000043)$ \\
\hline Weekend & $-.0061^{* *}$ & -.00035 & $.0015^{*}$ & $.0026^{* *}$ & $.0023^{* *}$ \\
& $(.00056)$ & $(.00072)$ & $(.00061)$ & $(.00058)$ & $(.00029)$ \\
\hline EndOfMonth & .00091 & $-.0017^{*}$ & .00068 & -.00065 & $.00075+$ \\
& $(.00056)$ & $(.00063)$ & $(.00064)$ & $(.00067)$ & $(.00042)$ \\
\hline EndOfYear & $-.0056^{* *}$ & .0031 & -.0014 & .0024 & .0015 \\
& $(.0015)$ & $(.002)$ & $(.0015)$ & $(.0018)$ & $(.0012)$ \\
\hline Constant & $.042^{* *}$ & .0074 & -.015 & $.12^{* *}$ & $.84^{* *}$ \\
& $(.0079)$ & $(.012)$ & $(.012)$ & $(.03)$ & $(.027)$ \\
\hline Observations & 2986570 & 2986570 & 2986570 & 2986570 & 2986570 \\
\hline R-squared & 0.384 & 0.217 & 0.146 & 0.343 & 0.595 \\
\hline
\end{tabular}

${ }^{*}$ significant at $5 \%$;** significant at $1 \%$; significant at $10 \%$ level. Standard errors (robust and clustered at the region level) in parentheses.

Not reported: Region $\times$ mont-of-year, PADD $\times$ segment $\times$ year fixed effects, and odometer spline. We also don't report house ownership, occupation, English proficiency, and race of buyers.

Table A-6: Used Cars: Equilibrium sales response to gasoline prices

\begin{tabular}{|l||c|c|c|c|c|}
\hline Dep. Var: Sales & MPG Bin 1 & MPG Bin 2 & MPG Bin 3 & MPG Bin 4 & MPG Bin 5 \\
\hline \hline FuelPrice & $-3857^{* *}$ & $-2406^{* *}$ & -790 & 134 & 375 \\
& $(597)$ & $(627)$ & $(605)$ & $(743)$ & $(598)$ \\
\hline Constant & $11470^{* *}$ & $12394^{* *}$ & $9046^{* *}$ & $14246^{* *}$ & $7979^{* *}$ \\
& $(705)$ & $(845)$ & $(766)$ & $(1396)$ & $(922)$ \\
\hline Observations & 882 & 882 & 882 & 882 & 882 \\
\hline R-squared & 0.978 & 0.979 & 0.976 & 0.950 & 0.927 \\
\hline
\end{tabular}

${ }^{*}$ significant at $5 \%$;* significant at $1 \% ;+$ significant at $10 \%$ level. Standard errors in parentheses are robust.

Not reported: PADD $\times$ year fixed effects and PADD $\times$ month-of-year fixed effects. 
Table A-7: New and Used Cars: Inventory results ${ }^{\dagger}$

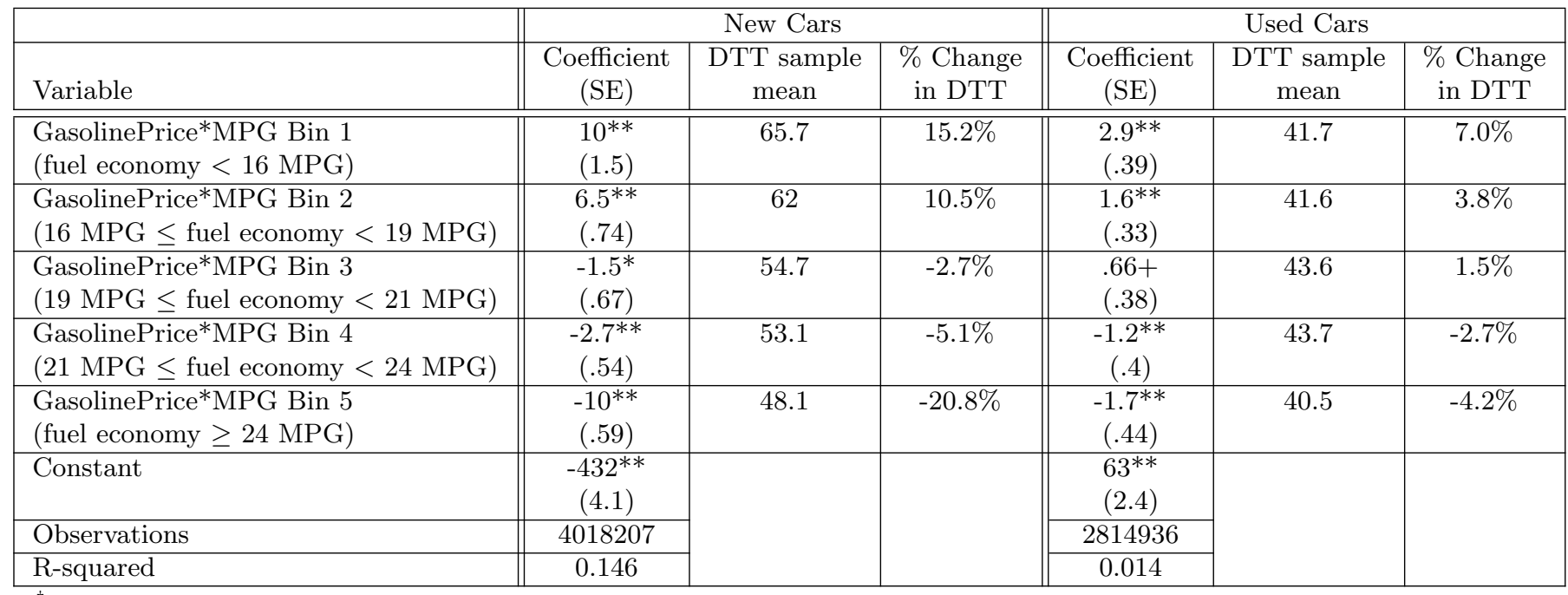

${ }^{\dagger}$ This table only reports the coefficients on gasoline prices. The full specification for both new and used cars is:

$$
D T T_{i r d j t}=\omega_{0}+\omega_{1}\left(\text { GasolinePrice }_{i t} \cdot \mathrm{MPG} \text { Quartile }_{j}\right)+\tau_{r t}+\mu_{r t}+\delta_{d j}+\nu_{i j t}
$$

where $D T T_{i r d j t}$ measures days to turn for transaction $i$ in region $r$ at dealer $d$ on date $t$ for car $j$. We use the same time and region controls we have used in the market share specification with one addition. To control for the fact that different dealerships may have different inventory policies we include car type $\times$ dealer fixed effects $\left(\delta_{d j}\right)$.

* significant at $5 \% ;{ }^{* *}$ significant at $1 \% ;+$ significant at $10 \%$ level. Standard errors (robust and clustered at the region level) in parentheses.

Table A-8: New Cars: Equilibrium sales response to gasoline prices by origin

\begin{tabular}{|c|c|c|c|c|c|c|c|c|c|}
\hline Variable & \multicolumn{3}{|c|}{ Asia } & \multicolumn{3}{|c|}{ Europe } & \multicolumn{3}{|c|}{ U.S. } \\
\hline $\begin{array}{l}\text { GasPrice*MPG Bin 1 } \\
\text { (fuel economy }<16 \mathrm{MPG} \text { ) }\end{array}$ & $\begin{array}{c}-796^{* *} \\
(142)\end{array}$ & 3551 & $-22 \%$ & $\begin{array}{c}-231^{* *} \\
(35)\end{array}$ & 513 & $-45 \%$ & $\begin{array}{c}-9032^{* *} \\
(1061)\end{array}$ & 31752 & $-28 \%$ \\
\hline $\begin{array}{l}\text { GasPrice* MPG Bin 3 } \\
(19 \mathrm{MPG} \leq \mathrm{FE}<21 \mathrm{MPG})\end{array}$ & $\begin{array}{c}-2259^{* *} \\
(404)\end{array}$ & 10003 & $-23 \%$ & $\begin{array}{c}-342^{* *} \\
(120)\end{array}$ & 2719 & $-13 \%$ & $\begin{array}{c}-1490^{*} \\
(623)\end{array}$ & 17113 & $-9 \%$ \\
\hline $\begin{array}{l}\text { GasPrice* MPG Bin 5 } \\
\text { (fuel economy } \geq 24 \mathrm{MPG} \text { ) }\end{array}$ & $(524)$ & 19422 & $22 \%$ & $\begin{array}{c}481^{* *} \\
(63)\end{array}$ & 1021 & $47 \%$ & $\begin{array}{c}98 \\
(516)\end{array}$ & 10603 & $1 \%$ \\
\hline
\end{tabular}

${ }^{*}$ significant at $5 \%$; ${ }^{* *}$ significant at $1 \%$; significant at $10 \%$ level. Standard errors in parentheses are robust and clustered at the region level.

This table only reports the coefficients on gasoline prices. Full results are available upon request from the authors. 
Table A-9: New cars: Equilibrium price response to gasoline prices by origin

\begin{tabular}{|c|c|c|c|}
\hline Variable & $\begin{array}{c}\text { Asia } \\
\text { Coefficient (SE) }\end{array}$ & $\begin{array}{c}\text { Europe } \\
\text { Coefficient (SE) }\end{array}$ & $\begin{array}{c}\text { U.S. } \\
\text { Coefficient (SE) }\end{array}$ \\
\hline $\begin{array}{l}\text { GasolinePrice*MPG Bin } \mathbf{1}^{\dagger} \\
\text { (fuel economy }<16 \mathrm{MPG} \text { ) }\end{array}$ & $\begin{array}{c}-363^{* *} \\
(71)\end{array}$ & $\begin{array}{c}-802^{* *} \\
(264)\end{array}$ & $\begin{array}{l}-318^{*} \\
(124)\end{array}$ \\
\hline $\begin{array}{l}\text { GasolinePrice* MPG Bin } 2 \\
(16 \mathrm{MPG} \leq \text { fuel economy }<19 \mathrm{MPG})\end{array}$ & $\begin{array}{c}-207^{* *} \\
(33)\end{array}$ & $\begin{array}{c}-781^{* *} \\
(172)\end{array}$ & $\begin{array}{l}-30 \\
(50)\end{array}$ \\
\hline $\begin{array}{l}(19 \mathrm{MPG} \leq \text { fuel economy }<21 \mathrm{MPG}) \\
\end{array}$ & $\begin{array}{c}-65+ \\
(32)\end{array}$ & $\begin{array}{r}-149 \\
(149)\end{array}$ & $\begin{array}{c}162^{* *} \\
(40)\end{array}$ \\
\hline $\begin{array}{l}\text { GasolinePrice* MPG Bin } \\
(21 \mathrm{MPG} \leq \text { fuel economy }<24 \mathrm{MPG})\end{array}$ & $\begin{array}{c}159^{* *} \\
(43)\end{array}$ & $(98)$ & $\begin{array}{c}260^{* *} \\
(31)\end{array}$ \\
\hline $\begin{array}{l}\text { GasolinePrice* MPG Bin } \mathbf{5} \\
\text { (fuel economy } \geq 24 \mathrm{MPG} \text { ) }\end{array}$ & $\begin{array}{c}272^{* *} \\
(37)\end{array}$ & $\begin{array}{c}527^{* *} \\
(82)\end{array}$ & $\begin{array}{c}319^{* *} \\
(53)\end{array}$ \\
\hline Price difference between highest and lowest MPG Bin: & $\$ 635$ & $\$ 1,329$ & $\$ 637$ \\
\hline
\end{tabular}

* significant at $5 \% ;{ }^{* *}$ significant at $1 \%$ + significant at $10 \%$ level. Standard errors in parentheses are robust and clustered at the region level.

This table only reports the coefficients on gasoline prices. Full results are available upon request from the authors.

Table A-10: New cars: Equilibrium wholesaleprice response to gasoline prices by origin

\begin{tabular}{|c|c|c|c|}
\hline Variable & $\begin{array}{c}\text { Asia } \\
\text { Coefficient (SE) }\end{array}$ & $\begin{array}{c}\text { Europe } \\
\text { Coefficient (SE) }\end{array}$ & $\begin{array}{c}\text { U.S. } \\
\text { Coefficient (SE) }\end{array}$ \\
\hline $\begin{array}{l}\text { GasolinePrice*MPG Bin } \mathbf{1}^{\dagger} \\
\text { (fuel economy }<16 \mathrm{MPG} \text { ) }\end{array}$ & $\begin{array}{c}-211^{*} \\
(80)\end{array}$ & $\begin{array}{l}-170 \\
(207)\end{array}$ & $\begin{array}{c}-395^{* *} \\
(81)\end{array}$ \\
\hline $\begin{array}{l}\text { GasolinePrice* MPG Bin } \\
(16 \mathrm{MPG} \leq \text { fuel economy }<19 \mathrm{MPG})\end{array}$ & $\begin{array}{c}-139^{* *^{-}} \\
(34)\end{array}$ & $\begin{array}{c}-169+ \\
(97)\end{array}$ & $\begin{array}{c}-90^{* *} \\
(28)\end{array}$ \\
\hline $\begin{array}{l}\text { GasolinePrice* MPG } 1 \text { Bin } \\
(19 \mathrm{MPG} \leq \text { fuel economy }<21 \mathrm{MPG})\end{array}$ & $\begin{array}{c}188^{* *} \\
(28)\end{array}$ & $\begin{array}{c}83^{-} \\
(111)\end{array}$ & $\begin{array}{c}113^{* *} \\
(28)\end{array}$ \\
\hline $\begin{array}{l}\text { GasolinePrice* MPG Bin } \\
(21 \mathrm{MPG} \leq \text { fuel economy }<24 \mathrm{MPG})\end{array}$ & $\begin{array}{c}269^{* *} \\
(37)\end{array}$ & $\begin{array}{c}2311^{* *} \\
(51)\end{array}$ & $\begin{array}{c}164^{* *} \\
(30)\end{array}$ \\
\hline $\begin{array}{l}\text { GasolinePrice* } \mathbf{M} \mathbf{P} \overline{\mathbf{B}} \mathbf{B} \mathbf{5} \\
\text { (fuel economy } \geq 24 \mathrm{MPG} \text { ) }\end{array}$ & $\begin{array}{c}184^{* *} \\
(37)\end{array}$ & $\begin{array}{c}364^{* *} \\
(51)\end{array}$ & $\begin{array}{c}202^{* *} \\
(48)\end{array}$ \\
\hline Price difference between highest and lowest MPG Bin: & $\$ 395$ & $\$ 534$ & $\$ 597$ \\
\hline
\end{tabular}

${ }^{*}$ significant at 5\%; ${ }^{* *}$ significant at $1 \% ;+$ significant at $10 \%$ level. Standard errors in parentheses are robust and clustered at the region level.

This table only reports the coefficients on gasoline prices. Full results are available upon request from the authors.

Table A-11: New cars: Equilibrium dealer margin response to gasoline prices by origin

\begin{tabular}{|c|c|c|c|}
\hline Variable & $\begin{array}{c}\text { Asia } \\
\text { Coefficient (SE) }\end{array}$ & $\begin{array}{c}\text { Europe } \\
\text { Coefficient (SE) }\end{array}$ & $\begin{array}{c}\text { U.S. } \\
\text { Coefficient (SE) }\end{array}$ \\
\hline 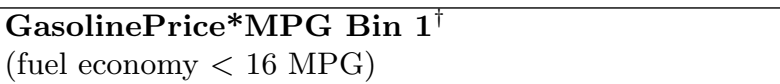 & $\begin{array}{c}-152^{* *} \\
(33)\end{array}$ & $\begin{array}{c}-632^{* *} \\
(123)\end{array}$ & $\begin{array}{c}78 \\
(51)\end{array}$ \\
\hline $\begin{array}{l}\text { GasolinePrice MPG Bin } \\
(16 \mathrm{MPG} \leq \text { fuel economy }<19 \mathrm{MPG})\end{array}$ & $\begin{array}{l}-68^{* *} *^{--} \\
(25)\end{array}$ & $\begin{array}{c}-612^{* *} \\
(143)\end{array}$ & $\begin{array}{l}61^{*} \\
(28)\end{array}$ \\
\hline $\begin{array}{l}\text { Gasoline } 19 \mathrm{MPG} \leq \text { fuel economy }<21 \mathrm{MPG})\end{array}$ & $\begin{array}{c}-252^{* *-} \\
(29)\end{array}$ & $\begin{array}{c}-232^{* *}- \\
(78)\end{array}$ & $\begin{array}{l}49^{--} \\
(32)\end{array}$ \\
\hline $\begin{array}{l}\text { Gasoline } \\
(21 \mathrm{MPG} \leq \text { fuel economy }<24 \mathrm{MPG})\end{array}$ & $\begin{array}{c}-110^{* *}{ }^{-} \\
(20)\end{array}$ & $\begin{array}{c}-11 \overline{4}+ \\
(57)\end{array}$ & $\begin{array}{l}97^{* *}{ }^{-} \\
(15)\end{array}$ \\
\hline $\begin{array}{l}\text { GasolinePrice* } \mathbf{M} \overline{P G} \text { Bin } \\
\text { fuel economy } \geq 24 \mathrm{MPG} \text { ) }\end{array}$ & $(27)$ & $\begin{array}{c}163^{* *} \\
(48)\end{array}$ & $\begin{array}{c}(17) \\
\left(177^{* *}\right.\end{array}$ \\
\hline Price difference between highest and lowest MPG Bin: & $\$ 240$ & $\$ 795$ & $\$ 39$ \\
\hline
\end{tabular}

${ }^{*}$ significant at $5 \% ;{ }^{* *}$ significant at $1 \%$; significant at $10 \%$ level. Standard errors in parentheses are robust and clustered at the region level.

This table only reports the coefficients on gasoline prices. Full results are available upon request from the authors. 
Table A-12: New Cars: Retail prices, wholesale prices, and dealer margins by MPG bin ${ }^{\dagger}$

\begin{tabular}{|c|c|c|c|c|c|c|c|}
\hline & Variable & MPG Bin 1 & MPG Bin 2 & MPG Bin 3 & MPG Bin 4 & MPG Bin 5 & Average \\
\hline \multirow[t]{3}{*}{ BMW } & Retail prices & $\$ 73,452$ & $\$ 58,797$ & $\$ 43,347$ & $\$ 42,032$ & $\$ 26,437$ & $\$ 44,641$ \\
\hline & Wholesale prices & $\$ 68,677$ & $\$ 56,120$ & $\$ 41,482$ & $\$ 40,394$ & $\$ 24,404$ & $\$ 42,544$ \\
\hline & Dealer margins & $\$ 4,774$ & $\$ 2,677$ & $\$ 1,865$ & $\$ 1,638$ & $\$ 2,033$ & $\$ 2,097$ \\
\hline \multirow[t]{3}{*}{ Chrysler } & Retail prices & $\$ \overline{2}, \overline{7} \overline{5}$ & $\$ 25,323$ & $\$ 23,323$ & $\$ 19,321$ & $\$ 15,718$ & $\$ 24,342$ \\
\hline & Wholesale prices & $\$ 25,495$ & $\$ 24,352$ & $\$ 22,282$ & $\$ 18,570$ & $\$ 15,026$ & $\$ 23,312$ \\
\hline & Dealer margins & $\$ 1,239$ & $\$ 971$ & $\$ 1,041$ & $\$ 751$ & $\$ 692$ & $\$ 1,030$ \\
\hline \multirow[t]{3}{*}{ Ford } & Retail prices & $\$ 28,925$ & $\$ 25,346$ & $\$ 23,259$ & $\$ 2 \overline{1}, \overline{1} \overline{2}$ & $\$ 16,521$ & $\$ 24,688$ \\
\hline & Wholesale prices & $\$ 27,587$ & $\$ 24,131$ & $\$ 22,227$ & $\$ 20,801$ & $\$ 15,720$ & $\$ 23,547$ \\
\hline & Dealer margins & $\$ 1,338$ & $\$ 1,216$ & $\$ 1,032$ & $\$ 911$ & $\$ 801$ & $\$ 1,141$ \\
\hline \multirow[t]{3}{*}{$\mathrm{GM}$} & Retail prices & $\$ \overline{3} \overline{2}, \overline{4} \overline{6}$ & $\$ 28,561$ & $\$ 29,113$ & $\overline{\$}^{-} \overline{0}, \overline{2} \overline{9}$ & $\$ 16,198$ & $\$ 26,610$ \\
\hline & Wholesale prices & $\$ 31,323$ & $\$ 27,226$ & $\$ 27,638$ & $\$ 19,251$ & $\$ 15,417$ & $\$ 25,305$ \\
\hline & Dealer margins & $\$ 1,622$ & $\$ 1,335$ & $\$ 1,475$ & $\$ 1,048$ & $\$ 782$ & $\$ 1,305$ \\
\hline \multirow{3}{*}{ Honda } & Retail prices & $\$ 30,966$ & $\$ 32,912$ & $\$ 29,447$ & $\$ \overline{2} \overline{3}, \overline{2} \overline{7}$ & $\$ 19,061$ & $\$ 23,570$ \\
\hline & Wholesale prices & $\$ 29,786$ & $\$ 30,997$ & $\$ 27,645$ & $\$ 22,801$ & $\$ 18,320$ & $\$ 22,432$ \\
\hline & Dealer margins & $\$ 1,180$ & $\$ 1,915$ & $\$ 1,802$ & $\$ 1,127$ & $\$ 742$ & $\$ 1,138$ \\
\hline \multirow[t]{3}{*}{ Hyundai } & Retail prices & $\$ \overline{2}, \overline{1} \overline{6}$ & $\$ 21,223$ & $\$ 20,843$ & $\$ \overline{1} \overline{3}, \overline{3} \overline{6}$ & $\$ 15,1 \overline{1}$ & $\$ 17,648$ \\
\hline & Wholesale prices & $\$ 22,281$ & $\$ 20,479$ & $\$ 20,132$ & $\$ 16,688$ & $\$ 14,661$ & $\$ 17,043$ \\
\hline & Dealer margins & $\$ 895$ & $\$ 744$ & $\$ 711$ & $\$ 678$ & $\$ 480$ & $\$ 605$ \\
\hline \multirow[t]{3}{*}{ Mazda } & Retail prices & $\$ 21,113$ & $\$ 24,963$ & $\$ 22,553$ & $\$ 19,934$ & $\$ 17,603$ & $\$ 20,621$ \\
\hline & Wholesale prices & $\$ 20,174$ & $\$ 24,067$ & $\$ 21,717$ & $\$ 19,187$ & $\$ 17,065$ & $\$ 19,901$ \\
\hline & Dealer margins & $\$ 939$ & $\$ 896$ & $\$ 836$ & $\$ 747$ & $\$ 538$ & $\$ 720$ \\
\hline \multirow[t]{3}{*}{ Mercedes } & Retail prices & $\$ 67,526$ & $\$ 60,833$ & $\$ 47,185$ & $\$ \overline{3} 9, \overline{1} \overline{4}$ & $\$ 51,988$ & $\$ 53,645$ \\
\hline & Wholesale prices & $\$ 64,871$ & $\$ 58,439$ & $\$ 45,843$ & $\$ 38,571$ & $\$ 49,889$ & $\$ 51,730$ \\
\hline & Dealer margins & $\$ 2,655$ & $\$ 2,394$ & $\$ 1,341$ & $\$ 1,343$ & $\$ 2,099$ & $\$ 1,915$ \\
\hline \multirow[t]{3}{*}{ Nissan } & Retail prices & $\$ \overline{3}, 0 \overline{1}$ & $\$ 27,829$ & $\$ 29,889$ & $\$ \overline{2} \overline{3}, 0 \overline{4}$ & $\$ 18,320$ & $\$ 25,027$ \\
\hline & Wholesale prices & $\$ 28,710$ & $\$ 26,664$ & $\$ 28,642$ & $\$ 22,050$ & $\$ 17,663$ & $\$ 23,989$ \\
\hline & Dealer margins & $\$ 1,341$ & $\$ 1,165$ & $\$ 1,247$ & $\$ 995$ & $\$ 657$ & $\$ 1,038$ \\
\hline \multirow[t]{3}{*}{ Toyota } & Retail prices & $\$ \overline{3} 6, \overline{3} 8 \overline{9}$ & $\$ 29,258$ & $\$ 31,845$ & $\$ \overline{2} \overline{8}, 0 \overline{6} \overline{4}$ & $\$ 19,808$ & $\$ 25,888$ \\
\hline & Wholesale prices & $\$ 34,589$ & $\$ 27,870$ & $\$ 30,383$ & $\$ 26,856$ & $\$ 19,037$ & $\$ 24,759$ \\
\hline & Dealer margins & $\$ 1,799$ & $\$ 1,389$ & $\$ 1,462$ & $\$ 1,208$ & $\$ 771$ & $\$ 1,129$ \\
\hline \multirow[t]{3}{*}{$\overline{\mathrm{V}} \overline{\mathrm{W}}^{-}$} & Retail prices & $\$ 5 \overline{2}, \overline{3} 56$ & $\$ 43,228$ & $\$ 33,938$ & $\$ \overline{2} 4,2 \overline{6} 6$ & $\$ 23,815$ & $\$ 27,036$ \\
\hline & Wholesale prices & $\$ 49,493$ & $\$ 41,363$ & $\$ 32,444$ & $\$ 23,141$ & $\$ 23,020$ & $\$ 25,891$ \\
\hline & Dealer margins & $\$ 2,863$ & $\$ 1,865$ & $\$ 1,494$ & $\$ 1,125$ & $\$ 795$ & $\$ 1,145$ \\
\hline \multirow[t]{3}{*}{ Asia } & Retail prices & $\$ 33,149$ & $\$ 28,649$ & $\$ 28,832$ & $\$ 24,274$ & $\$ 18,695$ & $\$ 23,874$ \\
\hline & Wholesale prices & $\$ 31,581$ & $\$ 27,287$ & $\$ 27,477$ & $\$ 23,204$ & $\$ 17,995$ & $\$ 22,838$ \\
\hline & Dealer margins & $\$ 1,567$ & $\$ 1,362$ & $\$ 1,354$ & $\$ 1,070$ & $\$ 701$ & $\$ 1,036$ \\
\hline \multirow[t]{3}{*}{ Europe } & Retail prices & $\$ 65,840$ & $\$ 56,922$ & $\$ 42,489$ & $\$ \overline{2} \overline{8}, \overline{1} \overline{8}$ & $\$ 24,598$ & $\$ 38,455$ \\
\hline & Wholesale prices & $\$ 62,832$ & $\$ 54,536$ & $\$ 40,847$ & $\$ 27,595$ & $\$ 23,524$ & $\$ 36,855$ \\
\hline & Dealer margins & $\$ 3,009$ & $\$ 2,386$ & $\$ 1,642$ & $\$ 1,223$ & $\$ 1,074$ & $\$ 1,600$ \\
\hline \multirow[t]{3}{*}{ U'. } & Retail prices & $\$ \overline{2}, \overline{6} \overline{6}$ & $\$ 26,558$ & $\$ 25,905$ & $\$ \overline{2} \overline{0} \overline{0} \overline{7}$ & $\$ 16,2 \overline{4}$ & $\$ 25,43 \overline{3}$ \\
\hline & Wholesale prices & $\$ 28,445$ & $\$ 25,380$ & $\$ 24,672$ & $\$ 19,542$ & $\$ 15,465$ & $\$ 24,249$ \\
\hline & Dealer margins & $\$ 1,420$ & $\$ 1,178$ & $\$ 1,233$ & $\$ 965$ & $\$ 776$ & $\$ 1,184$ \\
\hline
\end{tabular}

${ }^{\dagger}$ All calculations based on sample averages 
Table A-13: Used Cars: Shares, sales units, retail prices, and retail revenues by MPG bin ${ }^{\dagger}$

\begin{tabular}{|c|c|c|c|c|c|c|c|}
\hline & Variable & MPG Bin 1 & MPG Bin 2 & MPG Bin 3 & MPG Bin 4 & MPG Bin 5 & Total/Average \\
\hline \multirow[t]{4}{*}{ BMW } & Bin Share & $2.6 \%$ & $23 \%$ & $52 \%$ & $16 \%$ & $6.3 \%$ & $100 \%$ \\
\hline & Sales units & 3,877 & 33,814 & 77,140 & 23,162 & 9,266 & 147,260 \\
\hline & Retail prices & $\$ 42,439$ & $\$ 34,500$ & $\$ 27,683$ & $\$ 26,030$ & $\$ 18,881$ & $\$ 28,823$ \\
\hline & Retail revenues & $\$ 165 \mathrm{M}$ & $\$ 1,167 \mathrm{M}$ & $\$ 2,135 \mathrm{M}$ & $\$ 603 \mathrm{M}$ & $\$ 175 \mathrm{M}$ & $\$ 4,244 \mathrm{M}$ \\
\hline \multirow[t]{4}{*}{ Chrysler } & Bin Share & $3 \overline{2} \%$ & $32 \%$ & $17 \%$ & $12 \%$ & $7.7 \%$ & $100 \%$ \\
\hline & Sales units & 593,595 & 602,292 & 312,818 & 230,299 & 144,701 & 1883704 \\
\hline & Retail prices & $\$ 16,135$ & $\$ 15,075$ & $\$ 13,514$ & $\$ 12,014$ & $\$ 9,918$ & $\$ 14,379$ \\
\hline & Retail revenues & $\$ 9,577 \mathrm{M}$ & $\$ 9,080 \mathrm{M}$ & $\$ 4,227 \mathrm{M}$ & $\$ 2,767 \mathrm{M}$ & $\$ 1,435 \mathrm{M}$ & $\$ 27,086 \mathrm{M}$ \\
\hline \multirow[t]{4}{*}{ Ford } & Bin Share & $\overline{3} \overline{\%}$ & $28 \%$ & $20 \%$ & $10 \%$ & $10 \%$ & $100 \%$ \\
\hline & Sales units & 1020030 & 868,511 & 616,499 & 313,246 & 318,207 & 3136492 \\
\hline & Retail prices & $\$ 17,315$ & $\$ 14,774$ & $\$ 12,442$ & $\$ 10,943$ & $\$ 9,012$ & $\$ 14,175$ \\
\hline & Retail revenues & $\$ 17,662 \mathrm{M}$ & $\$ 12,831 \mathrm{M}$ & $\$ 7,671 \mathrm{M}$ & $\$ 3,428 \mathrm{M}$ & $\$ 2,868 \mathrm{M}$ & $\$ 44,460 \mathrm{M}$ \\
\hline \multirow[t]{4}{*}{$\overline{\mathrm{GM}}$} & Bin Share & $22 \%$ & $25 \%$ & $16 \%$ & $25 \%$ & $12 \%$ & $100 \%$ \\
\hline & Sales units & 880,256 & 997,569 & 644,804 & 1014254 & 503,542 & 4040426 \\
\hline & Retail prices & $\$ 19,729$ & $\$ 16,780$ & $\$ 14,994$ & $\$ 11,279$ & $\$ 9,786$ & $\$ 14,885$ \\
\hline & Retail revenues & $\$ 17,366 \mathrm{M}$ & $\$ 16,739 \mathrm{M}$ & $\$ 9,668 \mathrm{M}$ & $\$ 11,440 \mathrm{M}$ & $\$ 4,928 \mathrm{M}$ & $\$ 60,142 \mathrm{M}$ \\
\hline \multirow[t]{4}{*}{ Honda } & Bin Share & $.4 \overline{4} \%$ & $10 \%$ & $13 \%$ & $37 \%$ & $40 \%$ & $100 \%$ \\
\hline & Sales units & 2,315 & 53,658 & 65,915 & 194,174 & 209,275 & 525,337 \\
\hline & Retail prices & $\$ 13,061$ & $\$ 21,798$ & $\$ 18,525$ & $\$ 15,189$ & $\$ 12,829$ & $\$ 15,333$ \\
\hline & Retail revenues & $\$ 30 \mathrm{M}$ & $\$ 1,170 \mathrm{M}$ & $\$ 1,221 \mathrm{M}$ & $\$ 2,949 \mathrm{M}$ & $\$ 2,685 \mathrm{M}$ & $\$ 8,055 \mathrm{M}$ \\
\hline \multirow[t]{4}{*}{ Hyundai } & Bin Share & $\overline{2} \%$ & $18 \%$ & $20 \%$ & $2 \overline{4} \%$ & $36 \%$ & $100 \%$ \\
\hline & Sales units & 4,800 & 41,545 & 47,216 & 55,881 & 84,920 & 234,361 \\
\hline & Retail prices & $\$ 14,577$ & $\$ 13,126$ & $\$ 13,469$ & $\$ 10,487$ & $\$ 9,911$ & $\$ 11,431$ \\
\hline & Retail revenues & $\$ 70 \mathrm{M}$ & $\$ 545 \mathrm{M}$ & $\$ 636 \mathrm{M}$ & $\$ 586 \mathrm{M}$ & $\$ 842 \mathrm{M}$ & $\$ 2,679 \mathrm{M}$ \\
\hline \multirow[t]{4}{*}{ Mazda } & Bin Share & $.8 \%$ & $20 \%$ & $18 \%$ & $35 \%$ & $26 \%$ & $100 \%$ \\
\hline & Sales units & 1,286 & 32,813 & 29,173 & 55,620 & 41,693 & 160,585 \\
\hline & Retail prices & $\$ 12,763$ & $\$ 15,210$ & $\$ 12,687$ & $\$ 12,011$ & $\$ 10,911$ & $\$ 12,508$ \\
\hline & Retail revenues & $\$ 16 \mathrm{M}$ & $\$ 499 \mathrm{M}$ & $\$ 370 \mathrm{M}$ & $\$ 668 \mathrm{M}$ & $\$ 455 \mathrm{M}$ & $\$ 2,009 \mathrm{M}$ \\
\hline \multirow[t]{4}{*}{ Mercedes } & Bin Share & $12 \overline{\%}$ & $38 \%$ & $31 \%$ & $1 \overline{9} \%$ & $.69 \%$ & $100 \%$ \\
\hline & Sales units & 14,561 & 46,879 & 38,090 & 24,318 & 860 & 124,707 \\
\hline & Retail prices & $\$ 39,580$ & $\$ 37,572$ & $\$ 28,606$ & $\$ 25,444$ & $\$ 30,345$ & $\$ 32,653$ \\
\hline & Retail revenues & $\$ 576 \mathrm{M}$ & $\$ 1,761 \mathrm{M}$ & $\$ 1,090 \mathrm{M}$ & $\$ 619 \mathrm{M}$ & $\$ 26 \mathrm{M}$ & $\$ 4,072 \mathrm{M}$ \\
\hline \multirow[t]{4}{*}{ Nissan } & Bin Share & $15 \%$ & $17 \%$ & $22 \%$ & $30 \%$ & $17 \%$ & $100 \%$ \\
\hline & Sales units & 72,805 & 83,836 & 109,703 & 151,364 & 83,738 & 501,447 \\
\hline & Retail prices & $\$ 18,565$ & $\$ 17,908$ & $\$ 17,943$ & $\$ 14,015$ & $\$ 11,881$ & $\$ 15,830$ \\
\hline & Retail revenues & $\$ 1,352 \mathrm{M}$ & $\$ 1,501 \mathrm{M}$ & $\$ 1,968 \mathrm{M}$ & $\$ 2,121 \mathrm{M}$ & $\$ 995 \mathrm{M}$ & $\$ 7,938 \mathrm{M}$ \\
\hline \multirow[t]{4}{*}{ Toyota } & Bin Share & $8 . \overline{3} \%$ & $18 \%$ & $15 \%$ & $2 \overline{4} \%$ & $34 \%$ & $100 \%$ \\
\hline & Sales units & 74,223 & 160,182 & 135,301 & 216,315 & 307,404 & 893,425 \\
\hline & Retail prices & $\$ 24,412$ & $\$ 20,024$ & $\$ 20,607$ & $\$ 16,725$ & $\$ 13,365$ & $\$ 17,387$ \\
\hline & Retail revenues & $\$ 1,812 \mathrm{M}$ & $\$ 3,208 \mathrm{M}$ & $\$ 2,788 \mathrm{M}$ & $\$ 3,618 \mathrm{M}$ & $\$ 4,108 \mathrm{M}$ & $\$ 15,534 \mathrm{M}$ \\
\hline \multirow[t]{4}{*}{$\bar{V} \bar{W}-$} & Bin Share & $1 . \overline{8} \%$ & $9.9 \%$ & $13 \%$ & $\overline{6} \overline{0} \overline{\%}$ & $15 \%$ & $100 \%$ \\
\hline & Sales units & 3,263 & 18,170 & 24,295 & 109,206 & 28,345 & 183,279 \\
\hline & Retail prices & $\$ 31,282$ & $\$ 24,660$ & $\$ 19,235$ & $\$ 14,597$ & $\$ 16,369$ & $\$ 16,780$ \\
\hline & Retail revenues & $\$ 102 \mathrm{M}$ & $\$ 448 \mathrm{M}$ & $\$ 467 \mathrm{M}$ & $\$ 1,594 \mathrm{M}$ & $\$ 464 \mathrm{M}$ & $\$ 3,076 \mathrm{M}$ \\
\hline \multirow[t]{4}{*}{ Asia } & Bin Share & $6.5 \%$ & $16 \%$ & $17 \%$ & $29 \%$ & $32 \%$ & $100 \%$ \\
\hline & Sales units & 151,331 & 365,635 & 385,425 & 682,325 & 730,439 & $2,315,155$ \\
\hline & Retail prices & $\$ 20,943$ & $\$ 18,661$ & $\$ 18,017$ & $\$ 14,757$ & $\$ 12,492$ & $\$ 15,606$ \\
\hline & Retail revenues & $\$ 3,169 \mathrm{M}$ & $\$ 6,823 \mathrm{M}$ & $\$ 6,944 \mathrm{M}$ & $\$ 10,069 \mathrm{M}$ & $\$ 9,125 \mathrm{M}$ & $\$ 36,130 \mathrm{M}$ \\
\hline \multirow[t]{4}{*}{ Europe } & Bin Share & $4.5 \%$ & $21 \%$ & $30 \%$ & $\overline{3} \overline{6} \%$ & $8.9 \%$ & $100 \%$ \\
\hline & Sales units & 20,611 & 95,377 & 136,078 & 162,758 & 40,423 & 455,247 \\
\hline & Retail prices & $\$ 38,684$ & $\$ 33,855$ & $\$ 26,290$ & $\$ 17,661$ & $\$ 17,201$ & $\$ 24,544$ \\
\hline & Retail revenues & $\$ 797 \mathrm{M}$ & $\$ 3,229 \mathrm{M}$ & $\$ 3,577 \mathrm{M}$ & $\$ 2,874 \mathrm{M}$ & $\$ 695 \mathrm{M}$ & $\$ 11,173 \mathrm{M}$ \\
\hline \multirow[t]{4}{*}{ U.'. } & Bin Share & $\overline{2} \overline{8} \%$ & $28 \%$ & $17 \%$ & $\overline{1} \overline{\bar{\gamma}} \overline{\mathrm{c}}$ & $10 \%$ & $100 \%$ \\
\hline & Sales units & 2506090 & 2493822 & 1565284 & 1544556 & 950,870 & $9,060,622$ \\
\hline & Retail prices & $\$ 17,778$ & $\$ 15,636$ & $\$ 13,721$ & $\$ 11,356$ & $\$ 9,579$ & $\$ 14,532$ \\
\hline & Retail revenues & $\$ 44,554 \mathrm{M}$ & $\$ 38,994 \mathrm{M}$ & $\$ 21,477 \mathrm{M}$ & $\$ 17,539 \mathrm{M}$ & $\$ 9,108 \mathrm{M}$ & $\$ 131,673 \mathrm{M}$ \\
\hline
\end{tabular}

${ }^{\dagger}$ All calculations based on sample averages 
Table A-14: Used Cars: Retail prices, wholesale prices, and dealer margins by MPG bin ${ }^{\dagger}$

\begin{tabular}{|c|c|c|c|c|c|c|c|}
\hline & Variable & MPG Bin 1 & MPG Bin 2 & MPG Bin 3 & MPG Bin 4 & MPG Bin 5 & Average \\
\hline \multirow[t]{3}{*}{ BMW } & Retail prices & $\$ 42,439$ & $\$ 34,500$ & $\$ 27,683$ & $\$ 26,030$ & $\$ 18,881$ & $\$ 28,823$ \\
\hline & Wholesale prices & $\$ 39,566$ & $\$ 32,062$ & $\$ 25,551$ & $\$ 23,921$ & $\$ 17,181$ & $\$ 26,632$ \\
\hline & Dealer margins & $\$ 2,873$ & $\$ 2,437$ & $\$ 2,132$ & $\$ 2,109$ & $\$ 1,700$ & $\$ 2,191$ \\
\hline \multirow[t]{3}{*}{ Chrysler } & Retail prices & $\$ 16,135$ & $\$ 15,075$ & $\$ 13,514$ & $\$ 12,014$ & $\$ 9,918$ & $\$ 14,379$ \\
\hline & Wholesale prices & $\$ 14,312$ & $\$ 13,366$ & $\$ 11,812$ & $\$ 10,399$ & $\$ 8,498$ & $\$ 12,669$ \\
\hline & Dealer margins & $\$ 1,823$ & $\$ 1,709$ & $\$ 1,701$ & $\$ 1,615$ & $\$ 1,420$ & $\$ 1,710$ \\
\hline \multirow[t]{3}{*}{ Ford } & Retail prices & $\$ 17,315$ & $\$ 14,774$ & $\$ 12,442$ & $\$ \overline{10}, \overline{4} \overline{3}$ & $\$ 9,012$ & $\$ 14,175$ \\
\hline & Wholesale prices & $\$ 15,538$ & $\$ 13,055$ & $\$ 10,872$ & $\$ 9,469$ & $\$ 7,616$ & $\$ 12,523$ \\
\hline & Dealer margins & $\$ 1,778$ & $\$ 1,719$ & $\$ 1,570$ & $\$ 1,474$ & $\$ 1,396$ & $\$ 1,652$ \\
\hline \multirow[t]{3}{*}{$\mathrm{GM}$} & Retail prices & $\$ \overline{1} \overline{7} \overline{2} \overline{9}$ & $\$ 16,780$ & $\$ 14,994$ & $\$ \overline{1} 1, \overline{2} \overline{9}$ & $\$ 9,786$ & $\$ 14,885$ \\
\hline & Wholesale prices & $\$ 17,869$ & $\$ 14,908$ & $\$ 13,208$ & $\$ 9,657$ & $\$ 8,322$ & $\$ 13,143$ \\
\hline & Dealer margins & $\$ 1,860$ & $\$ 1,872$ & $\$ 1,786$ & $\$ 1,622$ & $\$ 1,465$ & $\$ 1,742$ \\
\hline \multirow{3}{*}{ Honda } & Retail prices & $\$ 13,06 \overline{1}$ & $\$ 21,798$ & $\$ 18,525$ & $\$ 15,189$ & $\$ 12,829$ & $\$ 15,333$ \\
\hline & Wholesale prices & $\$ 11,394$ & $\$ 20,176$ & $\$ 16,886$ & $\$ 13,714$ & $\$ 11,426$ & $\$ 13,851$ \\
\hline & Dealer margins & $\$ 1,667$ & $\$ 1,622$ & $\$ 1,640$ & $\$ 1,475$ & $\$ 1,403$ & $\$ 1,483$ \\
\hline \multirow[t]{3}{*}{ Hyundai } & Retail prices & $\$ 1 \overline{4}, \overline{7} \overline{7}$ & $\$ 13,126$ & $\$ 13,469$ & $\$ \overline{1} \overline{0} \overline{4} \overline{8} \overline{7}$ & $\$ 9,911$ & $\$ 11,431$ \\
\hline & Wholesale prices & $\$ 12,709$ & $\$ 11,346$ & $\$ 11,753$ & $\$ 8,894$ & $\$ 8,493$ & $\$ 9,837$ \\
\hline & Dealer margins & $\$ 1,867$ & $\$ 1,780$ & $\$ 1,716$ & $\$ 1,593$ & $\$ 1,418$ & $\$ 1,593$ \\
\hline \multirow[t]{3}{*}{ Mazda } & Retail prices & $\$ 12, \overline{6} 33$ & $\$ 15,210$ & $\$ 12,687$ & $\$ 12,01 \overline{1}$ & $\$ 10,911$ & $\$ 12,508$ \\
\hline & Wholesale prices & $\$ 11,010$ & $\$ 13,616$ & $\$ 11,156$ & $\$ 10,537$ & $\$ 9,581$ & $\$ 11,034$ \\
\hline & Dealer margins & $\$ 1,753$ & $\$ 1,594$ & $\$ 1,532$ & $\$ 1,474$ & $\$ 1,330$ & $\$ 1,474$ \\
\hline \multirow[t]{3}{*}{ Mercedes } & Retail prices & $\$ 39,580$ & $\$ 37,572$ & $\$ 28,606$ & $\$ 25,4 \overline{4} 4$ & $\$ 30,345$ & $\$ 32,653$ \\
\hline & Wholesale prices & $\$ 36,814$ & $\$ 34,876$ & $\$ 26,333$ & $\$ 23,267$ & $\$ 27,664$ & $\$ 30,179$ \\
\hline & Dealer margins & $\$ 2,766$ & $\$ 2,696$ & $\$ 2,273$ & $\$ 2,177$ & $\$ 2,681$ & $\$ 2,474$ \\
\hline \multirow[t]{3}{*}{ Nissan } & Retail prices & $\$ 18,565$ & $\$ 17,908$ & $\$ 17,943$ & $\$ 14,015$ & $\$ 11,881$ & $\$ 15,830$ \\
\hline & Wholesale prices & $\$ 16,802$ & $\$ 16,287$ & $\$ 16,387$ & $\$ 12,471$ & $\$ 10,542$ & $\$ 14,272$ \\
\hline & Dealer margins & $\$ 1,763$ & $\$ 1,621$ & $\$ 1,556$ & $\$ 1,545$ & $\$ 1,339$ & $\$ 1,557$ \\
\hline \multirow[t]{3}{*}{ Toyota } & Retail prices & $\$ \overline{2}, \overline{4} 12$ & $\$ 20,024$ & $\$ 20,607$ & $\$ 16,725$ & $\$ 13,365$ & $\$ 17,387$ \\
\hline & Wholesale prices & $\$ 22,516$ & $\$ 18,230$ & $\$ 18,781$ & $\$ 15,120$ & $\$ 11,959$ & $\$ 15,759$ \\
\hline & Dealer margins & $\$ 1,896$ & $\$ 1,794$ & $\$ 1,826$ & $\$ 1,604$ & $\$ 1,406$ & $\$ 1,628$ \\
\hline \multirow[t]{3}{*}{$\overline{\mathrm{V}} \overline{\mathrm{W}}^{-}$} & Retail prices & $\$ 3 \overline{1}, \overline{2} 8 \overline{2}$ & $\$ 24,660$ & $\$ 19,235$ & $\$ 14,597$ & $\$ 16,369$ & $\$ 16,780$ \\
\hline & Wholesale prices & $\$ 29,151$ & $\$ 22,642$ & $\$ 17,452$ & $\$ 13,012$ & $\$ 14,844$ & $\$ 15,126$ \\
\hline & Dealer margins & $\$ 2,131$ & $\$ 2,018$ & $\$ 1,783$ & $\$ 1,585$ & $\$ 1,525$ & $\$ 1,654$ \\
\hline \multirow[t]{3}{*}{ Asia } & Retail prices & $\$ 20,943$ & $\$ 18,661$ & $\$ 18,017$ & $\$ 14,757$ & $\$ 12,492$ & $\$ 15,606$ \\
\hline & Wholesale prices & $\$ 19,118$ & $\$ 16,954$ & $\$ 16,339$ & $\$ 13,218$ & $\$ 11,097$ & $\$ 14,044$ \\
\hline & Dealer margins & $\$ 1,825$ & $\$ 1,707$ & $\$ 1,677$ & $\$ 1,538$ & $\$ 1,395$ & $\$ 1,561$ \\
\hline \multirow[t]{3}{*}{ Europe } & Retail prices & $\$ \overline{3} 8, \overline{8} 84$ & $\$ 33,855$ & $\$ 26,290$ & $\$ 1 \overline{1}, \overline{6} \overline{1}$ & $\$ 17,201$ & $\$ 2 \overline{4}, 54 \overline{4}$ \\
\hline & Wholesale prices & $\$ 36,007$ & $\$ 31,388$ & $\$ 24,189$ & $\$ 15,923$ & $\$ 15,614$ & $\$ 22,515$ \\
\hline & Dealer margins & $\$ 2,677$ & $\$ 2,467$ & $\$ 2,101$ & $\$ 1,738$ & $\$ 1,586$ & $\$ 2,028$ \\
\hline \multirow[t]{3}{*}{ U'. } & Retail prices & $\$ \overline{1} \overline{7}, \overline{7} \overline{8}$ & $\$ 15,636$ & $\$ 13,721$ & $\$ \overline{1} \overline{1}, \overline{3} \overline{6}$ & $\$ 9,579$ & $\$ 14,532$ \\
\hline & Wholesale prices & $\$ 15,960$ & $\$ 13,861$ & $\$ 12,033$ & $\$ 9,762$ & $\$ 8,144$ & $\$ 12,827$ \\
\hline & Dealer margins & $\$ 1,819$ & $\$ 1,775$ & $\$ 1,689$ & $\$ 1,594$ & $\$ 1,435$ & $\$ 1,706$ \\
\hline
\end{tabular}

${ }^{\dagger}$ All calculations based on sample averages 
Table A-15: Used Cars: Retail revenue changes implied by $\$ 1$ increase in gasoline prices ${ }^{\dagger}$

\begin{tabular}{|c|c|c|c|c|c|c|c|}
\hline & Implied & MPG Bin 1 & MPG Bin 2 & MPG Bin 3 & MPG $\operatorname{Bin} 4$ & MPG Bin 5 & Total \\
\hline BMW & $\begin{array}{l}\Delta \text { Retail revenues } \\
\% \text { change }\end{array}$ & $\begin{array}{r}\$-20 \mathrm{M} \\
-12 \%\end{array}$ & $\begin{array}{r}\$-109 \mathrm{M} \\
-9.3 \%\end{array}$ & $\begin{array}{r}\$-146 \mathrm{M} \\
-6.8 \%\end{array}$ & $\begin{array}{r}\$ 59 \mathrm{M} \\
9.8 \%\end{array}$ & $\begin{array}{r}\$ 54 \mathrm{M} \\
31 \%\end{array}$ & $\begin{array}{r}\$-162 \mathrm{M} \\
-3.8 \%\end{array}$ \\
\hline Chrysler & $\begin{array}{l}\Delta \text { Retail revenues } \\
\% \text { change }\end{array}$ & $\begin{array}{r}\$-1,772 \mathrm{M} \\
-19 \%\end{array}$ & $\begin{array}{r}\$-384 \mathrm{M} \\
-4.2 \%\end{array}$ & $\begin{array}{r}\$-59 \mathrm{M} \\
-1.4 \%\end{array}$ & $\begin{array}{r}\$ 61 \mathrm{M} \\
2.2 \%\end{array}$ & $\begin{array}{r}\$-46 \mathrm{M} \\
-3.2 \%\end{array}$ & $\begin{array}{r}\$-2,200 \mathrm{M} \\
-8.1 \%\end{array}$ \\
\hline Ford & $\begin{array}{l}\Delta \text { Retail revenues } \\
\% \text { change }\end{array}$ & $\begin{array}{r}\$-3,205 \mathrm{M}^{-} \\
-18 \%\end{array}$ & $\begin{array}{r}\$ 537 \mathrm{M} \\
-4.2 \%\end{array}$ & $\begin{array}{r}\$-82 \mathrm{M} \\
-1.1 \%\end{array}$ & $\begin{array}{r}\$ 98 \bar{M} \\
2.8 \%\end{array}$ & $\begin{array}{r}\$-69 \bar{M} \\
-2.4 \%\end{array}$ & $\begin{array}{r}\$-3,795 \mathrm{M} \\
-8.5 \%\end{array}$ \\
\hline $\mathrm{GM}$ & $\begin{array}{l}\Delta \text { Retail revenues } \\
\% \text { change }\end{array}$ & $\begin{array}{r}\$-3,048 \mathrm{M}^{-} \\
-18 \%\end{array}$ & $\begin{array}{r}-746 \mathrm{M} \\
-4.5 \%\end{array}$ & $\begin{array}{r}-174 \mathrm{M} \\
-1.8 \%\end{array}$ & $\begin{array}{r}\$ 302 \mathrm{M} \\
2.6 \%\end{array}$ & $\begin{array}{r}-151 \mathrm{M} \\
-3.1 \%\end{array}$ & $\begin{array}{r}\$-3,818 \mathrm{M} \\
-6.3 \%\end{array}$ \\
\hline Honda & $\begin{array}{l}\Delta \text { Retail revenues } \\
\% \text { change }\end{array}$ & $\begin{array}{r}\$-7.3 \mathrm{M} \\
-24 \%\end{array}$ & $\begin{array}{r}\$-65 \mathrm{M} \\
-5.5 \%\end{array}$ & $\begin{array}{r}\$-21 \mathrm{M} \\
-1.8 \%\end{array}$ & $\begin{array}{r}\$ 136 \mathrm{M} \\
4.6 \%\end{array}$ & $\begin{array}{r}\$ 448 \mathrm{M} \\
17 \%\end{array}$ & $\begin{array}{r}\$ 490 \mathrm{M} \\
6.1 \%\end{array}$ \\
\hline Hyundai & $\begin{array}{l}\Delta \text { Retail revenues } \\
\% \text { change }\end{array}$ & $\begin{array}{r}\$-16 \bar{M} \\
-23 \%\end{array}$ & $\begin{array}{r}\$-31 \mathrm{M} \\
-5.7 \%\end{array}$ & $\begin{array}{r}\$-7.3 \bar{M} \\
-1.2 \%\end{array}$ & $\begin{array}{r}\$ 4 \overline{\mathrm{M}} \\
7.2 \%\end{array}$ & $\begin{array}{r}\$ 160 \mathrm{M} \\
19 \%\end{array}$ & $\begin{array}{r}\$ 147 \mathrm{M} \\
5.5 \%\end{array}$ \\
\hline Mazda & $\begin{array}{l}\Delta \text { Retail revenues } \\
\% \text { change }\end{array}$ & $\begin{array}{r}-4 M^{\$} \\
-24 \%\end{array}$ & $\begin{array}{r}\$-28 \mathrm{M} \\
-5.6 \%\end{array}$ & $\begin{array}{r}\$-3.8 \mathrm{M} \\
-1 \%\end{array}$ & $\begin{array}{r}\$ 4 \bar{M} \\
6.1 \%\end{array}$ & $\begin{array}{r}\$ 82 \mathrm{M} \\
18 \%\end{array}$ & $\begin{array}{r}\$ 87 \mathrm{M} \\
4.3 \%\end{array}$ \\
\hline Mercedes & $\begin{array}{l}\Delta \text { Retail revenues } \\
\% \text { change }\end{array}$ & $\begin{array}{r}\$-75 \mathrm{M} \\
-13 \%\end{array}$ & $\begin{array}{r}\$-140 \mathrm{M} \\
-8 \%\end{array}$ & $\begin{array}{r}\$-73 \mathrm{M} \\
-6.7 \%\end{array}$ & $\begin{array}{r}\$ 60 \mathrm{M} \\
9.8 \%\end{array}$ & $\begin{array}{r}\$ 7.5 \mathrm{M} \\
29 \%\end{array}$ & $\begin{array}{r}\$-220 \mathrm{M} \\
-5.4 \%\end{array}$ \\
\hline Nissan & $\begin{array}{l}\Delta \text { Retail revenues } \\
\% \text { change }\end{array}$ & $\begin{array}{r}\$-295 \mathrm{M}^{-} \\
-22 \%\end{array}$ & $\begin{array}{r}\$-84 \mathrm{M} \\
-5.6 \%\end{array}$ & $\begin{array}{r}\$-34 \mathrm{M} \\
-1.7 \%\end{array}$ & $\begin{array}{r}\$ 108 \mathrm{M} \\
5.1 \%\end{array}$ & $\begin{array}{r}\$ 172 \mathrm{M} \\
17 \%\end{array}$ & $\begin{array}{r}\$-132 \mathrm{M} \\
-1.7 \%\end{array}$ \\
\hline Toyota & $\begin{array}{l}\Delta \text { Retail revenues } \\
\% \text { change }\end{array}$ & $\begin{array}{r}\$-371 \mathrm{M}^{-} \\
-20 \%\end{array}$ & $\begin{array}{r}\$-178 \mathrm{M} \\
-5.6 \%\end{array}$ & $\begin{array}{r}\$-54 \mathrm{M} \\
-1.9 \%\end{array}$ & $\begin{array}{r}\$ 148 \mathrm{M} \\
4.1 \%\end{array}$ & $\begin{array}{r}\$ 673 \mathrm{M} \\
16 \%\end{array}$ & $\begin{array}{r}\$ 218 \mathrm{M} \\
1.4 \%\end{array}$ \\
\hline$\overline{\mathrm{V}} \overline{\mathrm{W}}$ & $\begin{array}{l}\Delta \text { Retail revenues } \\
\% \text { change }\end{array}$ & $\begin{array}{r}\$-17 \mathrm{M} \\
-17 \% \\
\end{array}$ & $\begin{array}{r}\$-72 \mathrm{M} \\
-16 \% \\
\end{array}$ & $\begin{array}{r}\$-41 \mathrm{M} \\
-8.7 \% \\
\end{array}$ & $\begin{array}{r}\$ 153 \mathrm{M} \\
9.6 \% \\
\end{array}$ & $\begin{array}{r}\$ 145 \mathrm{M} \\
31 \% \\
\end{array}$ & $\begin{array}{r}\$ 169 \mathrm{M} \\
5.5 \% \\
\end{array}$ \\
\hline Asia & $\begin{array}{l}\Delta \text { retail revenues } \\
\% \text { change }\end{array}$ & $\begin{array}{r}\$-672 \mathrm{M} \\
-21 \%\end{array}$ & $\begin{array}{r}\$-381 \mathrm{M} \\
-5.6 \%\end{array}$ & $\begin{array}{r}-119 \mathrm{M} \\
-1.7 \%\end{array}$ & $\begin{array}{r}481 \mathrm{M} \\
4.8 \%\end{array}$ & $\begin{array}{r}\$ 1,542 \mathrm{M} \\
17 \%\end{array}$ & $\begin{array}{r}852 \mathrm{M} \\
2.4 \%\end{array}$ \\
\hline Europe & $\begin{array}{l}\Delta \text { Retail revenues } \\
\% \text { change }\end{array}$ & $\begin{array}{r}\$-106 \mathrm{M}^{-} \\
-13 \%\end{array}$ & $\begin{array}{r}\$-312 \mathrm{M} \\
-9.7 \%\end{array}$ & $\begin{array}{r}-253 \mathrm{M} \\
-7.1 \%\end{array}$ & $\begin{array}{r}\$ 278 \mathrm{M} \\
9.7 \%\end{array}$ & $\begin{array}{r}\$ 216 \mathrm{M} \\
31 \%\end{array}$ & $\begin{array}{r}\$-177 \mathrm{M} \\
-1.6 \%\end{array}$ \\
\hline U.S. & $\begin{array}{l}\Delta \text { Retail revenues } \\
\% \text { change }\end{array}$ & $\begin{array}{r}\$-8,029 \bar{M}^{-} \\
-18 \%\end{array}$ & $\begin{array}{r}\$-1,681 \mathrm{M} \\
-4.3 \%\end{array}$ & $\begin{array}{r}\$-315 \bar{M} \\
-1.5 \%\end{array}$ & $\begin{array}{r}\$ 454 \mathrm{M} \\
2.6 \%\end{array}$ & $\begin{array}{r}\$-264 \mathrm{M} \\
-2.9 \%\end{array}$ & $\begin{array}{r}\$-9,836 \mathrm{M} \\
-7.5 \%\end{array}$ \\
\hline
\end{tabular}

${ }^{\dagger}$ All calculations based on sample averages 
Table A-16: Used Cars: Equilibrium sales response to gasoline prices by origin

\begin{tabular}{|c|c|c|c|c|c|c|c|c|c|}
\hline \multirow[b]{2}{*}{ Variable } & \multicolumn{3}{|c|}{ Asia } & \multicolumn{3}{|c|}{ Europe } & \multicolumn{3}{|c|}{ U.S. } \\
\hline & Coef & Av. Sales & Effect & Coef & Av. Sales & Effect & Coef & Av. Sales & Effect \\
\hline $\begin{array}{l}\text { GasPrice*MPG Bin 1 } \\
\text { (fuel economy }<16 \mathrm{MPG} \text { ) }\end{array}$ & $\begin{array}{c}-317^{* *} \\
(71)\end{array}$ & 1957 & $-16 \%$ & $\begin{array}{c}4.9 \\
(15)\end{array}$ & 260 & $2 \%$ & $\begin{array}{c}-3192^{* *} \\
(485)\end{array}$ & 23952 & $-13 \%$ \\
\hline $\begin{array}{l}\text { GasPrice* MPG } \mathbf{B i n} \mathbf{2} \\
(16 \mathrm{MPG} \leq \mathrm{FE}<19 \mathrm{MPG})\end{array}$ & $\begin{array}{l}-223 \\
(191)\end{array}$ & 4198 & $-5 \%$ & $\begin{array}{c}91 \\
(160)\end{array}$ & 1224 & $7 \%$ & $\begin{array}{c}-1482^{* *} \\
(502)\end{array}$ & 23066 & $-6 \%$ \\
\hline $\begin{array}{l}\text { GasPrice* MPG Bin 3 } \\
(19 \mathrm{MPG} \leq \mathrm{FE}<21 \mathrm{MPG})\end{array}$ & $(169)$ & 4463 & $-3 \%$ & $(55)$ & 1537 & $-3 \%$ & $\begin{array}{l}-960^{*} \\
(479)\end{array}$ & 17805 & $-5 \%$ \\
\hline $\begin{array}{l}\text { GasPrice* MPG Bin } \\
(21 \mathrm{MPG} \leq \mathrm{FE}<24 \mathrm{MPG})\end{array}$ & $\begin{array}{l}-96 \\
(625)\end{array}$ & 8714 & $-1 \%$ & $\begin{array}{l}196+ \\
(115)\end{array}$ & 1949 & $10 \%$ & $\begin{array}{l}-880 \\
(726)\end{array}$ & $20344^{-}$ & $-4 \%$ \\
\hline $\begin{array}{l}\text { GasPrice* MPG Bin 5 } \\
\text { (fuel economy } \geq 24 \mathrm{MPG} \text { ) }\end{array}$ & $(731)$ & 7870 & $9 \%$ & $\begin{array}{l}77^{*} \bar{*}^{-} \\
(15)\end{array}$ & 296 & $26 \%$ & $\begin{array}{c}-1183^{*} \\
(528)\end{array}$ & 10994 & $-11 \%$ \\
\hline
\end{tabular}

* significant at 5\%; ** significant at $1 \%$; significant at $10 \%$ level. Standard errors in parentheses are robust and clustered at the region level.

This table only reports the coefficients on gasoline prices. Full results are available upon request from the authors.

Table A-17: Used cars: Equilibrium price response to gasoline prices by origin

\begin{tabular}{|c|c|c|c|}
\hline Variable & $\begin{array}{c}\text { Asia } \\
\text { Coefficient (SE) }\end{array}$ & $\begin{array}{c}\text { Europe } \\
\text { Coefficient (SE) }\end{array}$ & $\begin{array}{c}\text { U.S. } \\
\text { Coefficient (SE) }\end{array}$ \\
\hline $\begin{array}{l}\text { GasolinePrice*MPG Bin } \mathbf{1}^{\dagger} \\
\text { (fuel economy }<16 \mathrm{MPG} \text { ) }\end{array}$ & $\begin{array}{c}-1247^{* *} \\
(86)\end{array}$ & $\begin{array}{c}-5770^{* *} \\
(202)\end{array}$ & $\begin{array}{c}-968^{* *} \\
(41)\end{array}$ \\
\hline $\begin{array}{l}\text { GasolinePrice* } \mathbf{M} \mathbf{P} \mathbf{G} \text { Bin } \mathbf{2} \\
(16 \mathrm{MPG} \leq \text { fuel economy }<19 \mathrm{MPG})\end{array}$ & $\begin{array}{l}-56 \\
(62)\end{array}$ & $\begin{array}{c}-5396^{* *}- \\
(172)\end{array}$ & $\begin{array}{c}354^{* *} \\
(43)\end{array}$ \\
\hline $\begin{array}{l}\text { GasolinePrice* } \mathbf{M} \mathbf{P} \mathbf{G} \text { Bin } 3 \\
(19 \mathrm{MPG} \leq \text { fuel economy }<21 \mathrm{MPG})\end{array}$ & $\begin{array}{c}309^{* *} \\
(57)\end{array}$ & $\begin{array}{c}-1210^{* *} \\
(76)\end{array}$ & $\begin{array}{c}569^{* *} \\
(45)\end{array}$ \\
\hline $\begin{array}{l}\text { GasolinePrice* } \mathbf{M} \mathbf{P} \mathbf{G} \text { Bin } \mathbf{4} \\
(21 \mathrm{MPG} \leq \text { fuel economy }<24 \mathrm{MPG})\end{array}$ & $\begin{array}{c}877^{*} * \\
(48)\end{array}$ & $(53)$ & $\begin{array}{c}820 * * \\
(47)\end{array}$ \\
\hline $\begin{array}{l}\text { GasolinePrice* } \mathbf{M} \mathbf{P} \text { Bin } \\
\text { (fuel economy } \geq 24 \mathrm{MPG} \text { ) }\end{array}$ & $\begin{array}{c}909^{* *}- \\
(35)\end{array}$ & $\begin{array}{c}706^{* *}- \\
(66)\end{array}$ & $\begin{array}{c}848^{* *}- \\
(44)\end{array}$ \\
\hline Price difference between highest and lowest MPG Bin: & $\$ 2156$ & $\$ 6476$ & $\$ 1816$ \\
\hline
\end{tabular}

* significant at $5 \%$; ${ }^{* *}$ significant at $1 \% ;+$ significant at $10 \%$ level. Standard errors in parentheses are robust and clustered at the region level.

This table only reports the coefficients on gasoline prices. Full results are available upon request from the authors. 
Table A-18: Used cars: Equilibrium wholesaleprice response to gasoline prices by origin

\begin{tabular}{|c|c|c|c|}
\hline Variable & $\begin{array}{c}\text { Asia } \\
\text { Coefficient (SE) }\end{array}$ & $\begin{array}{c}\text { Europe } \\
\text { Coefficient (SE) }\end{array}$ & $\begin{array}{c}\text { U.S. } \\
\text { Coefficient (SE) }\end{array}$ \\
\hline 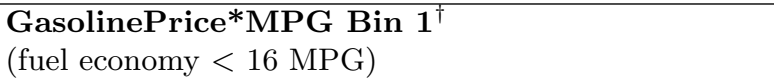 & $\begin{array}{c}-1259^{* *} \\
(88)\end{array}$ & $\begin{array}{c}-5421^{* *} \\
(204)\end{array}$ & $\begin{array}{c}-974^{* *} \\
(40)\end{array}$ \\
\hline $\begin{array}{l}\text { GasolinePrice* MPG Bin } 2 \\
(16 \mathrm{MPG} \leq \text { fuel economy }<19 \mathrm{MPG})\end{array}$ & $\begin{array}{l}-92 \\
(59)\end{array}$ & $\begin{array}{c}-5229^{* *} \\
(170)\end{array}$ & $\begin{array}{c}370^{* *} \\
(41)\end{array}$ \\
\hline $\begin{array}{l}\text { GasolinePrice* MPG Bin } \\
(19 \mathrm{MPG} \leq \text { fuel economy }<21 \mathrm{MPG})\end{array}$ & $\begin{array}{c}256^{* *} \\
(57)\end{array}$ & $\begin{array}{c}-1223^{* *}- \\
(72)\end{array}$ & $\begin{array}{l}618^{* *}- \\
(44)\end{array}$ \\
\hline $\begin{array}{l}\text { GasolinePrice* MPG Bin } \\
(21 \mathrm{MPG} \leq \text { fuel economy }<24 \mathrm{MPG})\end{array}$ & $\begin{array}{l}782^{* * *} \\
(47)\end{array}$ & $\begin{array}{r}-92+ \\
(52)\end{array}$ & $\begin{array}{c}896^{* *} \\
(46)\end{array}$ \\
\hline $\begin{array}{l}\text { GasolinePrice* } \mathbf{M} \mathbf{P} \mathbf{G} \text { Bin } \mathbf{5} \\
\text { (fuel economy } \geq 24 \mathrm{MPG} \text { ) }\end{array}$ & $\begin{array}{l}773^{*} * \\
(37)\end{array}$ & $\begin{array}{c}541^{* * *} \\
(57)\end{array}$ & $\begin{array}{c}915^{* *} \\
(39)\end{array}$ \\
\hline Price difference between highest and lowest MPG Bin: & $\$ 2032$ & $\$ 5962$ & $\$ 1889$ \\
\hline
\end{tabular}

${ }^{*}$ significant at $5 \% ;{ }^{* *}$ significant at $1 \% ;+$ significant at $10 \%$ level. Standard errors in parentheses are robust and clustered at the region level.

This table only reports the coefficients on gasoline prices. Full results are available upon request from the authors.

Table A-19: Used cars: Equilibrium dealer margin response to gasoline prices by origin

\begin{tabular}{|c|c|c|c|}
\hline Variable & $\begin{array}{c}\text { Asia } \\
\text { Coefficient (SE) }\end{array}$ & $\begin{array}{c}\text { Europe } \\
\text { Coefficient (SE) }\end{array}$ & $\begin{array}{c}\text { U.S. } \\
\text { Coefficient (SE) }\end{array}$ \\
\hline $\begin{array}{l}\text { GasolinePrice*MPG Bin } \mathbf{1}^{\dagger} \\
\text { (fuel economy }<16 \mathrm{MPG} \text { ) }\end{array}$ & $\begin{array}{c}13 \\
(23)\end{array}$ & $\begin{array}{c}-350^{* *} \\
(56)\end{array}$ & $\begin{array}{c}5.9 \\
(11)\end{array}$ \\
\hline $\begin{array}{l}\text { GasolinePrice*MPG Bin } \mathbf{2} \\
(16 \mathrm{MPG} \leq \text { fuel economy }<19 \mathrm{MPG})\end{array}$ & $\begin{array}{l}36+ \\
(19)\end{array}$ & $\begin{array}{c}-167^{*} * \\
(22)\end{array}$ & $\begin{array}{l}-16 \\
(10)\end{array}$ \\
\hline $\begin{array}{l}\text { GasolinePrice* MPG Bin 3 } \\
(19 \mathrm{MPG} \leq \text { fuel economy }<21 \mathrm{MPG})\end{array}$ & $53^{*} *$ & $\begin{array}{l}13 \\
(27)\end{array}$ & $\begin{array}{c}-49^{* *}- \\
(12)\end{array}$ \\
\hline $\begin{array}{l}\text { GasolinePrice* MPG Bin 4 } \\
(21 \mathrm{MPG} \leq \text { fuel economy }<24 \mathrm{MPG})\end{array}$ & $\begin{array}{l}95^{*} * \\
(12)\end{array}$ & $(15)$ & $\begin{array}{c}-76^{* * *} \\
(13)\end{array}$ \\
\hline $\begin{array}{l}\text { GasolinePrice* MPG Bin 5 } \\
\text { (fuel economy } \geq 24 \mathrm{MPG} \text { ) }\end{array}$ & $\begin{array}{c}136^{* *} \\
(12)\end{array}$ & $\begin{array}{l}164^{* *} \\
(27)\end{array}$ & $(14)$ \\
\hline Price difference between highest and lowest MPG Bin: & $\$ 123$ & $\$ 514$ & $-\$ 73$ \\
\hline
\end{tabular}

${ }^{*}$ significant at $5 \% ;{ }^{* *}$ significant at $1 \% ;+$ significant at $10 \%$ level. Standard errors in parentheses are robust and clustered at the region level.

This table only reports the coefficients on gasoline prices. Full results are available upon request from the authors. 
Table A-20: Heterogeneity by gasoline price levels: Equilibrium prices

\begin{tabular}{|c|c|c|c|c|c|c|}
\hline \multirow[b]{2}{*}{ Variables } & \multicolumn{3}{|c|}{$\begin{array}{c}\text { New Vehicles } \\
\text { Gasoline Price Range }\end{array}$} & \multicolumn{3}{|c|}{$\begin{array}{c}\text { Used Vehicles } \\
\text { Gasoline Price Range }\end{array}$} \\
\hline & $<\$ 2$ & $\$ 2$ to $\$ 3$ & $\geq \$ 3$ & $<\$ 2$ & $\$ 2$ to $\$ 3$ & $\geq \$ 3$ \\
\hline $\begin{array}{l}\text { GasolinePrice*MPG Bin } 1 \\
\text { (fuel economy }<16 \mathrm{MPG} \text { ) }\end{array}$ & $\begin{array}{l}-109 \\
(98)\end{array}$ & $\begin{array}{c}-275^{* *} \\
(99)\end{array}$ & $\begin{array}{c}-300^{* *} \\
(93)\end{array}$ & $\begin{array}{c}-1204^{* *} \\
(61)\end{array}$ & $\begin{array}{c}-1339 * * \\
(49)\end{array}$ & $\begin{array}{c}-1347^{* *} \\
(43)\end{array}$ \\
\hline $\begin{array}{l}(16 \mathrm{MPG} \leq \text { fuel economy }<19 \mathrm{MPG})\end{array}$ & $\begin{array}{c}-181^{* *} \\
(29)\end{array}$ & $\begin{array}{c}-189^{* *} \\
(28)\end{array}$ & $\begin{array}{c}-169^{* *} \\
(29)\end{array}$ & $\begin{array}{c}-298^{* *} \\
(44)\end{array}$ & $\begin{array}{c}-285^{* *--} \\
(51)\end{array}$ & $\begin{array}{c}-321^{* *} \\
(43)\end{array}$ \\
\hline $\begin{array}{l}(19 \mathrm{MPG} \leq \text { fuel economy }<21 \mathrm{MPG})\end{array}$ & $\begin{array}{l}-24 \\
(32)\end{array}$ & $(34)$ & $(33)$ & $\begin{array}{c}311^{* *} \\
(30)\end{array}$ & $\begin{array}{c}403^{* *} \\
(27)\end{array}$ & $\begin{array}{c}330^{* *-} \\
(22)\end{array}$ \\
\hline $\begin{array}{l}(21 \mathrm{MPG} \leq \text { fuel economy }<24 \mathrm{MPG})\end{array}$ & $(40)$ & $\begin{array}{l}116^{*} \\
(45)\end{array}$ & $\begin{array}{c}122^{* *} \\
(40)\end{array}$ & $\begin{array}{c}484^{* \bar{*}} \\
(35)\end{array}$ & $\begin{array}{c}714^{* *}- \\
(27)\end{array}$ & $\begin{array}{c}677^{* *-}-x^{-} \\
(25)\end{array}$ \\
\hline $\begin{array}{l}\text { GasolinePrice } 2 \text { PG } \\
\text { (fuel economy } \geq 24 \mathrm{MPG} \text { ) }\end{array}$ & $\begin{array}{c}257^{*} *^{-} \\
(37)\end{array}$ & $\begin{array}{c}303^{* *} \\
(32)\end{array}$ & $\begin{array}{c}292^{* *} \\
(30)\end{array}$ & $\begin{array}{c}649^{* *} \\
(38)\end{array}$ & $\begin{array}{c}918^{* *} \\
(26)\end{array}$ & $\begin{array}{c}856^{* *}- \\
(24)\end{array}$ \\
\hline Relative price difference $\mathrm{b} / \mathrm{w}$ MPG bin 5 and 1 : & $\$ 366$ & $\$ 578$ & $\$ 592$ & $\$ 1,853$ & $\$ 2,257$ & $\$ 2,203$ \\
\hline
\end{tabular}

* significant at $5 \%$;* significant at $1 \%$; significant at $10 \%$ level. Standard errors in parentheses are robust and clustered at the region level.

This table only reports the coefficients on gasoline prices. Full results are available upon request from the authors.

Table A-21: Heterogeneity by gasoline price levels: Equilibrium shares

\begin{tabular}{|c|c|c|c|c|c|c|}
\hline \multirow[b]{2}{*}{ Variables } & \multicolumn{3}{|c|}{$\begin{array}{c}\text { New Vehicles } \\
\text { Gasoline Price Range }\end{array}$} & \multicolumn{3}{|c|}{$\begin{array}{c}\text { Used Vehicles } \\
\text { Gasoline Price Range }\end{array}$} \\
\hline & $<\$ 2$ & $\$ 2$ to $\$ 3$ & $\geq \$ 3$ & $<\$ 2$ & $\$ 2$ to $\$ 3$ & $\geq \$ 3$ \\
\hline $\begin{array}{l}\text { GasolinePrice*MPG Bin } 1 \\
\text { (fuel economy }<16 \mathrm{MPG} \text { ) }\end{array}$ & $\begin{array}{l}-.046^{* *} \\
(.0048)\end{array}$ & $\begin{array}{r}-.043^{* *} \\
(.0044)\end{array}$ & $\begin{array}{l}-.042^{* *} \\
(.0041)\end{array}$ & $\begin{array}{c}-.0082^{* *} \\
(.0019)\end{array}$ & $\begin{array}{c}-.0081^{* *} \\
(.0017)\end{array}$ & $\begin{array}{c}-.0091^{* *} \\
(.0015)\end{array}$ \\
\hline $\begin{array}{l}\text { GasolinePrice* } 16 \mathrm{MPG} \leq \text { fuel economy }<19 \mathrm{MPG})\end{array}$ & $(.0032)$ & $(.0033)$ & $\begin{array}{c}-.027^{*} *-1 \\
(.003)\end{array}$ & $(.0015)$ & $(.0013)$ & $\begin{array}{l}.0018 \\
(.0012)\end{array}$ \\
\hline $\begin{array}{l}\text { GasolinePrice* MPG Bin } 3 \\
(19 \mathrm{MPG} \leq \text { fuel economy }<21 \mathrm{MPG})\end{array}$ & $\begin{array}{l}.00091 \\
(.002)\end{array}$ & $\begin{array}{l}-.0024 \\
(.0018)\end{array}$ & $(.0016)$ & $\begin{array}{l}.0027 \\
(.0022)\end{array}$ & $(.00056)$ & $\begin{array}{c}-.000093 \\
(.0016)\end{array}$ \\
\hline $\begin{array}{l}\text { GasolinePrice } \mathrm{MPG} \text { Bin } 4 \\
\text { MPG } \leq \text { fuel economy }<24 \mathrm{MPG})\end{array}$ & $\begin{array}{l}.013^{* * *} \\
(.003)\end{array}$ & $(.0027)$ & $(.0028)$ & $\begin{array}{l}.0036^{*} \\
(.0016)\end{array}$ & $\left(.0034^{*}\right.$ & $\begin{array}{l}.0039^{* *} \\
(.0012)\end{array}$ \\
\hline $\begin{array}{l}\text { GasolinePrice } \mathrm{MPG} \text { Bin } 5 \\
\text { (fuel economy } \geq 24 \mathrm{MPG} \text { ) }\end{array}$ & $\begin{array}{l}.053^{* *} \\
(.0031)\end{array}$ & $\begin{array}{l}.052^{*} \bar{x}^{-} \\
(.0029)\end{array}$ & $\begin{array}{l}.057^{*} \bar{x}^{-} \\
(.0028)\end{array}$ & $\begin{array}{l}.0024^{*} \\
(.0012)\end{array}$ & $\begin{array}{l}.0028^{*}{ }^{\prime} \\
(.00094)\end{array}$ & $\begin{array}{l}.0034^{* *} \\
(.00092)\end{array}$ \\
\hline
\end{tabular}

${ }^{*}$ significant at $5 \%$;* significant at $1 \%$; significant at $10 \%$ level. Standard errors in parentheses are robust and clustered at the region level.

This table only reports the coefficients on gasoline prices. Full results are available upon request from the authors. 
Table A-22: Heterogeneity by gasoline price trends: Equilibrium prices

\begin{tabular}{|c|c|c|c|c|c|c|}
\hline \multirow[b]{2}{*}{ Variables } & \multicolumn{3}{|c|}{$\begin{array}{c}\text { New Vehicles } \\
\text { Gasoline Price Trend }\end{array}$} & \multicolumn{3}{|c|}{$\begin{array}{c}\text { Used Vehicles } \\
\text { Gasoline Price Trend }\end{array}$} \\
\hline & Up 10 c & Hold & Down $10 \notin$ & Up 10c & Hold & Down $10 c$ \\
\hline $\begin{array}{l}\text { GasolinePrice*MPG Bin } 1 \\
\text { (fuel economy }<16 \mathrm{MPG} \text { ) }\end{array}$ & $\begin{array}{c}-360^{* *} \\
(89)\end{array}$ & $\begin{array}{c}-244^{*} \\
(90)\end{array}$ & $\begin{array}{c}-350^{* *} \\
(90)\end{array}$ & $\begin{array}{c}-1437^{* *} \\
(39)\end{array}$ & $\begin{array}{c}-1287^{* *} \\
(34)\end{array}$ & $\begin{array}{c}-1481^{* * *} \\
(42)\end{array}$ \\
\hline $\begin{array}{l}\text { GasolinePrice* } \mathrm{MP} G \text { Bin } 2 \\
(16 \mathrm{MPG} \leq \text { fuel economy }<19 \mathrm{MPG})\end{array}$ & $\begin{array}{c}-161 * * \\
(31)\end{array}$ & $\begin{array}{c}-93^{* *}- \\
(33)\end{array}$ & $\begin{array}{l}-177^{*} *{ }^{\prime} \\
(31)\end{array}$ & $\begin{array}{c}-336 * *- \\
(48)\end{array}$ & $(52)$ & $\begin{array}{l}-339^{*} \bar{*}- \\
(50)\end{array}$ \\
\hline $\begin{array}{l}\text { GasolinePrice* } \mathrm{MPG} \text { Bin } 3 \\
(19 \mathrm{MPG} \leq \text { fuel economy }<21 \mathrm{MPG})\end{array}$ & $\begin{array}{l}-17 \\
(33)\end{array}$ & $(35)$ & $\begin{array}{l}-5.3 \\
(35)\end{array}$ & $\begin{array}{c}325^{* *} \\
(22)\end{array}$ & $\begin{array}{c}243^{* *} \\
(23)\end{array}$ & $\begin{array}{c}346^{* * *} \\
(23)\end{array}$ \\
\hline $\begin{array}{l}\text { GasolinePrice* } \mathrm{MPG} \text { Bin } 4 \\
(21 \mathrm{MPG}<\text { fuel economy }<24 \mathrm{MPG})\end{array}$ & $\begin{array}{c}140^{*} x^{-} \\
(36)\end{array}$ & $\begin{array}{c}192^{* *} \\
(43)\end{array}$ & $\begin{array}{c}146^{* *} \\
(37)\end{array}$ & $\begin{array}{c}754^{*} *-- \\
(24)\end{array}$ & $\begin{array}{l}665^{*} \times-1 \\
(22)\end{array}$ & $\begin{array}{l}822^{* *--} \\
(26)\end{array}$ \\
\hline $\begin{array}{l}\text { GasolinePrice } \mathrm{MPG} \text { Bin } 5 \\
\text { (fuel economy } \geq 24 \mathrm{MPG} \text { ) }\end{array}$ & $\begin{array}{l}302^{* *}{ }^{*} \\
(33)\end{array}$ & $\begin{array}{c}334^{* *} \\
(33)\end{array}$ & $(36)$ & $\begin{array}{l}932^{* * *-} \\
(25)\end{array}$ & $\begin{array}{l}860^{*} \bar{*}^{-} \\
(29)\end{array}$ & $\begin{array}{l}1040^{*} *{ }^{2} \\
(26)\end{array}$ \\
\hline Relative price difference $\mathrm{b} / \mathrm{w}$ MPG bin 3 and 1 : & $\$ 662$ & $\$ 578$ & $\$ 670$ & $\$ 2,369$ & $\$ 2,147$ & $\$ 2,521$ \\
\hline
\end{tabular}

* significant at $5 \%$;* significant at $1 \%$; significant at $10 \%$ level. Standard errors in parentheses are robust and clustered at the region level.

This table only reports the coefficients on gasoline prices. Full results are available upon request from the authors.

Table A-23: Heterogeneity by gasoline price trends: Equilibrium shares

\begin{tabular}{|c|c|c|c|c|c|c|}
\hline \multirow[b]{2}{*}{ Variables } & \multicolumn{3}{|c|}{$\begin{array}{c}\text { New Vehicles } \\
\text { Gasoline Price Range }\end{array}$} & \multicolumn{3}{|c|}{$\begin{array}{c}\text { Used Vehicles } \\
\text { Gasoline Price Range }\end{array}$} \\
\hline & Up 10 c & Hold & Down $10 \mathrm{c}$ & Up 10c & Hold & Down $10 c$ \\
\hline $\begin{array}{l}\text { GasolinePrice*MPG Bin } 1 \\
\text { (fuel economy }<16 \mathrm{MPG} \text { ) }\end{array}$ & $\begin{array}{l}-.042^{* *} \\
(.0039)\end{array}$ & $\begin{array}{l}-.046^{* *} \\
(.0045)\end{array}$ & $\begin{array}{l}-.043^{* *} \\
(.0038)\end{array}$ & $\begin{array}{c}-.0092^{* *} \\
(.0015)\end{array}$ & $\begin{array}{c}-.0082^{* *} \\
(.0017)\end{array}$ & $\begin{array}{c}-.0082^{* *} \\
(.0014)\end{array}$ \\
\hline $\begin{array}{l}\text { GasolinePrice } 16 \mathrm{MPG} \leq \text { fuel economy }<19 \mathrm{MPG})\end{array}$ & $\begin{array}{l}-.028^{* * *} \\
(.0028)\end{array}$ & $\begin{array}{l}-.027^{*} \bar{*} \\
(.0033)\end{array}$ & $(.0028)$ & $\begin{array}{l}.0019 \\
(.0012)\end{array}$ & $(.0015)$ & $\begin{array}{l}.0013 \\
(.0013)\end{array}$ \\
\hline $\begin{array}{l}\text { GasolinePrice } \mathrm{MPG} \text { Bin } 3 \\
(19 \mathrm{MPG} \leq \text { fuel economy }<21 \mathrm{MPG})\end{array}$ & $(.0017)$ & $\begin{array}{l}.0011 \\
(.0019)\end{array}$ & $\begin{array}{l}-.0025 \\
(.0019)\end{array}$ & $(.0015)$ & $(.0019)$ & $\begin{array}{l}-.00029 \\
(.0016)\end{array}$ \\
\hline $\begin{array}{l}\text { GasolinePrice* } \mathrm{MPG} \text { Bin } 4 \\
(21 \mathrm{MPG} \leq \text { fuel economy }<24 \mathrm{MPG})\end{array}$ & $\begin{array}{l}.015^{* *} \\
(.003)\end{array}$ & $\begin{array}{l}.013^{* *} \\
(.003)\end{array}$ & $\begin{array}{l}.016 \bar{*}^{*}- \\
(.0031)\end{array}$ & $\begin{array}{l}.0042^{*} *- \\
(.0011)\end{array}$ & $\begin{array}{l}.005^{* *} \\
(.0015)\end{array}$ & $\begin{array}{l}.0038 * *- \\
(.0012)\end{array}$ \\
\hline $\begin{array}{l}\text { GasolinePrice* } \mathrm{MPG} \text { Bin } 5 \\
\text { (fuel economy } \geq 24 \mathrm{MPG} \text { ) }\end{array}$ & $\begin{array}{l}.059 * * \\
(.0029)\end{array}$ & $(.0034)$ & $\begin{array}{l}.056^{* *} \\
(.0029)\end{array}$ & $\begin{array}{l}.0037^{*} \bar{*}^{-} \\
(.00093)\end{array}$ & $\begin{array}{l}.0031^{*} * \\
(.00083)\end{array}$ & $\begin{array}{l}.0033^{* *} \\
(.00094)\end{array}$ \\
\hline
\end{tabular}

${ }^{*}$ significant at $5 \% ;{ }^{* *}$ significant at $1 \%$; significant at $10 \%$ level. Standard errors in parentheses are robust and clustered at the region level.

This table only reports the coefficients on gasoline prices. Full results are available upon request from the authors. 
Table A-24: Examples of cars in segments and subsegments

\begin{tabular}{|c|c|c|c|c|}
\hline Segment & Avg. MPG & Subsegment & Avg. MPG & Example \\
\hline Compact Car & 26.9 & $\begin{array}{l}\text { Entry Compact Car } \\
\text { Premium Compact Car }\end{array}$ & $\begin{array}{l}27.7 \\
26.8\end{array}$ & $\begin{array}{l}\text { Hyundai Accent, Toyota Yaris } \\
\text { Honda Civic, Ford Focus }\end{array}$ \\
\hline Midsize Car & 22.3 & $\begin{array}{l}\text { Entry Midsize Car } \\
\text { Premium Midsize Car }\end{array}$ & $\begin{array}{l}22.4 \\
22.2\end{array}$ & $\begin{array}{l}\text { Pontiac G6, VW Jetta } \\
\text { Honda Accord, Ford Fusion, Nissan Altima }\end{array}$ \\
\hline Luxury Car & 19.6 & $\begin{array}{l}\text { Entry Luxury Car } \\
\text { Mid Luxury Car } \\
\text { Premium Luxury Car } \\
\text { Luxury Sports Car }\end{array}$ & $\begin{array}{l}20.1 \\
19.1 \\
18.0 \\
17.0\end{array}$ & $\begin{array}{l}\text { BMW 3-Series, Acura TSX } \\
\text { BMW 5-Series, Volvo V70 } \\
\text { BMW } 7 \text { Series, Lexus LS Series } \\
\text { BMW } 6 \text { Series, Mercedes SL-Class }\end{array}$ \\
\hline Sporty Car & 20.4 & $\begin{array}{l}\text { Sporty Car } \\
\text { Premium Sports Car }\end{array}$ & $\begin{array}{l}20.8 \\
19.1\end{array}$ & $\begin{array}{l}\text { VW Golf GTI, Ford Mustang } \\
\text { Chevrolet Corvette, Porsche } 911\end{array}$ \\
\hline SUV & 17.0 & $\begin{array}{l}\text { Entry SUV } \\
\text { Midsize SUV } \\
\text { Fullsize SUV } \\
\text { Luxury SUV }\end{array}$ & $\begin{array}{l}19.4 \\
16.4 \\
14.0 \\
16.1\end{array}$ & $\begin{array}{l}\text { Honda CRV, Ford Escape } \\
\text { Toyota 4Runner, Dodge Durango } \\
\text { GMC Yukon, Toyota Sequoia } \\
\text { Acura MDX, Cadillac Escalade }\end{array}$ \\
\hline Pickup & 15.5 & $\begin{array}{l}\text { Compact Pickup } \\
\text { Fullsize Pickup }\end{array}$ & $\begin{array}{l}17.0 \\
14.7\end{array}$ & $\begin{array}{l}\text { Ford Ranger, Dodge Dakota } \\
\text { Ford F150, Chevrolet Silverado } 1500\end{array}$ \\
\hline Van & 18.1 & $\begin{array}{l}\text { Compact Van } \\
\text { Fullsize Van }\end{array}$ & $\begin{array}{l}18.3 \\
14.0\end{array}$ & $\begin{array}{l}\text { Honda Odyssey, Dodge Grand Caravan } \\
\text { Dodge Ram Van, Ford Club Waron E- } 150\end{array}$ \\
\hline
\end{tabular}


Table A-25: New Cars: Equilibrium price response to gasoline prices by segment

\begin{tabular}{|c|c|c|c|c|}
\hline Segment & Coef. (SE) & Subsegment & Coef. (SE) & Example \\
\hline \multirow[t]{2}{*}{$\begin{array}{l}\text { Compact Car } \\
(\text { avg. } \mathrm{MPG}=26.9)\end{array}$} & \multirow[t]{2}{*}{$\begin{array}{c}378^{* *} \\
(34)\end{array}$} & $\begin{array}{l}\text { Entry Compact Car } \\
\text { (avg. } \mathrm{MPG}=27.7 \text { ) }\end{array}$ & $\begin{array}{c}264^{* *} \\
(61)\end{array}$ & Hyundai Accent, Toyota Yaris \\
\hline & & $\begin{array}{l}\text { Premium Compact Car } \\
(\text { avg. } \mathrm{MPG}=26.8)\end{array}$ & $\begin{array}{c}390^{* *} \\
(33)\end{array}$ & Honda Civic, Ford Focus \\
\hline \multirow[t]{2}{*}{$\begin{array}{l}\text { Midsize Car } \\
(\text { avg. } \mathrm{MPG}=22.3)\end{array}$} & \multirow[t]{2}{*}{$\begin{array}{l}90 * \\
(41)\end{array}$} & $\begin{array}{l}\text { Entry Midsize Car } \\
(\text { avg. } \mathrm{MPG}=22.4)\end{array}$ & $\begin{array}{c}213^{* *} \\
(47)\end{array}$ & Pontiac G6, VW Jetta \\
\hline & & $\begin{array}{l}\text { Premium Midsize Car } \\
(\text { avg. } M P G=22.2)\end{array}$ & $(43)$ & Honda Accord, Ford Fusion, Nissan Altima \\
\hline \multirow[t]{4}{*}{$\begin{array}{l}\text { Luxury Car } \\
(\text { avg. } \mathrm{MPG}=19.6)\end{array}$} & \multirow[t]{4}{*}{$\begin{array}{c}-397^{* *} \\
(88)\end{array}$} & $\begin{array}{l}\text { Entry Luxury Car } \\
(\text { avg. } \mathrm{MPG}=20.1 \text { ) }\end{array}$ & $\begin{array}{l}-19 \\
(64)\end{array}$ & BMW 3-Series, Acura TSX \\
\hline & & $\begin{array}{l}\text { Mid Luxury Car } \\
(\text { avg. } M P G=19.1)\end{array}$ & $\begin{array}{l}-883^{*} *- \\
(118)\end{array}$ & BMW 5-Series, Volvo V70 \\
\hline & & $\begin{array}{l}\text { Premium Luxury Car } \\
(\text { avg. } M P G=18.0)\end{array}$ & $\begin{array}{l}-1672^{* *--} \\
(323)\end{array}$ & BMW 7 Series, Lexus LS Series \\
\hline & & $\begin{array}{l}\text { Luxury Sports Car } \\
(\text { avg. } M P G=17.0)\end{array}$ & $\begin{array}{c}-2026^{* *} \\
(411)\end{array}$ & BMW 6 Series, Mercedes SL-Class \\
\hline \multirow[t]{2}{*}{$\begin{array}{l}\text { Sporty Car } \\
(\text { avg. } \mathrm{MPG}=20.4)\end{array}$} & \multirow[t]{2}{*}{$\begin{array}{c}187^{* *} \\
(56)\end{array}$} & $\begin{array}{l}\text { Sporty Car } \\
(\text { avg. } \mathrm{MPG}=20.8)\end{array}$ & $\begin{array}{c}319^{* *} \\
(44)\end{array}$ & VW Golf GTI, Ford Mustang \\
\hline & & $\begin{array}{l}\text { Premium Sports Car } \\
(\text { avg. MPG=19.1) }\end{array}$ & $\begin{array}{l}-163 \\
(160)\end{array}$ & Chevrolet Corvette, Porsche 911 \\
\hline \multirow[t]{4}{*}{$\begin{array}{l}\text { SUV } \\
(\text { avg. } M P G=17.0)\end{array}$} & \multirow[t]{4}{*}{$\begin{array}{c}-83^{* *} \\
(21)\end{array}$} & $\begin{array}{l}\text { Entry SUV } \\
(\text { avg. } \mathrm{MPG}=19.4)\end{array}$ & $\begin{array}{c}295 * * \\
(19)\end{array}$ & Honda CRV, Ford Escape \\
\hline & & $\begin{array}{l}\text { (avg. } \mathrm{MPG}=16.4) \\
\text { MPdize SUV }\end{array}$ & $\begin{array}{c}-184{ }^{*} x^{-} \\
(43)\end{array}$ & Toyota 4Runner, Dodge Durango \\
\hline & & $\begin{array}{l}\text { Fullsize SUV } \\
(\text { avg. } M P G=14.0)\end{array}$ & $\begin{array}{l}-475 * * \\
(143)\end{array}$ & GMC Yukon, Toyota Sequoia \\
\hline & & $\begin{array}{l}\text { Luxury SUV } \\
\text { (avg. } \mathrm{MPG}=16.1 \text { ) }\end{array}$ & $\begin{array}{c}-459 * *- \\
(91)\end{array}$ & Acura MDX, Cadillac Escalade \\
\hline \multirow[t]{2}{*}{$\begin{array}{l}\text { Pickup } \\
(\text { avg. } \mathrm{MPG}=15.5)\end{array}$} & \multirow[t]{2}{*}{$\begin{array}{l}-127 \\
(77)\end{array}$} & $\begin{array}{l}\text { Compact Pickup } \\
(\text { avg. MPG }=17.0)\end{array}$ & $\begin{array}{c}37 \\
(58) \\
\end{array}$ & Ford Ranger, Dodge Dakota \\
\hline & & $\begin{array}{l}\text { Fullsize Pickup } \\
(\text { avg. } M P G=14.7)\end{array}$ & $\begin{array}{l}-215^{*} \\
(97)\end{array}$ & Ford F150, Chevrolet Silverado 1500 \\
\hline \multirow[t]{2}{*}{$\begin{array}{l}\text { Van } \\
(\text { avg. } \mathrm{MPG}=18.1)\end{array}$} & \multirow[t]{2}{*}{$\begin{array}{c}-87^{* *} \\
(28)\end{array}$} & $\begin{array}{l}\text { Compact Van } \\
(\text { avg. } \mathrm{MPG}=18.3)\end{array}$ & $\begin{array}{c}-101^{* *} \\
(29)\end{array}$ & Honda Odyssey, Dodge Grand Caravan \\
\hline & & $\begin{array}{l}\text { Fullsize Van } \\
(\text { avg. } \mathrm{MPG}=14.0)\end{array}$ & $\begin{array}{c}148 \\
(127)\end{array}$ & Dodge Ram Van, Ford Club Waron E-150 \\
\hline
\end{tabular}

* significant at $5 \% ; * *$ significant at $1 \% ;+$ significant at $10 \%$ level.

Full results are available upon request from the authors. 
Table A-26: Used Cars: Equilibrium price response to gasoline prices by segment

\begin{tabular}{|c|c|c|c|c|}
\hline Segment & Coef. (SE) & Subsegment & Coef. (SE) & Example \\
\hline \multirow[t]{2}{*}{$\begin{array}{l}\text { Compact Car } \\
(\text { avg. } \mathrm{MPG}=26.9)\end{array}$} & \multirow[t]{2}{*}{$\begin{array}{c}311^{* *} \\
(15)\end{array}$} & $\begin{array}{l}\text { Entry Compact Car } \\
\text { (avg. } \mathrm{MPG}=27.7 \text { ) }\end{array}$ & $\begin{array}{c}970^{* *} \\
(28)\end{array}$ & Hyundai Accent, Toyota Yaris \\
\hline & & $\begin{array}{l}\text { Premium Compact Car } \\
(\text { avg. } \mathrm{MPG}=26.8)\end{array}$ & $\begin{array}{l}270^{* *} \\
(17)\end{array}$ & Honda Civic, Ford Focus \\
\hline \multirow[t]{2}{*}{$\begin{array}{l}\text { Midsize Car } \\
(\text { avg. } \mathrm{MPG}=22.3)\end{array}$} & \multirow[t]{2}{*}{$\begin{array}{c}233^{* *} \\
(16)\end{array}$} & $\begin{array}{l}\text { Entry Midsize Car } \\
(\text { avg. } \mathrm{MPG}=22.4)\end{array}$ & $\begin{array}{c}742^{* *} \\
(28)\end{array}$ & Pontiac G6, VW Jetta \\
\hline & & $\begin{array}{l}\text { Premium Midsize Car } \\
(\text { avg. } M P G=22.2)\end{array}$ & $(14)$ & Honda Accord, Ford Fusion, Nissan Altima \\
\hline \multirow[t]{4}{*}{$\begin{array}{l}\text { Luxury Car } \\
(\text { avg. } \mathrm{MPG}=19.6)\end{array}$} & \multirow[t]{4}{*}{$\begin{array}{c}-261^{* *} \\
(41)\end{array}$} & $\begin{array}{l}\text { Entry Luxury Car } \\
\text { (avg. } \mathrm{MPG}=20.1 \text { ) }\end{array}$ & $\begin{array}{c}1087^{* *} \\
(44)\end{array}$ & BMW 3-Series, Acura TSX \\
\hline & & $\begin{array}{l}\text { Mid Luxury Car } \\
(\text { avg. } M P G=19.1)\end{array}$ & $\begin{array}{c}-629 * *- \\
(58)\end{array}$ & BMW 5-Series, Volvo V70 \\
\hline & & $\begin{array}{l}\text { Premium Luxury Car } \\
(\text { avg. } M P G=18.0)\end{array}$ & $\begin{array}{c}-6861^{* *} \\
(119)\end{array}$ & BMW 7 Series, Lexus LS Series \\
\hline & & $\begin{array}{l}\text { Luxury Sports Car } \\
(\text { avg. } M P G=17.0)\end{array}$ & $\begin{array}{c}-4907 * * \\
(309)\end{array}$ & BMW 6 Series, Mercedes SL-Class \\
\hline \multirow[t]{2}{*}{$\begin{array}{l}\text { Sporty Car } \\
(\text { avg. } \mathrm{MPG}=20.4)\end{array}$} & \multirow[t]{2}{*}{$\begin{array}{c}329 * * \\
(30)\end{array}$} & $\begin{array}{l}\text { Sporty Car } \\
(\text { avg. } \mathrm{MPG}=20.8)\end{array}$ & $\begin{array}{c}1243^{* *} \\
(50)\end{array}$ & VW Golf GTI, Ford Mustang \\
\hline & & $\begin{array}{l}\text { Premium Sports Car } \\
(\text { avg. } M P G=19.1)\end{array}$ & $\begin{array}{c}-2392^{* *} \\
(86)\end{array}$ & Chevrolet Corvette, Porsche 911 \\
\hline \multirow[t]{4}{*}{$\begin{array}{l}\text { SUV } \\
(\text { avg. } M P G=17.0)\end{array}$} & \multirow[t]{4}{*}{$\begin{array}{c}-281^{* *} \\
(28)\end{array}$} & $\begin{array}{l}\text { Entry SUV } \\
(\text { avg. } \mathrm{MPG}=19.4)\end{array}$ & $\begin{array}{c}1748^{* *} \\
(52)\end{array}$ & Honda CRV, Ford Escape \\
\hline & & $\begin{array}{l}\text { (avg. } \mathrm{MPG}=16.4) \\
\text { MPdize SUV }\end{array}$ & $\begin{array}{l}-119 \\
(75)\end{array}$ & Toyota 4Runner, Dodge Durango \\
\hline & & $\begin{array}{l}\text { Fullsize SUV } \\
(\text { avg. } M P G=14.0)\end{array}$ & $\begin{array}{c}-2101^{* *} \\
(120)\end{array}$ & GMC Yukon, Toyota Sequoia \\
\hline & & $\begin{array}{l}\text { Luxury SUV } \\
(\text { avg. } \mathrm{MPG}=16.1)\end{array}$ & $\begin{array}{c}-3806^{* *} \\
(105)\end{array}$ & Acura MDX, Cadillac Escalade \\
\hline \multirow[t]{2}{*}{$\begin{array}{l}\text { Pickup } \\
(\text { avg. } \mathrm{MPG}=15.5)\end{array}$} & \multirow[t]{2}{*}{$\begin{array}{c}-81^{* *} \\
(24)\end{array}$} & $\begin{array}{l}\text { Compact Pickup } \\
(\text { avg. MPG }=17.0)\end{array}$ & $\begin{array}{c}942^{* *} \\
(26)\end{array}$ & Ford Ranger, Dodge Dakota \\
\hline & & $\begin{array}{l}\text { Fullsize Pickup } \\
(\text { avg. } M P G=14.7)\end{array}$ & $\begin{array}{c}-711^{* *} \\
(32)\end{array}$ & Ford F150, Chevrolet Silverado 1500 \\
\hline \multirow[t]{2}{*}{$\begin{array}{l}\text { Van } \\
(\text { avg. } \mathrm{MPG}=18.1)\end{array}$} & \multirow[t]{2}{*}{$\begin{array}{c}150^{* *} \\
(29)\end{array}$} & $\begin{array}{l}\text { Compact Van } \\
(\text { avg. } \mathrm{MPG}=18.3)\end{array}$ & $\begin{array}{c}110^{* *} \\
(28)\end{array}$ & Honda Odyssey, Dodge Grand Caravan \\
\hline & & $\begin{array}{l}\text { Fullsize Van } \\
(\text { avg. } \mathrm{MPG}=14.0)\end{array}$ & $\begin{array}{c}1477^{* *} \\
(81)\end{array}$ & Dodge Ram Van, Ford Club Waron E-150 \\
\hline
\end{tabular}

${ }^{*}$ significant at $5 \% ; * *$ significant at $1 \% ;+$ significant at $10 \%$ level.

Full results are available upon request from the authors. 
Table A-27: New Cars: Sales response to gasoline prices by segment

\begin{tabular}{|c|c|c|c|c|}
\hline Segment & $\begin{array}{l}\% \text { Sales } \\
\text { Change }\end{array}$ & Subsegment & $\begin{array}{l}\% \text { Sales } \\
\text { Change }\end{array}$ & Example \\
\hline \multirow[t]{2}{*}{$\begin{array}{l}\text { Compact Car } \\
(\text { avg. } \mathrm{MPG}=26.9)\end{array}$} & \multirow[t]{2}{*}{$10.2 \%$} & $\begin{array}{l}\text { Entry Compact Car } \\
\text { (avg. } \mathrm{MPG}=27.7 \text { ) }\end{array}$ & $49.1 \% * *$ & Hyundai Accent, Toyota Yaris \\
\hline & & $\begin{array}{l}\text { Premium Compact Car } \\
(\text { avg. } \mathrm{MPG}=26.8)\end{array}$ & $6.8 \% *$ & Honda Civic, Ford Focus \\
\hline \multirow[t]{2}{*}{$\begin{array}{l}\text { Midsize Car } \\
(\text { avg. } \mathrm{MPG}=22.3)\end{array}$} & \multirow[t]{2}{*}{$-3.7 \%$} & $\begin{array}{l}\text { Entry Midsize Car } \\
(\text { avg. } \mathrm{MPG}=22.4)\end{array}$ & $8.3 \%+$ & Pontiac G6, VW Jetta \\
\hline & & $\begin{array}{l}\text { Premium Midsize Car } \\
(\text { avg. } M P G=22.2)\end{array}$ & $-7.1 \% *$ & Honda Accord, Ford Fusion, Nissan Altima \\
\hline \multirow[t]{4}{*}{$\begin{array}{l}\text { Luxury Car } \\
(\text { avg. } \mathrm{MPG}=19.6)\end{array}$} & \multirow[t]{4}{*}{$-6.4 \%$} & $\begin{array}{l}\text { Entry Luxury Car } \\
(\text { avg. } \mathrm{MPG}=20.1 \text { ) }\end{array}$ & $-3.6 \%$ & BMW 3-Series, Acura TSX \\
\hline & & $\begin{array}{l}\text { Mid Luxury Car } \\
(\text { avg. } M P G=19.1)\end{array}$ & $-7.4 \%{ }^{*}$ & BMW 5-Series, Volvo V70 \\
\hline & & $\begin{array}{l}\text { Premium Luxury Car } \\
(\text { avg. } M P G=18.0)\end{array}$ & $-20.5 \% * *-$ & $\mathrm{BM} \overline{\mathrm{W}} 7$ Series, Lexus LS Series \\
\hline & & $\begin{array}{l}\text { Luxury Sports Car } \\
(\text { avg. } \mathrm{MPG}=17.0)\end{array}$ & $-14.6 \% * *$ & BMW 6 Series, Mercedes SL-Class \\
\hline \multirow[t]{2}{*}{$\begin{array}{l}\text { Sporty Car } \\
(\text { avg. } \mathrm{MPG}=20.4)\end{array}$} & \multirow[t]{2}{*}{$-11.1 \%$} & $\begin{array}{l}\text { Sporty Car } \\
(\text { avg. } \mathrm{MPG}=20.8)\end{array}$ & $-16.7 \% * *$ & VW Golf GTI, Ford Mustang \\
\hline & & $\begin{array}{l}\text { Premium Sports Car } \\
(\text { avg. } M P G=19.1)\end{array}$ & $8.5 \% *^{-}$ & Chevrolet Corvette, Porsche 911 \\
\hline \multirow[t]{4}{*}{$\begin{array}{l}\text { SUV } \\
\text { (avg. } M P G=17.0)\end{array}$} & \multirow[t]{4}{*}{$-21.5 \%$} & $\begin{array}{l}\text { Entry SUV } \\
(\text { avg. } \mathrm{MPG}=19.4)\end{array}$ & $-13.3 \% * *$ & Honda CRV, Ford Escape \\
\hline & & (avg. MPG=16.4) & $-22.3 \% * *$ & Toyota 4 Runner, Dodge Durango \\
\hline & & $\begin{array}{l}\text { Fullsize SUV } \\
\text { (avg. } M P G=14.0)\end{array}$ & $-39.4 \% * *-$ & GMC Yukon, Toyota Sequoia \\
\hline & & $\begin{array}{l}\text { Luxury SUV } \\
(\text { avg. } M P G=16.1)\end{array}$ & $-14.9 \% * *$ & Acura MDX, Cadillac Escalade \\
\hline \multirow[t]{2}{*}{$\begin{array}{l}\text { Pickup } \\
(\text { avg. } \mathrm{MPG}=15.5)\end{array}$} & \multirow[t]{2}{*}{$-24.0 \%$} & $\begin{array}{l}\text { Compact Pickup } \\
(\text { avg. } \mathrm{MPG}=17.0)\end{array}$ & $-23.3 \% * *$ & Ford Ranger, Dodge Dakota \\
\hline & & $\begin{array}{l}\text { Fullsize Pickup } \\
(\text { avg. } M P G=14.7)\end{array}$ & $-24.2 \% * *$ & Ford F150, Chevrolet Silverado 1500 \\
\hline \multirow[t]{2}{*}{$\begin{array}{l}\text { Van } \\
(\text { avg. } M P G=18.1)\end{array}$} & \multirow[t]{2}{*}{$-17.5 \%$} & $\begin{array}{l}\text { Compact Van } \\
(\text { avg. } \mathrm{MPG}=18.3)\end{array}$ & $-15.4 \% * *$ & Honda Odyssey, Dodge Grand Caravan \\
\hline & & $\begin{array}{l}\text { Fullsize Vang. } M P G=14.0)\end{array}$ & $-26.1 \% * *$ & Dodge Ram Van, Ford Club Waron E-150 \\
\hline
\end{tabular}

${ }^{*}$ significant at $5 \% ;{ }^{* *}$ significant at $1 \% ;+$ significant at $10 \%$ level.

Full results are available upon request from the authors. 
Table A-28: Used Cars: Sales response to gasoline prices by segment

\begin{tabular}{|c|c|c|c|c|}
\hline Segment & $\begin{array}{l}\% \text { Sales } \\
\text { Change }\end{array}$ & Subsegment & $\begin{array}{l}\% \text { Sales } \\
\text { Change }\end{array}$ & Example \\
\hline \multirow[t]{2}{*}{$\begin{array}{l}\text { Compact Car } \\
(\text { avg. } \mathrm{MPG}=26.9)\end{array}$} & \multirow[t]{2}{*}{$1.6 \%$} & $\begin{array}{l}\text { Entry Compact Car } \\
(\text { avg. } \mathrm{MPG}=27.7)\end{array}$ & $-10.0 \%$ & Hyundai Accent, Toyota Yaris \\
\hline & & $\begin{array}{l}\text { Premium Compact Car } \\
(\text { avg. } \mathrm{MPG}=26.8)\end{array}$ & $2.2 \%$ & Honda Civic, Ford Focus \\
\hline \multirow[t]{2}{*}{$\begin{array}{l}\text { Midsize Car } \\
(\text { avg. } \mathrm{MPG}=22.3)\end{array}$} & \multirow[t]{2}{*}{$-0.4 \%$} & $\begin{array}{l}\text { Entry Midsize Car } \\
(\text { avg. } \mathrm{MPG}=22.4)\end{array}$ & $-4.0 \%$ & Pontiac G6, VW Jetta \\
\hline & & $\begin{array}{l}\text { Premium Midsize Car } \\
(\text { avg. } \mathrm{MPG}=22.2)\end{array}$ & $-0.7 \%$ & Honda Accord, Ford Fusion, Nissan Altima \\
\hline \multirow[t]{4}{*}{$\begin{array}{l}\text { Luxury Car } \\
(\text { avg. } \mathrm{MPG}=19.6)\end{array}$} & \multirow[t]{4}{*}{$-6.7 \% * *$} & $\begin{array}{l}\text { Entry Luxury Car } \\
\text { (avg. } \mathrm{MPG}=20.1 \text { ) }\end{array}$ & $-2.1 \%$ & BMW 3-Series, Acura TSX \\
\hline & & $\begin{array}{l}\text { Mid Luxury Car } \\
(\text { avg. MPG=19.1) }\end{array}$ & $-12.5 \% * *$ & BMW 5-Series, Volvo V70 \\
\hline & & $\begin{array}{l}\text { Premium Luxury Car } \\
\text { (avg. } M P G=18.0)\end{array}$ & $-11.4 \%+$ & BMW 7 Series, Lexus LS Series \\
\hline & & $\begin{array}{l}\text { Luxury Sports Car } \\
(\text { avg. } \mathrm{MPG}=17.0)\end{array}$ & $5.0 \%$ & BMW 6 Series, Mercedes SL-Class \\
\hline \multirow[t]{2}{*}{$\begin{array}{l}\text { Sporty Car } \\
(\text { avg. } \mathrm{MPG}=20.4)\end{array}$} & \multirow[t]{2}{*}{$-11.8 \% * *$} & $\begin{array}{l}\text { Sporty Car } \\
(\text { avg. } \mathrm{MPG}=20.8)\end{array}$ & $-14.4 \% * *$ & VW Golf GTI, Ford Mustang \\
\hline & & $\begin{array}{l}\text { Premium Sports Car } \\
(\text { avg. } \mathrm{MPG}=19.1)\end{array}$ & $7.7 \%$ & Chevrolet Corvette, Porsche 911 \\
\hline \multirow[t]{4}{*}{$\begin{array}{l}\text { SUV } \\
(\text { avg. } \mathrm{MPG}=17.0)\end{array}$} & \multirow[t]{4}{*}{$-11.0 \% * *$} & $\begin{array}{l}\text { Entry SUV } \\
(\text { avg. } \mathrm{MPG}=19.4)\end{array}$ & $1.0 \%$ & Honda CRV, Ford Escape \\
\hline & & $\begin{array}{l}\text { Midsize SUV. } M P G=16.4) \\
\text { avg }\end{array}$ & $-13.6 \% * *$ & Toyota 4Runner, Dodge Durango \\
\hline & & $\begin{array}{l}\text { (avg. } \mathrm{MPG}=14.0) \\
\text { Fullsize SUV }\end{array}$ & $-20.4 \% * *$ & GMC Yukon, Toyota Sequoia \\
\hline & & $\begin{array}{l}\text { Luxury SUV } \\
\text { (avg. } \mathrm{MPG}=16.1)\end{array}$ & $0.0 \%$ & Acura MDX, Cadillac Escalade \\
\hline \multirow[t]{2}{*}{$\begin{array}{l}\text { Pickup } \\
(\text { avg. } \mathrm{MPG}=15.5)\end{array}$} & \multirow[t]{2}{*}{$-12.1 \% * *$} & $\begin{array}{l}\text { Compact Pickup } \\
(\text { avg. } \mathrm{MPG}=17.0)\end{array}$ & $-9.7 \% * *$ & Ford Ranger, Dodge Dakota \\
\hline & & $\begin{array}{l}\text { Fullsize Pickup } \\
\text { (avg. MPG=14.7) }\end{array}$ & $-13.7 \% * *$ & Ford F150, Chevrolet Silverado 1500 \\
\hline \multirow[t]{2}{*}{$\begin{array}{l}\text { Van } \\
(\text { avg. } M P G=18.1)\end{array}$} & \multirow[t]{2}{*}{$-10.3 \% * *$} & $\begin{array}{l}\text { Compact Van } \\
(\text { avg. } \mathrm{MPG}=18.3 \text { ) }\end{array}$ & $-10.2 \% * *$ & Honda Odyssey, Dodge Grand Caravan \\
\hline & & $\begin{array}{l}\text { Fullsize Van } \\
(\text { avg. } M P G=14.0)\end{array}$ & $5.6 \%$ & Dodge Ram Van, Ford Club Waron E- 150 \\
\hline
\end{tabular}

* significant at $5 \%$;* significant at $1 \%$; significant at $10 \%$ level.

Full results are available upon request from the authors. 
Figure A-1: Annual share of new vehicles offered by bin, Asian manufacturers

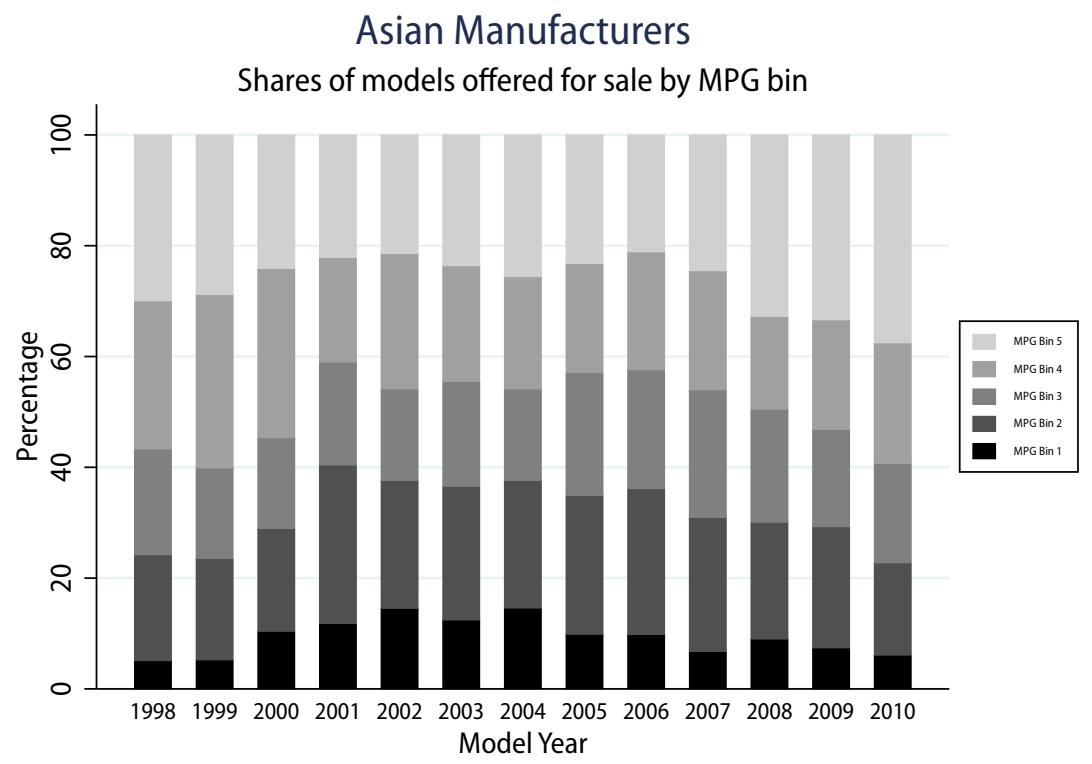

Figure A-2: Annual share of new vehicles offered by bin, European manufacturers

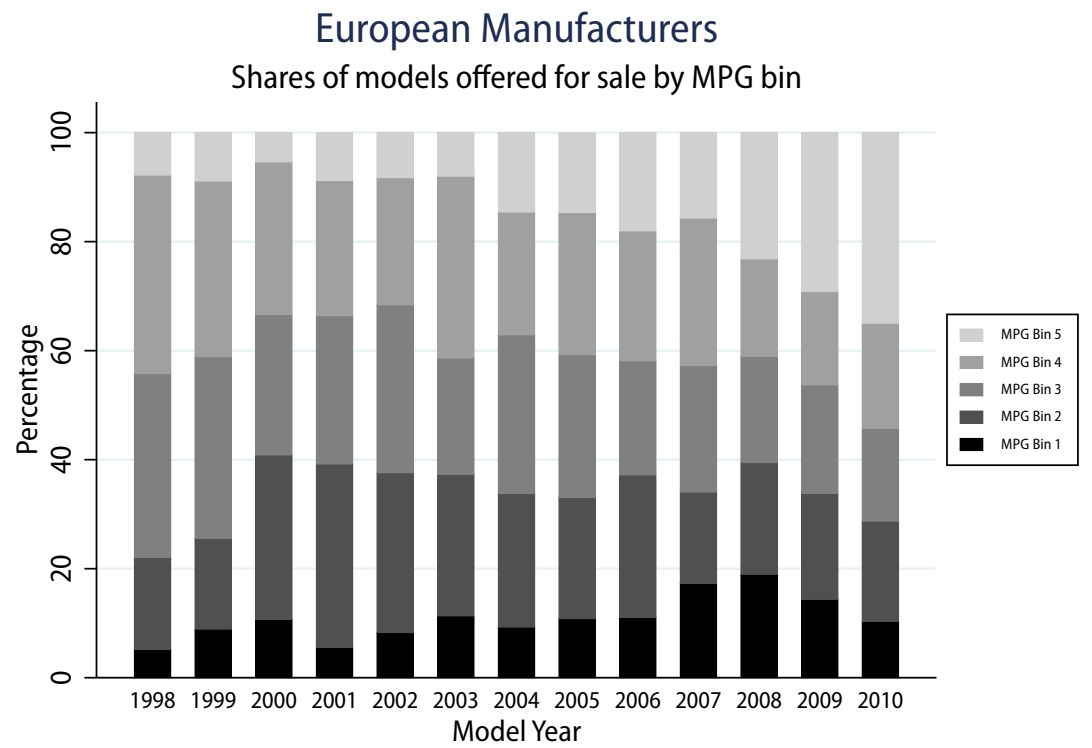


Figure A-3: Annual share of new vehicles offered by bin, U.S. manufacturers

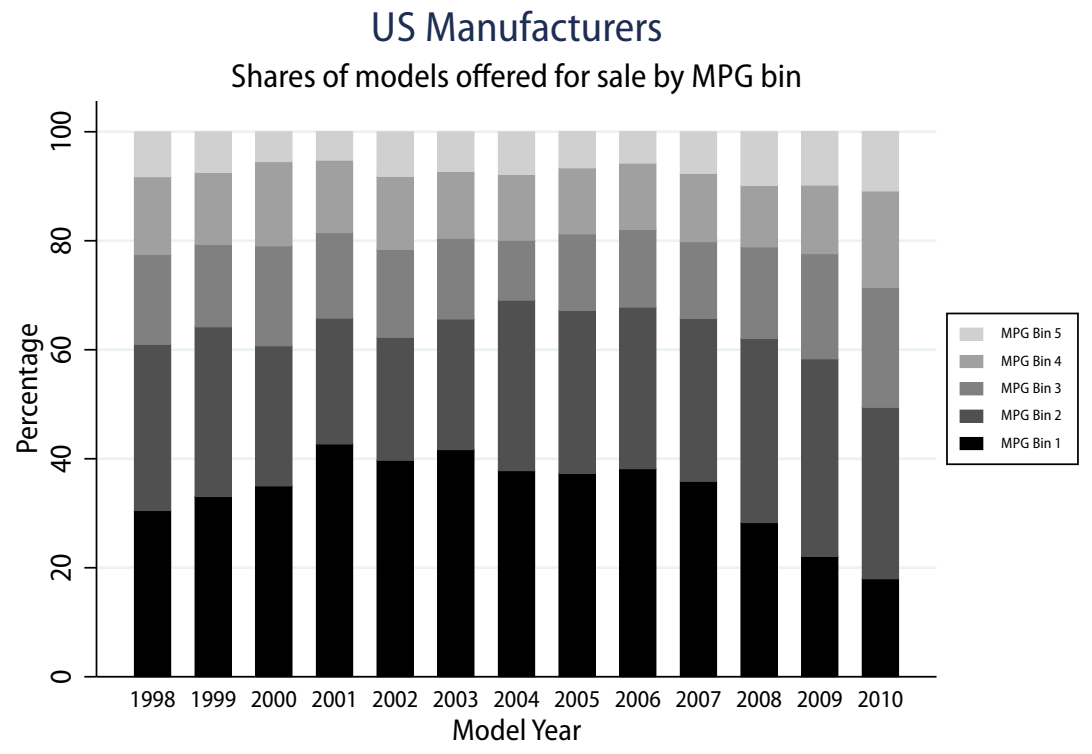

Appendix-22 